\title{
Histamine, Histamine Receptors, and their Role in Immunomodulation: An Updated Systematic Review
}

\author{
Mohammad Shahid ${ }^{*}, 1$, Trivendra Tripathi ${ }^{2}$, Farrukh Sobia ${ }^{1}$, Shagufta Moin ${ }^{2}$, Mashiatullah Siddiqui ${ }^{2}$ \\ and Rahat Ali Khan ${ }^{3}$
}

${ }^{I}$ Section of Immunology and Molecular Biology, Department of Microbiology, ${ }^{2}$ Department of Biochemistry, and
${ }^{3}$ Department of Pharmacology, Faculty of Medicine, Jawaharlal Nehru Medical College \& Hospital, Aligarh Muslim
University, Aligarh-202002, U.P., India

\begin{abstract}
Histamine, a biological amine, is considered as a principle mediator of many pathological processes regulating several essential events in allergies and autoimmune diseases. It stimulates different biological activities through differential expression of four types of histamine receptors (H1R, H2R, H3R and H4R) on secretion by effector cells (mast cells and basophils) through various immunological or non-immunological stimuli. Since H4R has been discovered very recently and there is paucity of comprehensive literature covering new histamine receptors, their antagonists/agonists, and role in immune regulation and immunomodulation, we tried to update the current aspects and fill the gap in existing literature. This review will highlight the biological and pharmacological characterization of histamine, histamine receptors, their antagonists/agonists, and implications in immune regulation and immunomodulation.
\end{abstract}

Keywords: Histamine, histamine receptors, H4-receptor, antagonists, agonists, immunomodulation.

\section{INTRODUCTION}

In historical evolution, histamine (biogenic amine) is probably one of the most important phlogistic ancient mediator, and even one of the most intensely studied molecules in biological systems which have been using histamine, catecholamines and other chemical mediators to communicate among cells [1]. Histamine was synthesized in 1907 and characterized in 1910 as a substance ("beta-1") [2], owing to its significant competence to constrict guinea pig ileum, and its cogent vasodepressor action. However, it took 17 years to demonstrate its presence in normal tissues [3]. The relation between histamine and anaphylactic reactions was made rapidly in 1929, and was identified as a mediator of anaphylactic reactions in $1932[4,5]$, whereas its connection to mast cells was not made until 1952 [6], and also its connection to basophils in 1972 [7]. The search for compounds being potent to neutralize the pathological effects of histamine began at the Pasteur Institute in Paris during the 1930s, and these compounds were found to partially block the effects of histamine based on the ethylenediamine structure. The first antihistamine compound was the adrenolytic benzodioxan, piperoxan $(933 \mathrm{~F})$, reported by Ungar, Parrot and Bovet in 1937 and was shown to block the effect of histamine on the guinea-pig ileum [8]. It followed shortly by the report of Bovet and Staub [9] that structurally related to aryl ethers such as the thymol ether (929F) [8]. The latter antihistamine compound proved to be highly toxic for clinical development; however, the replacement of ether oxygen by an amino group led to the search of aniline ethylene diamine

*Address correspondence to this author at the Department of Microbiology, JN Medical College \& Hospital, Aligarh Muslim University, Aligarh-202 002, U.P., India; Tel: +91-571-2720382; Fax: +91-571-2720382;

E-mail: shahidsahar@yahoo.co.in; drmohdshahid123@yahoo.com derivatives. For this noble research on antihistamines and curare, Bovet was awarded the Nobel Prize in 1957 [8]. It was being documented that histamine played an important role as a mediator of allergic reactions indicated by a series of compounds with antihistamine activity which protected guinea pigs from anaphylaxis. However, the clinical use of these compounds in humans was precluded due to their toxicity [9]. The first antihistamine, Antergan ${ }^{\mathrm{TM}}$ (phenbenzamine, RP 2339) was being used in humans [10], but this compound was subsequently replaced by Neoantergan ${ }^{\mathrm{TM}}$ (mepyramine, pyrilamine, RP 2786), which is still in use to counteract the uncomfortable effects of histamine release in the skin. Many other antihistamines such as diphenhydramine (Benadryl ${ }^{\mathrm{TM}}$ ), tripelennamine, chlorpheniramine and promethazine are also used in similar manner to counteract the adverse effects of histamine [8]. Subsequently, after 1945 , these antihistamines were widely used in the treatment of various allergic diseases such as hay fever, urticaria, and allergic rhinitis. However, the side effects were not uncommon and the sedation was a drawback to their use. A very few side effects were put to their good use; therefore, some antihistamines such as cyclizine (Marzine ${ }^{\mathrm{TM}}$ ) and diphenhydramine in the form of its 8-chlorotheophyllinate (Drama$\operatorname{mine}^{\mathrm{TM}}$ ) are being used as an antiemetics for travel sickness [8]. By 1950 there were only 20 compounds clinically available to block the effects of histamine [1], but advances in histamine receptors (HRs) ligands have ever attracted many researchers for pharmaceutical developments and are still highly topical [11].

Histamine (2-(imidazol-4-yl) ethylamine) is one of the monoamines and was coined after the Greek word for tissue histos, with the broadest spectrum of activities in various physiological and pathological conditions including the cell proliferation, differentiation, hematopoiesis, embryonic development, regeneration, wound healing, aminergic neuro- 
transmission and numerous brain functions (sleep/nociception, food intake and aggressive behavior), secretion of pituitary hormones, regulation of gastrointestinal and circulatory functions, cardiovascular system (vasodilatation and blood pressure reduction), as well as inflammatory reactions, modulation of the immune response, energy of endocrine and homeostasis [1, 12-18]. It is being documented by several studies which highlighted the evidence of histamine that it elicits immune-modulatory and pro-inflammatory effects by the differential expression of histamine receptors (H1R, $\mathrm{H} 2 \mathrm{R}, \mathrm{H} 3 \mathrm{R}$, and H4R) that is easily modulated the diverse effects of histamine on immune regulation and distinct intracellular signals. All these four receptors are members of the 7-transmembrane (heptahelical) spanning family of receptors, are G protein-coupled (GPCR), are expressed on various histamine responsive target tissues and cells and suggest an important critical role of histamine in immunomodulation and allergic diseases [1, 8, 11-14].

In the present review, we will discuss biology of histamine including synthesis, regulation and metabolism; histamine receptors including $\mathrm{H} 1-, \mathrm{H} 2-, \mathrm{H} 3-$, and H4-receptors and their cellular distribution, functional characterization, structural biology, and signaling mechanisms; non-classical histamine-binding sites such as cytochrome P450; and histamine transporters; as well as immune regulation by histamine in immunomodulation and allergic inflammation; effects of histamine in immune cells in respect to allergic diseases; implication of histamine on cytokines production; significance of histamine in autoimmunity and allergic diseases and also in malignancies; and finally the relation of histamine-cytokine during hematopoiesis.

\section{BIOLOGY OF HISTAMINE}

Histamine exhibits two main important basic functionalities such as primary aliphatic amine $\left(\mathrm{pK}_{\mathrm{a} 1} 9.4\right)$ and imidazole $\left(\mathrm{pK}_{\mathrm{a} 2}\right.$ 5.8). These make the monocation with different tautomers; the preferred form at physiologic $\mathrm{pH}$ value $(96 \%)$ with a minor dicationic fraction $(3 \%)$ and a very small amount of the neutral form [19]. The nomenclature for histamine positions may be highly significant for histamine biology including synthesis, regulation, metabolism, and also histamine derivatives (Fig. 1).

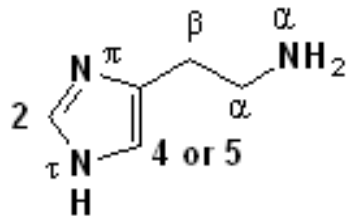

Fig. (1). Specific nomenclature for histamine positions.

\section{A. Synthesis of Histamine}

Histamine was first identified as an autocoid having potent vasoactive properties. It is a low molecular weight amine synthesized from L-histidine exclusively by Lhistidine decarboxylase (HDC) (E.C. 4.1.1.22 or E.C. 4.1.1.26), which is dependent on the cofactor pyridoxal-5'phosphate to a putative binding site (TFNPSKW) on the protein. Histamine cannot be generated by another enzymatic pathway [8, 14]. Histidine decarboxylase (HDC) is an enzyme that is expressed in various cells through out the body, including central nervous system, neurons, gastric-mucosa, parietal cells, mast cells( $\sim 3 \mathrm{pg} / \mathrm{cell}$ histamine), and basophils( $\sim 1 \mathrm{pg} /$ cell histamine $)$. Histamine has an important role in human health, and exerting its diverse biologic effects by 4 types of receptors [1, 13, 20-22]. Histamine is also produced by enterochromaffin-like cells (ECL) in the stomach and plays an important role in secretion of gastric acid [14]. Only basophils and mast cells can store the amine in specific granules, in the hematopoietic system, where histamine is closely associated with anionic proteoglycans heparin (in mast cells) and chondroitin-4-sulfate (in basophils). In this specific form, histamine can be released in large amounts during degranulation in response to various immunological (immunoglobulin E, or cytokines) or non-immunological (compound 48/80, calcium ionophore, mastoparin, substance $\mathrm{P}$, opioids, or hypo-osmolar solutions) stimuli [14]. Histamine synthesis in Golgi apparatus can be inhibited by $\alpha$ fluoromethylhistidin [23].

Recently, many myeloid and lymphoid cell types that do not store histamine show more HDC activity and are capable of synthesis of high amounts of histamine [24]. This so called "neo synthesized histamine," has been shown in various cells, including hematopoietic progenitors, macrophages, neutrophils, platelets, dendritic cells (DCs) and T cells [14, 25-28]. Histamine synthesis in non-mast cells was first confirmed using $W / W^{V}$ mice, which genetically lack mature mast cells, upon stimulation with a phorbol ester [29]. HDC activity is demonstrated in vitro through cytokines, such as IL-1, IL-3, IL-12, IL- 18, GM-CSF, macrophage-colony stimulating factor, TNF- $\alpha$, and calcium ionophore [30, 31]. Histidine decarboxylase (HDC) activity has been modulated in conditions such as LPS stimulation, inflammation, infection, and graft rejection, in vivo [32].

It is being demonstrated that the generation of HDCknockout mice provides histamine-free system and it is more beneficial to study the role of endogenous histamine in a broad range of normal and disease processes. Such mice demonstrate diminished numbers of mast cells and significantly decreased granule content, which suggests that histamine might affect the production of mast cell granule proteins [33]. In a recent study, interleukin-3 (IL-3)-dependent bone marrow derived mast cells (BMMCs) have been found to be activated by certain immunoglobulin-E ( $\operatorname{IgE}$ ) clones in absence of specific antigen, leading to their survival, cytokine secretion, histamine production, adhesion, and migration [34]. In addition to this study, Tanaka et al. [35] has shown a drastic and transient induction of HDC $(\sim 200$-fold in activity) in BMMCs stimulated by $\operatorname{IgE}$ alone, which was found much higher than that upon antigen stimulation. Thus, this induction resulted in the increase in stored histamine. Another study suggested that the anti-apoptic effects of monomeric IgE on BMMCs were mediated by interleukin-3 (IL-3) in an autocrine fashion [36]. Although Schneider et al. [30] found the potential role of IL-3 to induce HDC in bone marrow cells, it is clearly indicated that monomeric IgEinduced histamine synthesis may not be mediated through IL-3 [36]. Since stimulation of histamine synthesis occurs upon IgE-mediated antigen induction, and this remains controversial if these two modes of FceRI activation share a common signal transduction pathway. However, many recent studies have demonstrated the qualitative differences between both modes: such as monomeric IgE-induced $\mathrm{Ca}^{2+}$ influx is mediated by a distinct channel from that activated 
upon antigen stimulation [37], and protein kinase C beta-II (PKCBII) plays a significant role in monomeric IgE-induced histamine synthesis in mast cells, but not upon antigen stimulation [38]. Since, only small levels of increase in histamine synthesis were found by monomeric IgE both in purified rat peritoneal mast cells and in vitro maturated BMMCs, inducing effects of monomeric IgE on mast cells may be limited to immature mast cells [37]. However, Tanaka and Ichikawa [39] has suggested that monomeric IgE-induced histamine synthesis exacerbates the symptoms of chronic allergy, while drastic increases in the levels of serum IgE are often observed in such diseases.

\section{B. Regulation of Histamine}

Histamine is synthesized only by HDC enzyme. Therefore, histamine regulation is dependent on the gene of HDC enzyme, which is expressed in the cells throughout the body. It has been shown that complementary deoxyribonucleic acids (cDNAs) of HDC enzyme have been isolated from mouse mastocytoma, fetal rat liver, erythroleukemia cells and human basophil leukemia cells. Based on structural studies, mouse and human genes are composed of 12 exons spanning nearly $24 \mathrm{~kb}$. The $2.4 \mathrm{~kb}$ single transcript is produced by mouse gene, whereas two splice variants of $3.4 \mathrm{~kb}$ and $2.4 \mathrm{~kb}$ exist in humans, and latter encode the functional HDC [40]. HDC gene is found on chromosome 2 in mice and chromosome 15 in human and their expression is controlled by lineage-specific transcription factors. These factors interact with a promoter region consisting of GC box, four GATA consensus sequences, a c-Myb-binding motif and four CACC boxes [41]. It has been demonstrated in several studies that the HDC transcription is regulated by various factors in gastric cancer cells such as gastrin, oxidative stress and phorbol 12-myristate 13-acetate (PMA), through a Rasindependent, Raf-dependent mechanism, MAP kinase/ERK and a protein kinase $\mathrm{C}(\mathrm{PKC})$ pathways functioning on three overlapping cisacting elements (GASRE 1, GAS-RE 2 and GAS-RE3) known as gastrin response elements $[42,43]$. The negative control on HDC expression in gastric epithelial cell line is exerted by expression of the transcription factors GATA-4 and GATA-6 [44]. It is well known that the expression of HDC in basophils and mast cells seems to be a consequence of the state of $\mathrm{CpG}$ methylation in the promoter region [45]. Many studies on the mast cell line HMC1 and the pluripotent hematopoietic cell line UT7D1 have demonstrated that HDC-gene expression is subject to posttranscriptional control. Therefore, the chromosomal configuration and methylation of the HDC-promoter is likely to account for its cell-specific expression [46, 47]. It has also been reported that PMA stimulates a strong increase in HDC activity in UT7D1, which is affected by actinomycin D, and that is not paralleled by enhanced HDC mRNA expression. Similar effect was noted in cell lines (HEL and CMK) with megakaryocyte/basophil differentiation potential [48]. In addition to this effect, a mechanism that accounts for the strong enhancement of HDC activity in ECL cells in response to gastrin is explained by a translation control of HDC expression [49]. Two essential mechanisms of translational control have been explained in hematopoietic cells: (i) a rapamycin dependent pathaway that is linked to phosphoinositide 3-kinase (PI3K), FRAP/mTOR and phosphorylation/dephosphorylation of repressor of translation 4E- binding protein (4E-Bps) and (ii) ERK- and p38-dependent pathway that control the 4E-BP expression by the induction of Egr-1 [50]. The multiple carboxy-truncated isoforms are formed due to post-translational processing of HDC gene; the gene is initially translated $73-74 \mathrm{kDa}$ protein in mammals, and originally it was assumed that enzymes purified from native sources corresponded to a dimer of two processed isoforms of 53 and $55 \mathrm{kDa}$. According to Fleming and Wang [51], the biosynthesis of histamine involves primarily the $55 \mathrm{kDa}$ isoform and it is being acknowledged that many other isoforms generated from $74 \mathrm{kDa}$ primary translation product can also be active. It is also being documented that enhancing the histidine decarboxylase activity might cause reduction in messenger RNA (mRNA) degradation by amino acid carboxyl-terminal PEST domains [52]. Here is a need to completely understand the negative feed back regulation of histidine decarboxylase activity that differs from one cell type to another. This activity has been shown in AGS-B cells that over expression of the HDC protein inhibited histidine decarboxylase promoter activity by down regulation of ERK signals [53].

However, in gastrin-stimulated ECL cells, this type of feed back mechanism was not observed. It was also demonstrated that in the hematopoietic cells, as well as in the stomach, negative feed back signals could be produced through high cytosolic histamine concentration [50]. Histamine reuptake mechanism comparable to that of the other aminergic neurotransmitters has not been observed [54].

\section{Metabolism of Histamine}

It is noteworthy that only a small amount of released histamine ( 2 to $3 \%$ ) is excreted unchanged. The remaining histamine (more than 97\%) is controlled via two major pathways for the metabolizing enzymes: histamine $N^{\tau}$ methyltransferase (HMT) (EC 2.1.1.8) and diamine oxidase (DAO) (EC1.4.3.6) before excretion $[23,55]$. Histamine $N^{\tau}$ methyltransferase metabolizes the majority of histamine (50 to $80 \%$ ) to $N$-methyl histamine, which is further metabolized to the primary urinary metabolite $M$-methylimidazole acetic acid by monoamine oxidase. Diamine oxidase metabolizes the histamine (15 to $30 \%$ ) to imidazole acetic acid [20]. The study of the former pathway was greatly facilitated by the availability of a potent and highly specific inhibitor of diamine oxidase, aminoguanidine. HMT appears to be the most important enzyme contributing to the degradation of histamine in the airways, because blockers of HMT (such as SKF 91488) increase the bronchoconstricting action of histamine in vitro and in vivo, whereas diamine oxidase inhibition remained uneffected [56]. HMT is expressed in airway epithelial cells and may therefore be responsible for the local metabolism of histamine released from airway mast cells. Mechanical removal of airway epithelium enhances the bronchoconstriction response to histamine in vitro [57-59]; this might be the result, in part, of loss of the metabolizing enzyme. Furthermore, experimental viral infections resulted in reduced epithelial HMT activity in association with increased responsiveness to inhaled histamine [60]. The halflife of pharmacologically active doses of histamine is less than $10 \mathrm{~s}$ in the rat and 20-30s in the dog. In earlier studies, histamine levels were measured by bioassay, but subsequently fluorometric and radio-enzymatic techniques were employed [8]. 


\section{HISTAMINE RECEPTORS}

Histamine is an important biogenic amine and has multiple effects that are mediated through specific surface receptors on specific target cells. Four types of histamine receptors have now been identified. In 1966, histamine receptors were first differentiated into $\mathrm{H} 1$ and $\mathrm{H} 2$ [61], and it was reported that some responses to histamine were inhibited by low doses of mepyramine (pyrilamine), whereas others were unsympathetic. In 1999, a third histamine receptor subtype was cloned and termed as H3 [22]. Subsequently in 2000, the fourth histamine receptor subtype was reported which was termed as H4 [21] and introduced a significant chapter in the story of histamine effects.

\section{A. Histamine H1-Receptor}

\section{Cellular Distribution and Functional Characterization}

In different mammalian tissues, the study of the distribution of histamine H1-receptors (H1Rs) has been significantly helped by the development of specific radioligands for this subtype. In 1997, [3H]mepyramine a selective radioligand was developed (Table 1) [62], and since then it has been used to identify H1-receptors in a wide variety of tissues such as gastrointestinal tract, central nervous system, airways and vascular smooth muscle cells, mammalian brain, hepatocytes, nerve cells, endothelial cells, chondrocytes, monocytes, neutrophils, dendritic cells, $\mathrm{T}$ and $\mathrm{B}$ lymphocytes (Table 2), the cardiovascular system and genitourinary system, endothelial cells and adrenal medulla in which H1receptor mediates different biological properties of allergic responses such as typical immediate responses of allergic reaction type I like redness, itching and swelling ("triple re- sponse"). In many pathological processes of allergy, including allergenic rhinitis, atopic dermatitis, conjunctivitis, urticaria, asthma, and anaphylaxis, H1-receptors are involved. The receptors also mediate bronchoconstriction and enhanced vascular permeability in the lung [17, 63-65]. It has been noticed that $[3 \mathrm{H}]$ mepyramine binds to secondary nonH1-receptor sites in various tissues and cells [66-70]. In addition to $[3 \mathrm{H}]$ mepyramine, which predominantly binds to a protein homologous with debrisoquine 4-hydroxylase cytochrome P450 in rat liver [71], this nonspecific binding can be blocked by quinine. This investigation led to the demonstration that quinine may be used to block binding to other lower affinity sites [72], and it was thus proved that all secondary binding sites for $[3 \mathrm{H}]$ mepyramine were not sensitive to inhibition through quinine [69]. Many researchers have shown that a 38 to $40 \mathrm{kDa}$ protein was isolated from DDT1MF-2 cells, that binds H1R antagonists with specific $\mathrm{K}_{\mathrm{D}}$ values in the $\mu \mathrm{M}$ range, but that was not sensitive to inhibition through quinine and also that DDT1MF-2 cells possess $[3 \mathrm{H}]$ mepyramine binding sites which have the characteristics of histamine $\mathrm{H} 1$-receptors (i.e., $\mathrm{K}_{\mathrm{D}}$ values in the $\mathrm{nM}$ range) to mediate functional responses, and those were produced by H1R activation [69, 73, 74]. Other radioligands that have been demonstrated to study histamine H1-receptors are $[3 \mathrm{H}]$ mianserin, [3H]doxepin, [125I]iodobolpyramine, [125I] iodoazidophenpyramine, and [3H](1)-N-methyl-4methyldiphenhydramine [75-80]. [125I]Iodobolpyramine has been successfully used for autoradiographic localization of H1Rs in the brain of guinea pig, whereas, it was used with lower success for localization in rat brain (Table 1) [78, 81]. Slow dissociation of $[3 \mathrm{H}]$ mepyramine from $\mathrm{H} 1 \mathrm{Rs}$ has been shown at low temperature (i.e., $4^{\circ} \mathrm{C}$ ) and this denotes that $[3 \mathrm{H}]$ mepyramine can also be used for autoradiography (Ta-

Table 1. Characterization of Histamine Receptors Agonist, Antagonist and Radioligand

\begin{tabular}{|c|c|c|c|}
\hline $\begin{array}{l}\text { Receptor } \\
\text { Subtypes }\end{array}$ & Agonists with Potency & Antagonists with Potency & $\begin{array}{l}\text { Radioligands with Equilibrium Constant } \\
\text { for Dissociation (Kd) }\end{array}$ \\
\hline H1 & $\begin{array}{l}\text { Histamine }(100)^{\mathrm{a}, \mathrm{b}}, \text { Dimethylhistaprodifen } \\
(240)^{\mathrm{a}}, \text { Methylhistaprodifen }(340)^{\mathrm{a}}, \text { Histamine- } \\
\text { trifluoromethyltoluidine }(\text { HTMT })^{\mathrm{c}} \text {, } \\
\text { 2-(3-trifluoromethylphenyl) histamine }(128)^{\mathrm{a}, \mathrm{b}} \text {, } \\
\text { 2-Thiazolylethylamine }(26)^{\mathrm{a}} \text {, } \\
\text { 2-Pyridylethylamine }(6)^{\mathrm{a}}\end{array}$ & $\begin{array}{l}\text { Mepyramine }\left(\mathrm{pA}_{2} 9.4\right)^{\mathrm{a}}, \\
(+) \text {-Chlorpheniramine }\left(\mathrm{pA}_{2} 9.4\right)^{\mathrm{a}},(-)- \\
\text { Chlor-pheniramine }\left(\mathrm{pA}_{2} 6.7\right)^{\mathrm{a}}, \text { Trans- } \\
\text { triprolidine }\left(\mathrm{pA}_{2} 10.0\right)^{\mathrm{a}}, \text { Temelastine } \\
\left(\mathrm{pA}_{2} 9.5\right)^{\mathrm{a}}, \text { Promethazine }\left(\mathrm{pA}_{2} 8.9\right)^{\mathrm{a}}, \\
\text { Diphenhydramine }\left(\mathrm{pA}_{2} 9.0\right)^{\mathrm{a}}, \text { Tripelen- } \\
\text { namine }\left(\mathrm{pA}_{2} 8.5\right)^{\mathrm{a}}, \text { Chlorpromazine }\left(\mathrm{pA}_{2}\right. \\
8.9)^{\mathrm{a}}\end{array}$ & $\begin{array}{l}{\left[{ }^{3} \mathrm{H}\right] \text {-Mepyramine (Kd } 0.8 \mathrm{nM} \text { : guinea-pig }} \\
\text { brain, ileum) })^{\mathrm{a}, \mathrm{b}} \text {, } \\
{\left[{ }^{125} \mathrm{I}\right]-\text { Iodobolpyramine }(\mathrm{Kd} 0.01 \mathrm{nM} \text {, guinea- }} \\
\left.\text { pig brain })^{\mathrm{a}},{ }^{125} \mathrm{I}\right] \text {-Iodoazidophen-pyramine } \\
(\mathrm{Kd} 0.01 \mathrm{nM} \text {, guinea-pig cerebellum) })^{\mathrm{a}, \mathrm{b}}\end{array}$ \\
\hline $\mathrm{H} 2$ & $\begin{array}{l}\text { Histamine }(100)^{\mathrm{a}, \mathrm{b}}, \\
\text { Arpromidine }(10230)^{\mathrm{a}, \mathrm{b}}, \text { Impromidine }(4810)^{\mathrm{a}}, \\
\mathrm{b}, \text { Sopromidine }(740)^{\mathrm{a}, \mathrm{b}}, \text { Amthamine }(150)^{\mathrm{a}, \mathrm{b}} \text {, } \\
\text { Dimaprit }(71)^{\mathrm{a}, \mathrm{b}} \\
\text { 4-Methylhistamine }(43)^{\mathrm{a}, \mathrm{b}}\end{array}$ & $\begin{array}{l}\text { Cimetidine }\left(\mathrm{pA}_{2} 6.1\right)^{\mathrm{a}}, \text { Ranitidine }\left(\mathrm{pA}_{2}\right. \\
6.7)^{\mathrm{a}}, \text { Famotidine }\left(\mathrm{pA}_{2} 7.8\right)^{\mathrm{a}}, \text { Zolanti- } \\
\text { dine }\left(\mathrm{pA}_{2} 7.6\right)^{\mathrm{a}}, \text { Mifentidine }\left(\mathrm{pA}_{2} 7.6\right)^{\mathrm{a}}, \\
\text { Titotidine }\left(\mathrm{pA}_{2} 7.8\right)^{\mathrm{a}} \text {, Iodoaminopotenti- } \\
\text { dine }\left(\mathrm{pA}_{2} 8.6\right)^{\mathrm{a}}\end{array}$ & $\begin{array}{l}{\left[{ }^{3} \mathrm{H}\right] \text {-Tiotidine }(25 \mathrm{nM})^{\mathrm{a}, \mathrm{b}},\left[{ }^{125} \mathrm{I}\right] \text {-Iodoamino- }} \\
\text { potentidine }(\mathrm{Kd} 0.3 \mathrm{nM})^{\mathrm{a}, \mathrm{b}}, \\
{\left[{ }^{125} \mathrm{I}\right] \text {-Iodoazido-potentidine }(\mathrm{Kd} 10 \mathrm{nM}) \text { a, b }} \\
\text { (all guinea-pig brain membrains) }\end{array}$ \\
\hline $\mathrm{H} 3$ & $\begin{array}{l}\text { Histamine }(100)^{\mathrm{a}, \mathrm{b}}, \\
\text { Imetit }(6200)^{\mathrm{a}, \mathrm{b}}, \\
\text { Immepip }(2457)^{\mathrm{a}, \mathrm{b}}, \\
\text { R- } \alpha \text {-methylhistamine }(1550)^{\mathrm{a}, \mathrm{b}}\end{array}$ & 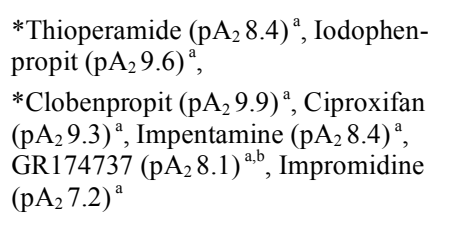 & $\begin{array}{l}{\left[{ }^{3} \mathrm{H}\right]-\mathrm{R}-\alpha \text {-methylhistamine }(\mathrm{Kd} 0.5 \mathrm{nM})^{\mathrm{a}, \mathrm{b}},} \\
{\left[{ }^{3} \mathrm{H}\right]-\mathrm{N}^{\alpha}-\text { methylhistamine }(\mathrm{Kd} 2.0 \mathrm{nM}){ }^{\mathrm{a}, \mathrm{b}},} \\
\left.\left.{ }^{125} \mathrm{I}\right]- \text { Iodophenpropit }(\mathrm{Kd} 0.3 \mathrm{~nm})^{\mathrm{a}, \mathrm{b}},{ }^{125} \mathrm{I}\right]- \\
\text { Iodoproxyfan }(\mathrm{Kd} 0.065 \mathrm{nM})^{\mathrm{a}, \mathrm{b}}, \\
{[3 \mathrm{H}]-\mathrm{GR} 168320(\mathrm{Kd} 0.1 \mathrm{nM})^{\mathrm{a}, \mathrm{b}} \text { (all rat cere- }} \\
\text { bral cortical membranes in Tris buffer) }\end{array}$ \\
\hline $\mathrm{H} 4$ & $\begin{array}{l}\text { Imetit }\left(\mathrm{pA}_{2} 8.6\right)^{\mathrm{c}}, \\
\text { Immepip }\left(\mathrm{pA}_{2} 8\right)^{\mathrm{c}}, \\
{ }^{*} \text { Clobenpropit }\left(\mathrm{pA}_{2} 7.9, \text { partial agonist }\right)^{\mathrm{c}} \text {, } \\
\text { 4-Methylhistamine }\left(\mathrm{pA}_{2} 7.3\right)^{\mathrm{c}}\end{array}$ & $\begin{array}{l}\text { JNJ } 10191584(7.6)^{\mathrm{c}},{ }^{*} \text { Thioperamide } \\
(7.6)^{\mathrm{c}}\end{array}$ & None to date \\
\hline
\end{tabular}


Table 2. Characteristics of the Histamine Receptor Subtypes

\begin{tabular}{|c|c|c|c|c|}
\hline Characteristics & $\mathbf{H}_{1}$-Receptor & $\mathrm{H}_{2}$-Receptor & $\mathrm{H}_{3}$-Receptor & $\mathrm{H}_{4}$-Receptor \\
\hline $\begin{array}{l}{ }^{\mathrm{a}, \mathrm{b}} \text { Receptor described, } \\
\text { human gene cloned (years) }\end{array}$ & 1966,1993 & 1972,1991 & 1983,1999 & 1994,2000 \\
\hline $\begin{array}{l}{ }^{\mathrm{a}} \text { Receptor proteins in hu- } \\
\text { man }\end{array}$ & 487 amino acids, $56 \mathrm{kD}$ & 359 amino acids, $40 \mathrm{kD}$ & $\begin{array}{l}445 \text { amino acids, } 70 \mathrm{kD} \\
\text { splice variants }\end{array}$ & 390 amino acids \\
\hline $\begin{array}{c}{ }^{\mathrm{a}, \mathrm{c}} \text { Chromosomal location in } \\
\text { human }\end{array}$ & $3 \mathrm{p} 25,3 \mathrm{p} 14-21$ & $5,5 \mathrm{q} 35.3$ & $20,20 \mathrm{q} 13.33$ & $18 \mathrm{q} 11.2$ \\
\hline $\begin{array}{l}{ }^{b} \text { Equilibrium constant for } \\
\text { dissociation }(\mathrm{Kd})\end{array}$ & $\sim 10 \mu \mathrm{mol} / \mathrm{L}$ & $\sim 30 \mu \mathrm{mol} / \mathrm{L}$ & $\sim 10 \mathrm{nmol} / \mathrm{L}$ & $20-40 \mathrm{nmol} / \mathrm{L}$ \\
\hline${ }^{\mathrm{a}}$ Receptor expression & $\begin{array}{l}\text { Widespread, including neu- } \\
\text { rons, smooth muscle (e.g., } \\
\text { airways, vascular), and other } \\
\text { types of cells.* }\end{array}$ & $\begin{array}{l}\text { Widespread, including } \\
\text { gastric mucosa parietal } \\
\text { cells, smooth-muscle, heart, } \\
\text { and other types of cells.* }\end{array}$ & $\begin{array}{l}\text { High expression in hista- } \\
\text { minergic neurons, low ex- } \\
\text { pression elsewhere. }\end{array}$ & $\begin{array}{l}\text { High expression in bone } \\
\text { marrow and peripheral } \\
\text { hematopoietic cells, low } \\
\text { expression elsewhere. }\end{array}$ \\
\hline${ }^{\mathrm{c}}$ Gene Structure & Intronless & Intronless & Three introns & Two introns \\
\hline${ }^{\mathrm{a}} \mathrm{G}-$ protein coupling & $\mathrm{G} \alpha \mathrm{q} / 11$ & $\mathrm{G} \alpha \mathrm{s}$ & $\mathrm{Gi} / \mathrm{o}$ & Gi/o \\
\hline $\begin{array}{l}{ }^{\mathrm{a}, \mathrm{b}} \text { Activated intracellular } \\
\text { signals (principal signaling } \\
\text { effector molecules) }\end{array}$ & $\begin{array}{l}\mathrm{Ca}^{2+\uparrow}, \mathrm{cGMP}, \mathrm{NF}-\kappa \mathrm{B}, \\
\mathrm{PLC} \uparrow \text {, phospholipase A2, } \\
\text { and D, cAMP, NOS }\end{array}$ & $\begin{array}{l}\text { cAMP } \uparrow, \mathrm{Ca}^{2+} \text {, protein kinese } \\
\mathrm{C}, \mathrm{c} \text {-fos, phos- pholipase C }\end{array}$ & $\begin{array}{l}\mathrm{Ca}^{2+} \uparrow, \text { MAP kinase } \uparrow \\
\text { inhibition of cAMP } \downarrow\end{array}$ & $\begin{array}{c}\mathrm{Ca}^{2+} \uparrow, \text { MAP kinase } \uparrow \\
\text { Inhibition of cAMP } \downarrow\end{array}$ \\
\hline
\end{tabular}

Abbreviations: $\mathrm{cAMP}=$ cyclic adenosine monophosphate, $\mathrm{cGMP}=$ cyclic guanosine monophosphate, $\mathrm{MAP}=$ mitogen-activated protein, $\mathrm{NF}-\kappa \mathrm{B}=$ nuclear factor- $\kappa \mathrm{B}, \mathrm{NOS}=$ nitric oxide synthase, $\mathrm{PLC}=$ phospholipase $\mathrm{C}$.

*Other types of cells: epithelial, endothelial cells, neutrophils, eosinophils, monocytes, dendritic cells, T-cells, B cells, hepatocytes, and chondrocytes. ${ }^{\mathrm{a}}[399],{ }^{\mathrm{b}}[1],{ }^{\mathrm{c}}[14]$.

ble 1) [82, 83]. [125I]Iodoazidophenpyramine (Table 1) is a very potent H1-receptor antagonist that can bind irreversibly to H1-receptors following irradiation with ultraviolet light [79]. The existence of H1Rs in the living human brain has been proved by specific ligands [11C]Mepyramine and [11C]doxepin [84, 85]. H1Rs have widely been studied in blood vessels [86-88], and also in smooth muscles [61, 88, 89]. In smooth muscles, such as the guinea pig ileum, which freely generate muscle action potentials, modulation of action-potential discharge by low concentrations of histamine is an important mechanism by which tension is increased [90] and there is evidence that the contractile response to histamine is produced by inositol 1, 4, 5-triphosphateinduced mobilization of intracellular calcium $\left(\mathrm{Ca}^{2+}\right)[91,92]$. Its further effects have been seen in non excitable smooth muscles including airways and vascular smooth muscles, and the contractile H1R stimulation initially involve mobilization of calcium $\left(\mathrm{Ca}^{2+}\right)$ from intracellular stores such as inositol phospholipids hydrolysis [93-96]. H1-receptor stimulation causes various cellular responses in vascular endothelial cells such as: it is responsible for changes in vascular permeability as a result of endothelial cell contraction $[97,98]$; in synthesis of prostacyclin [99, 100]; in platelet-activating factor synthesis [99]; in release of Von Willebrand factor [101], and in nitric oxide release [102].

The study of H1R on human T lymphocytes has been characterized by use of [125I]iodobolpyramine [103] (see also Table 1) and is shown to increase $\left(\mathrm{Ca}^{2+}\right) \mathrm{i}$ [104]. It is being documented that H1R-deficient mice display both strong systemic $\mathrm{T}$ cell and efficient $\mathrm{B}$ cell responses to antigen [105]. The relationship of H1Rs to adrenal medulla which elicit the release of catecholamines has been established many years ago [106-108]. Thus, histamine can stimulate the release of both adrenaline and noradrenaline [108], and also induce phosphorylation of the catecholamine biosynthesis enzyme tyrosine hydroxylase by a mechanism which mediates release of intracellular calcium from cultured bovine adrenal chromaffin cells [109].

The effects of histamine are also seen to elicit the release of leucine- and methionine- enkephalin [110]. Furthermore, many investigators have demonstrated a marked increase in mRNA-encoding proenkephalin A after prolonged exposure to histamine $[110,111]$. Its negative inotropic effects have been observed in human atrial myocardium and also in guinea pig ventricle $[112,113]$.

Genovese et al. [113] suggested that the negative inotropic response of histamine in human myocardium is associated with inhibitory effects on heart rate. This can be unmasked when the positive responses of histamine on the heart rate, and force of contraction (due to histamine $\mathrm{H} 2$ receptors) are mediated through conjoint administration of adenosine or adenosine A1-receptor agonists. However, histamine produces a positive inotropic effect in guinea pig left atria and rabbit papillary muscle by a specific mechanism which is not related with a rise in adenosine $3 \mathrm{c}, 5 \mathrm{c}$-cyclic monophosphate (cAMP) levels [90, 114, 115]. It is being documented that the distribution of H1Rs in mammalian brain with higher densities are found in neocortex, hippocampus, nucleus accumbent, thalamus, and posterior hypothalamus $[90,116]$, however, cerebellum and basal ganglia denotes lower densities [76, 85, 117]. The distribution of H1Rs in rat and guinea pig is very similar to each other [78, 82, 83, 118]. H1-receptor binding sites and mRNA levels were overlapped in most areas of brain except in hippocampus and cerebellum in which the inconsistency is mostly to reflect the presence of exuberance H1Rs in dendrites of pyramidal and Purkinje cells [119]. The activation of H1R inhibits the firing and hyperpolarization in hippocampal neurons [120] and also an apamine sensitive outward current in olfactory bulb interneurons [121], and these effects are mostly generated by intracellular $\mathrm{Ca}^{2+}$ release. However, 
H1R excite various notable factors such as vegetative ganglia [122], hypothalamic supraoptic [23], brainstem [123], thalamic [124], and human cortical neurons [125] through a block of potassium conductance.

The functional characterization of H1R has benefited from the use of many potent and specific antagonists (see Tables 1 and 3) [63, 126]. H1-receptor antagonists are the oldest therapeutic tools of the modern medicine due to their sedative side effects, and the anti-allergic drugs which were developed initially, have now been abandoned. Indeed, H1receptor involves the disturbance of circadian rhythms and locomotor activities as well as the impairment of the exploratory behavior by histamine in the brain, and this is why so-called "non-sedating" $\mathrm{H} 1$ antagonists which cannot cross the blood-brain barrier have been designed. H1-receptor agonists are not readily available because they enhance rather than prevent the onset of allergic pathologies. Histaprodifens are very potent H1R agonists and are more effective than histamine in activating H1R [127]. Some antiinflammatory effects of H1R antagonists at high doses could be non-specific because of histamine and other inflammatory mediators like leukotriene and platelet activating factors released from basophils in response to certain H1Rs antagonists $[1,14]$. Bordetella pertusis-induced histamine sensitization (Bphs) controls Bordetella pertussis toxin (PTX)induced vasoactive amine sensitization elicited by histamine (VAASH) and has an established role in autoimmunity. The congenic mapping links Bphs to the histamine $\mathrm{H}_{1}$ receptor gene $\left(\mathrm{Hrh}_{1} / \mathrm{H}_{1} \mathrm{R}\right)$ and that $\mathrm{H}_{1} \mathrm{R}$ differs at three amino acid residues in VAASH-susceptible and -resistant mice. Hrh1-/mice are protected from VAASH, which can be restored by genetic complementation with a susceptible Bphs/Hrh1 allele, and experimental allergic encephalomyelitis and autoimmune orchitis due to immune deviation. Thus, natural alleles of Hrhl control both the autoimmune T cells and vascular responses regulated by histamine after PTX sensitization. The exact mechanism through which this effect occurs remains unclear and its clinical relevance is still uncertain [128]. The chemical structure of specific H1R-antagonists and agonists are shown in Figs. $(\mathbf{2}, \mathbf{3})$.

\section{Structural Biology of Receptor}

$\mathrm{H}_{1}$ receptors have been cloned from cows, rats, guinea pigs and also from humans. The $\mathrm{H} 1$ receptor contains 486 , 488 or 487 amino acids in rat, mouse and humans, respectively. It contains the typical properties of $\mathrm{G}$ protein coupled receptor (GPCR), namely, seven transmembrane domains of 20-25 amino acids predicted to form an $\alpha$-helice which spans the plasma membrane and an extra cellular $\mathrm{NH}_{2}$ terminal domain with glycosylation site. H1R is encoded by a single exon gene that is located on the distal short arm of chromosome 3p25 in humans see in Fig. (2) and chromosome 6 in mice. Histamine binds to aspartate residues in the transmembrane domain 3 of the H1-receptor, and to asparagine + lysine residues within the transmembrane domain 5 [14].

Its structural studies done by photoaffinity binding properties using [125I]iodoazidophenpyramine (Table 1) and subsequent sodium dodecyl sulfate polyacrylamide gel electrophoresis (SDS-PAGE) analysis demonstrated that the H1receptor protein (molecular weight $56 \mathrm{kDa}$ ) is found under reducing conditions in the brain of rat, guinea pig, and mouse $[79,118,129]$. Similar studies have also been done by using photoaffinity ligand $[3 \mathrm{H}]$ azidobenzamide in bovine adrenal medullar membranes and found labeled peptides in the size range 53 to $58 \mathrm{kDa}$ [130]. In guinea pig heart, the specifically labeled H1R with [125I]iodoazidophenpyramine was found to contain substantially higher molecular weight, while there was no obvious difference in the characteristics of the H1R in tissues (Table 1) [131]. In 1991, H1R was cloned from the bovine adrenal medulla by expression cloning in the Xenopus oocyte system. Interestingly, 491 amino acid protein with a calculated molecular weight of $56 \mathrm{kDa}$ was represented by the deduced amino acid sequence [130]; this protein has the seven transmembrane domains expected of a G-protein coupled receptor (GPCR) and contains Nterminal glycosylation sites. The main feature of the proposed H1R structure is the very large $3^{\text {rd }}$ intracellular loop with 212 amino acids and relatively short intracellular C terminal tail with 17 amino acids. The availability of the bovine sequence and lack of introns has enabled the H1receptor to be cloned from several species including rat [132], guinea pig [129, 133], mouse [134], and human [135, 136]. The human H1-receptor gene has now been localized to chromosome 3 bands 3p14-p21 (Table 2). These clones should be regarded as true species homologues of the H1receptor, while there are notable variations amongst them in some antagonist potencies [23]. Nevertheless, it is clear that the stereoisomers of chlorpheniramine show marked differences between species. For example, the guinea pig H1receptor has a $K_{D}$ of $0.9 \mathrm{nM}$ for (1)-chlorpheniramine, whereas for the rat H1-receptor, the value is nearly $8 \mathrm{nM}$ [23]. Similar variations for chlorpheniramine and other compounds (mepyramine and triprolidine) have been shown in guinea pig and rat brain, respectively [23, 67, 89]. On this basis the species differences may explain why compound [125I]iodobolpyramine can label guinea pig CNS H1receptors, but it is unable to identify H1Rs in the brain of rat $[78,81]$. In brain membranes of both guinea pig and rat the native H1-receptor protein has been solubilized [137, 138], and the solubilized receptor retains similar differences in H1antagonist potency for (1)-chlorpheniramine as that detected in membranes [137]. It is important to note that mepyramine seems to be potent antagonist of the recombinant rat $\mathrm{H} 1$ receptor (i.e. expressed in C6 cells) than of the native histamine H1-receptor in the brain membrane of rat $[23,67,132]$.

In addition, the recombinant studies performed in rat $\mathrm{C} 6$ cells [132] are complicated by the presence of a low level of endogenous histamine H1-receptors (H1Rs) [139], but in the functional studies in untransfected $\mathrm{C} 6$ cells, a high affinity for mepyramine $\left(K_{D} 51 \mathrm{nM}\right)$ has been deduced $[23,139]$. The amino acid sequence alignment of the cloned histamine H1- and H2-receptors led to the suggestion that the third and fifth transmembrane domains (TM3 and TM5 respectively) of receptor proteins are responsible for histamine binding $[140,141]$. In third transmembrane (TM3) of the human H1receptor, Aspartate (107) that is conserved in entire aminergic receptors, has appeared to be essential for the histamine binding, and also H1-receptor antagonists to the H1-receptor [142]. In H1-receptor, the amino acid residues corresponding to Asparagine (198) and Threonine (194) are in corresponding positions in $5^{\text {th }}$ transmembrane domain (TM5) of the human H1-receptor, while the substitution of an Alanine for 


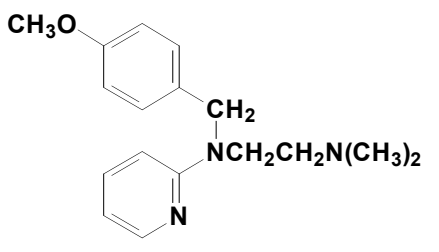

Mepyramine

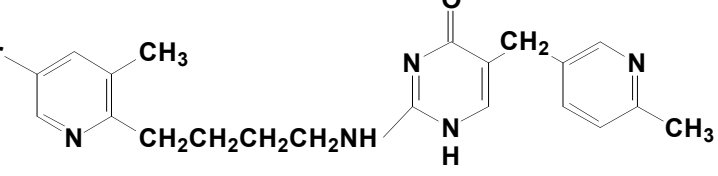

Temelastine

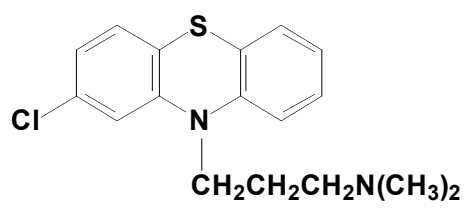

Clorpromazine

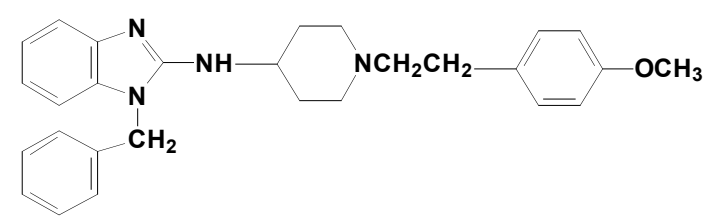

Astemizole

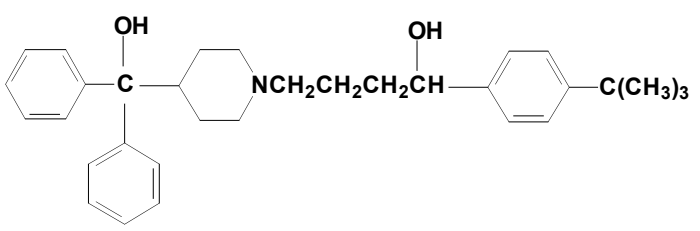

Terfenadine

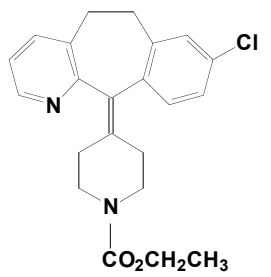

Loratadine

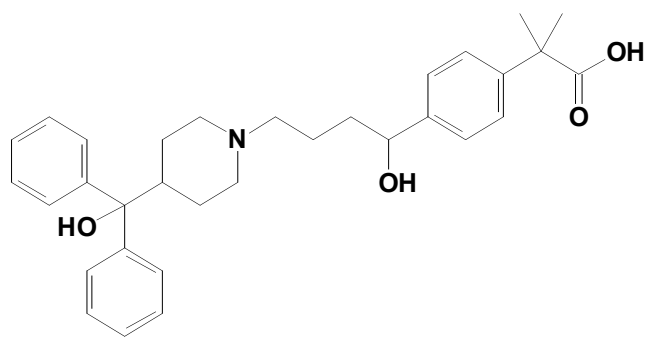

Fexofenadine

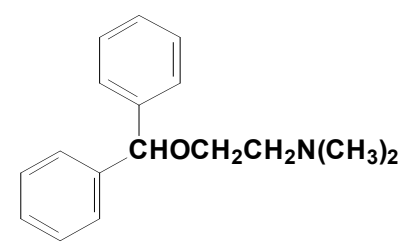

Diphenhydramine<smiles>CC(C)CN1c2ccccc2Sc2ccccc21</smiles>

Promethazine

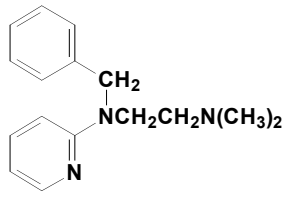

Tripelennamine

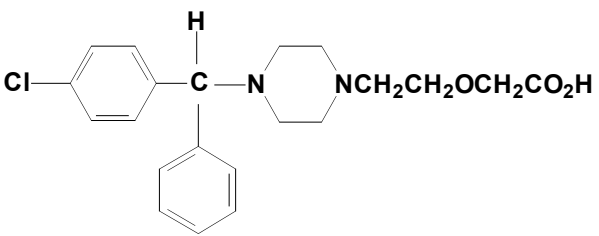

Cetirizine

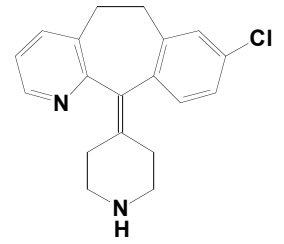

Desloratadine

$\mathrm{CH}_{3}$

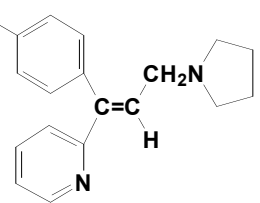

Triprolidine

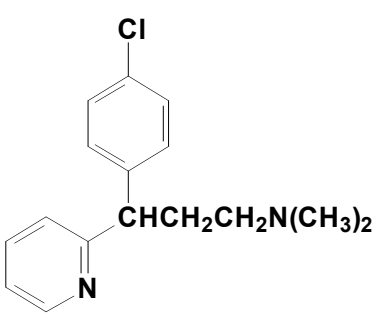

Chlorpheniramine

Fig. (2). Chemical structures of some histamine H1-receptor-antagonists.

Threonine (194) did not influence the binding properties of either agonist or antagonist $[142,143]$. However, the substi- tution of Alanine (198) for Asparagine (198) decreased agonist affinity, while the affinity of antagonist remained un- 


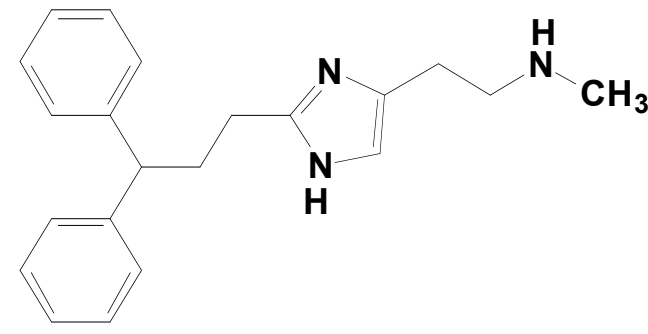

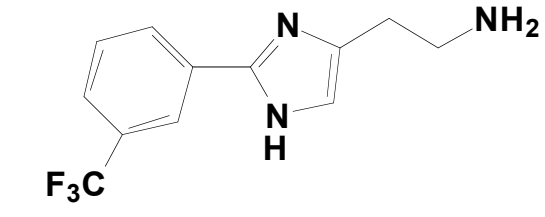

2-[3-(Trifluoromethyl)phenyl]histamine

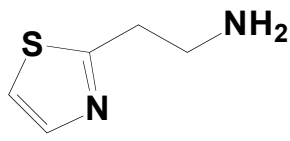

2-(Thiazol-2yl)ethanamine

Methylhistaprodifen

Fig. (3). Chemical structures of some histamine H1-receptor-agonists.

changed $[142,143]$. Similar results have been seen in the mutations to the corresponding residues Threonine (203) and Asparagine (207) in the guinea pig-H1R sequence [144]. In addition to these mutations 2-methylhistamine is affected by the Asparagine (207) Alanine mutation, and H1-selective agonists 2-thiazolylethylamine, 2-pyridylethylamine, and 2(3-bromophenyl) histamine are much less influenced through this mutation [144, 145]. This suggested that Asparagine (207) interacts with the Nt-nitrogen of histamine imidazole ring.

However, it has been shown that Lysine (200) interacts with the Np-nitrogen of histamine ring, and that it is important for the activation of the H1R by histamine and the nonimidazole agonist, 2-pyridylethylamine [63]. Furthermore, Leurs et al. [70] has demonstrated that the Lysine (200) Alanine mutation did not alter the binding affinity of 2-pyridylethylamine to H1R of guinea pig. Thus, the studies on the organization, genomic structure and promoter function of the human $\mathrm{H} 1 \mathrm{R}$ revealed a $5.8 \mathrm{~kb}$ intron in the 50 flanking region of this gene, different binding sites for various transcription factors, and the absence of TATA and CAAT sequences at the appropriate locations [146].

\section{Signaling Mechanisms}

H1-receptor is a $\mathrm{G} \alpha \mathrm{q} / 11$-coupled protein with a very large third intracellular loop and a relatively short C-terminal tail see in Fig. (4). The main signal induced by ligand binding is the activation of phospholipase C-generating inositol 1, 4, 5-triphosphate and 1,2-diacylglycerol (DAC) leading to increased cytosolic $\mathrm{Ca}^{2+}$. The enhanced intracellular $\mathrm{Ca}^{2+}$ levels appear to account for the different pharmacological properties promoted through the receptor including nitric oxide (NO) production, liberation of arachidonic acid from phospholipids, contraction of smooth muscles, dilatation of arterioles and capillaries, vascular permeability in vessels as well as stimulation of afferent neurons, and increased cAMP, and also cGMP levels [64, 147] (see also Table 2). This receptor also stimulates nuclear factor kappa B (NFkB) by $\mathrm{G} \alpha \mathrm{q} / 11$ and $\mathrm{G} \beta \gamma$ upon binding of agonist, while stimulation of NFKB occurs only via G $\beta \gamma$ leading to (pro)inflammatory mediators $[70,89,148]$. The number of tissues and cell types in which a H1R-mediated signals increases in either inositol phosphate accumulation or intracellular calcium mobilization has been described extensively and further details are provided in several comprehensive reviews [89, 149, 150]. In Chinese hamster ovary $(\mathrm{CHO})$ cells $\mathrm{Ca}^{2+}$ mobilization and $[3 \mathrm{H}]$ inositol phosphate accumulation has been observed due to stimulation by histamine when $\mathrm{CHO}$ cells are transfected with H1R-complementary deoxyribonucleic acid (cDNA) of the human, bovine, and guinea pig $[150,151]$. It is worth demonstrating that in some tissues histamine can stimulate inositol phospholipid hydrolysis independently of H1Rs. Thus, in the longitudinal smooth muscle of guinea pig ileum and neonatal rat brain $[92,152]$, a component can be identified in response to histamine that is resistant to inhibition by H1R-antagonists. It is yet to be established whether these effects are due to "tyramine-like" effects of histamine on neurotransmitter release or direct effects of histamine on the associated G-proteins $[153,154]$. In addition to well known effects on the inositol phospholipid signal transduction systems, several other signal transduction pathways can lead to stimulation of H1R and it seems to be secondary to changes in intracellular $\mathrm{Ca}^{2+}$ concentration or protein kinase $\mathrm{C}(\mathrm{PKC})$ activation. Thus, nitric oxide synthase activity (via a $\mathrm{Ca}^{2+} /$ calmodulin-dependent pathway), and subsequent stimulation of soluble guanylyl cyclase in a wide variety of various cell types can be activated by histamine [155-158]. The H1R can stimulate the arachidonic acid release and arachidonic acid metabolites synthesis such as prostacyclin and thromboxane $[150,159]$. It is being interestingly demonstrated that the histamine-stimulated release of arachidonic acid is partially inhibited $(\sim 40 \%)$ by pertussis toxin, when CHO-K1 cells transfected with the guinea pig H1R and the same response is also shown in HeLa cell possessing a native H1R to resist pertussis toxin treatment [150]. The substantial changes in the intracellular levels of cAMP can be produced by H1-receptor activation, but in most tissues, H1R activation does not stimulate adenylyl cyclase directly, and acts for the amplification of cAMP effects to histamine H2-, adenosine A2-, and also vasoactive intestinal polypeptide receptors [160-162]. The role of both intracellular $\mathrm{Ca}^{2+}$ ions and protein kinase $\mathrm{C}$ has been demonstrated in various cases in this augmentation response [161]. H1R stimulation can also lead to both cAMP responses and to an increasement of forskolinactivated cAMP formation when $\mathrm{CHO}$ cells are transfected with the bovine or guinea pig H1R $[150,163]$.

\section{B. Histamine H2-Receptor}

\section{Cellular Distribution and Functional Characterization}

The H2R is located on chromosome 5 in humans. Similar to what has been demonstrated for H1R, the histamine binds to transmembrane (TM) domains 3 (aspartate) and TM 5 (threonine and aspartate). The short $3^{\text {rd }}$ intra-cellular loop and the long C-terminal tail make a suitable feature of $\mathrm{H} 2 \mathrm{R}$ subtype, and the rat N-terminal extracellular tail has $\mathrm{N}$ linked glycosylation sites [164]. Similar to H1R, H2R is expressed in different cell types (Table 2). It has been documented that $\mathrm{H} 2 \mathrm{R}$ is mostly involved in suppressive activities 


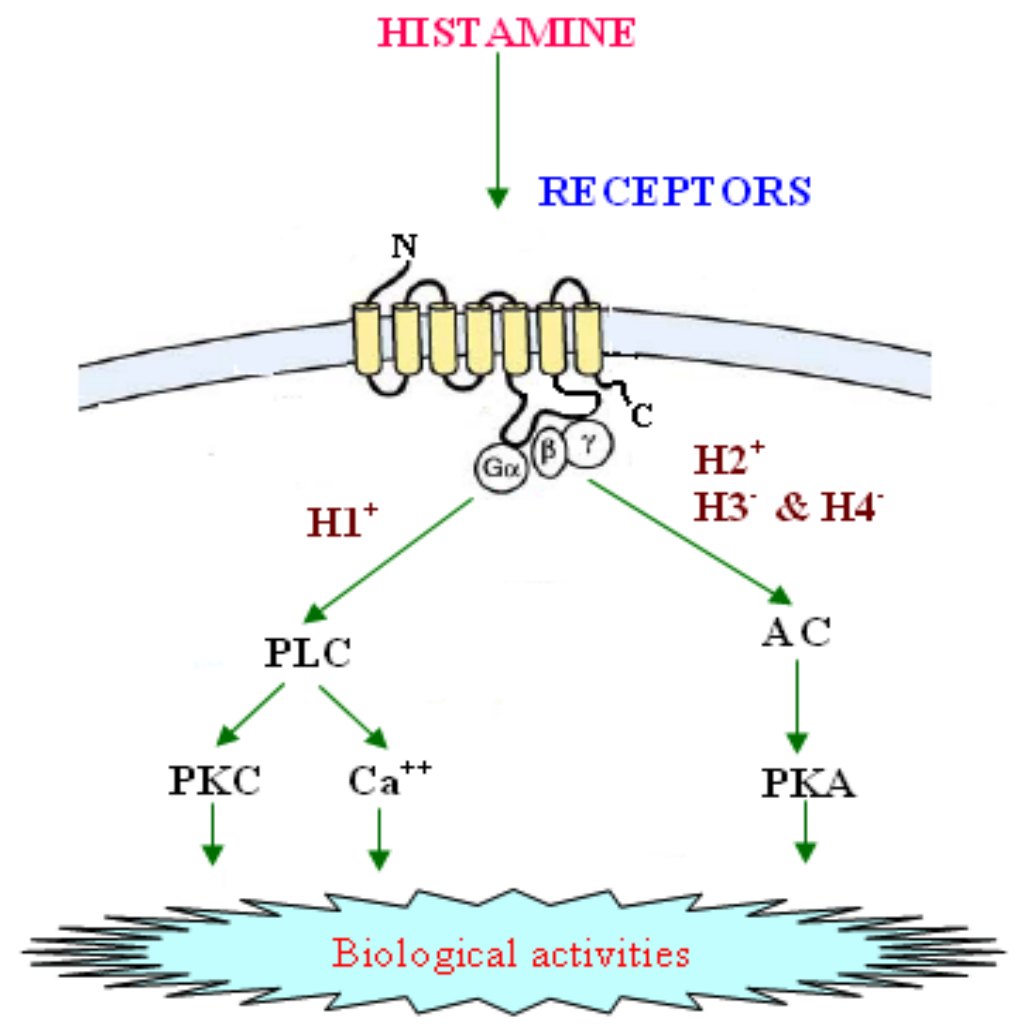

Fig. (4). The classical binding sites of histamine and their main signaling pathways such as AC ( adenylate cyclase), PKC (protein kinase C), PKA (protein kinase A), PLC (phospholipase C), $\mathrm{H}^{+}{ }^{+}$or $\mathrm{H}_{2}^{+}$(stimulation via $\mathrm{H} 1$ or $\mathrm{H} 2$ receptor), $\mathrm{H}^{-}$\& $\mathrm{H}^{-}$(inhibition via $\mathrm{H} 3$ and $\mathrm{H} 4 \mathrm{re}^{-}$ ceptors).

of histamine, while positive effects are mediated through H1R. It was quite clear that the activation of H2R regulates various functions of histamine including heart contraction, gastric acid secretion, cell proliferation, differentiation and immune response. It has been demonstrated that H2R antagonists, such as zolantidine, is active in the treatment of stomach and duodenal ulcers and it strongly suggests that the clinical potency relates to the antagonistic effect of these drugs on the secretion of stomach acids [14].

Hill [89] designed a study to map the distribution of H2Rs by using radiolabeled H2R-antagonists, and achieved more affinity with $[3 \mathrm{H}]$ titotidine (Table 1) for the H2R in guinea pig brain, lung parenchyma, and $\mathrm{CHO}-\mathrm{K} 1$ cells transfected with the human H2-receptor cDNA [165-167], but it was not successful in the studies of rat brain [168]. The most successful H2R-radioligand is [125I]iodoaminopotenti-dine, which has high affinity $\left(\mathrm{K}_{\mathrm{D}} 50.3 \mathrm{nM}\right)$ for the $\mathrm{H} 2 \mathrm{R}$ in brain membranes (Table 1) $[129,169-171]$ and also in CHO-K1 cells expressing the cloned rat H2R [171]. This compound has also been used for autoradiographic mapping of H2Rs in the brain of mammal [131, 170]. [125I]iodoaminopotentidine is also the most successful H2R-radioligand (Table 1), which was used to map the distribution of H2Rs in human brain with highest densities in the basal ganglia, hippocampus, amygdale, and cerebral cortex, and also lowest densities were identified in cerebellum and hypothalamus [170]. In guinea pig brain, a similar distribution has been observed [129]. Irreversible labeling has also been successfully seen by [125I]iodoazidopotentidine (Table 1) [129, 169]. H2R-stimulated cyclic AMP accumulation or adenylyl cyclase activity in Fig. (4) has been shown in various tissues including gastric cells, cardic tissue and brain $[165,172$, 173] and gastric cells [174]. The potent effect of H2Rs have been demonstrated on gastric acid secretion and the inhibition of this secretory process through $\mathrm{H} 2 \mathrm{R}$ antagonists had provided regulatory evidence for physiological role of histamine in gastric acid secretion $[175,176]$. In cardiac tissues of most animal species, high concentrations of histamine were present which can mediate positive chronotropic and inotropic impacts on atrial or ventricular tissues by $\mathrm{H} 2 \mathrm{R}$ stimulation [177, 178]. Also H2R-mediated smooth muscle relaxation has been documented in vascular smooth muscle, uterine muscle and in airways [179-183]. Hill [89] had demonstrated that the effects of H2Rs can inhibit a variety of functions within the immune system. H2Rs have been shown to negatively regulate the release of histamine on basophils and mast cells $[184,185]$. The inhibition of antibody synthesis, T-cell proliferation, cell-mediated cytolysis, and cytokine production were the increasing evidence of H2Rs on lymphocytes [186-189]. The chemical structure of specific H2R-antagonist and -agonists are shown in Figs. $(\mathbf{5}, \mathbf{6})$.

\section{Structural Biology of Receptor}

The structural studies of H2R have been demonstrated using [125I]iodoazidopotentidine and sodium dodecyl sulfate-polyacrylamide gel electrophoresis (SDS-PAGE) and it was suggested that the $\mathrm{H} 2 \mathrm{R}$ in guinea pig hippocampus and striatum has a molecular weight of $59 \mathrm{kDa}$ [129]. However, comparison with the calculated molecular weights (40.2 to $40.5 \mathrm{kDa}$ ) for the cloned H2Rs indicates that the native H2R in the brain of guinea pig was glycosylated. It was highly significant with the proposal that entire cloned H2R proteins 


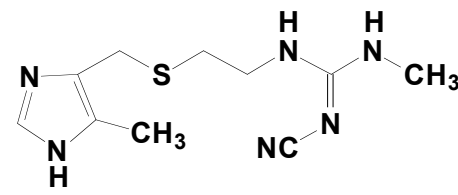

Cimetidine

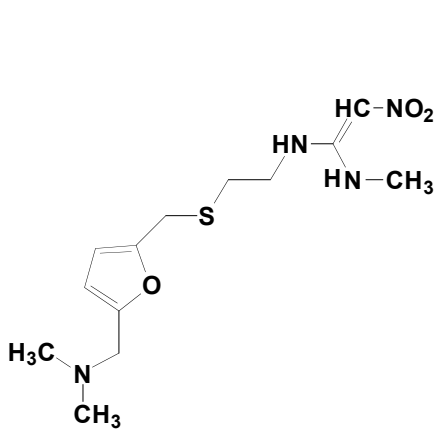

Ranitidine

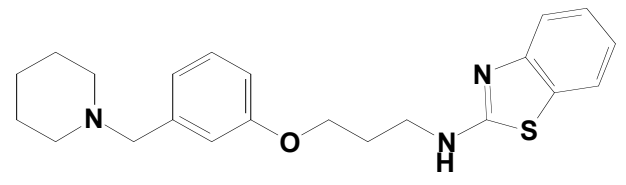

Zolantidine

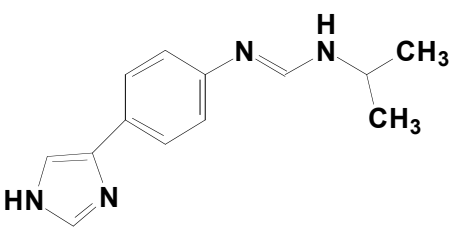

Mifentidine

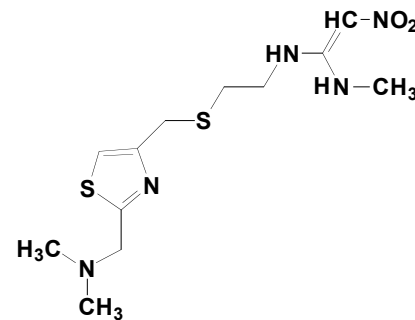

Nizatidine

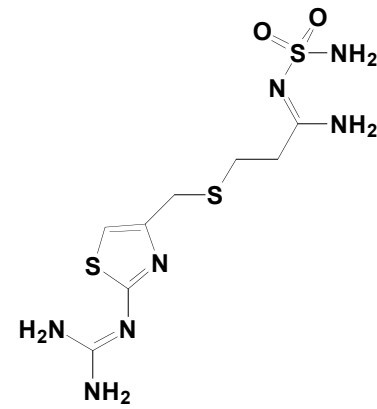

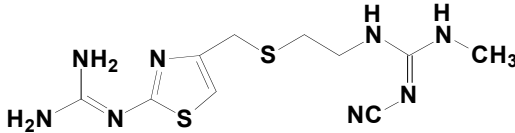

Titotidine
Famotidine

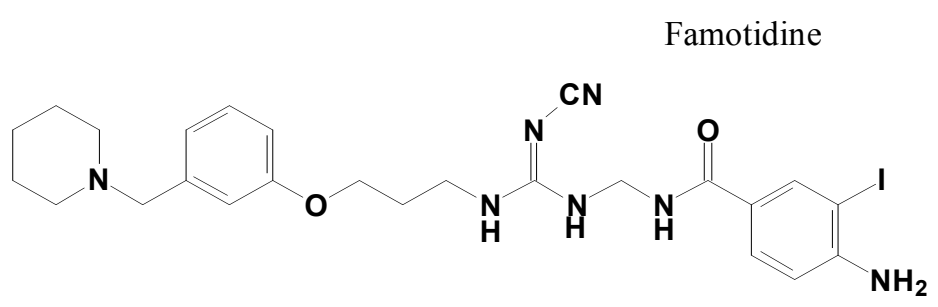

Iodoaminopotentidine

Fig. (5). Chemical structures of some histamine H2-receptor-antagonists.

possess N-glycosylation sites in the N-terminus region [190192]. Fukushima et al. [193] has suggested that removal of these glycosylation sites by site-directed mutagenesis showed that N-glycosylation of the H2R is not essential for cell surface localization, ligand binding, or coupling via Gs to adenylyl cyclase. Gantz and colleagues for the first time successfully cloned H2R using the polymerase chain reaction to amplify a partial length H2R sequence from canine gastric parietal cDNA using degenerate oligonucleotide primers and this sequence was then used to identify a full length H2R clone following screening of a canine genomic library [167]. Following this cloning, many researchers have cloned the rat, human, guinea pig, and mouse H2Rs [167, 191, 192, 194]. These intronless gene (DNA) sequences encode 359 amino acids for canine, human, guinea pig or 358 amino acids for rat receptor protein which has the general properties of a G-protein-coupled receptor (GPCR) (Table 2). The radioligand binding studies using [125I]iodoaminopotentidine were attempted to show the expression of rat and human $\mathrm{H} 2 \mathrm{R}$ proteins in $\mathrm{CHO}$ cells and revealed the expected pharmacological specificity as shown in Table $\mathbf{1}[150,171]$. Chromosomal mapping studies have demonstrated that the H2R gene was localized to human chromosome 5 [192]. Birdsall [140] has compared H2R sequence with other biogenic amine G-protein coupled receptors (GPCRs), and demonstrated that an aspartate in transmembrane (TM) domain 3 and an aspartate and threonine residue in TM 5 were more responsible for histamine binding. Replacement of aspartate (98) with asparagine residue in the canine H2R provides significant results in a receptor that does not bind the titotidine, an antagonist, and hence does not stimulate cyclic adenosine monophosphate (cAMP) accumulation in histamine response [195]. On changing the aspirate (186) residue of TM 5 to an alanine residue there occurs complete loss of the antagonist titotidine binding without affecting the EC 50 for cAMP formation in response to histamine stimulation. Other change was observed on changing the threonine (190) residue to an alanine residue, resulted in a lower $\mathrm{K}_{\mathrm{D}}$ for titotidine antagonist and also a reduction in both the histamine EC 50 value and maximal cAMP response [195]. Mutation of Aspirate (186) and Glycine (187) residue in the canine histamine H2-receptor to Alanine (186) and Serine (187) residue produces a bifunctional receptor, which can be activated through adrenaline, and inhibited via both cimetidine and propranolol [196]. Thus, these results indicate that pharmacological specificity of the $\mathrm{H} 2 \mathrm{R}$ resides in only limited key amino acid residues.

\section{Signaling Mechanisms}

$\mathrm{H} 2 \mathrm{R}$ is coupled both to adenylate cyclase and to phosphoinositide second messenger systems via separate GTPdependent mechanisms. Receptor binding stimulates activation of c-Fos, c-Jun, protein kinase C (PKC) and p70S6kinase $[14,89,145,174]$ see in Fig. (4). Histamine 


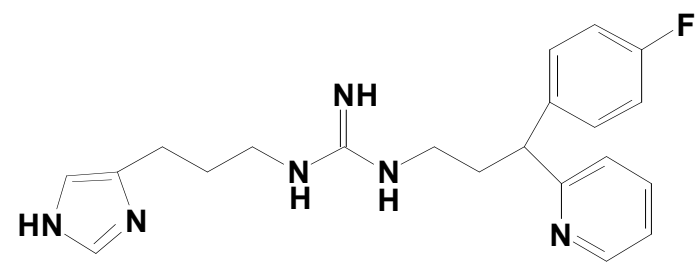

Arpromidine

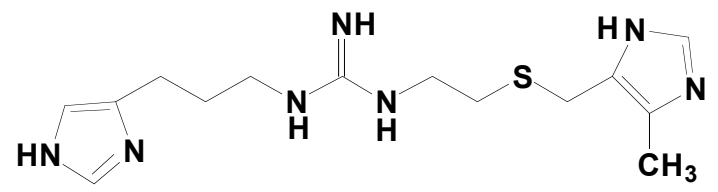

Impromidine

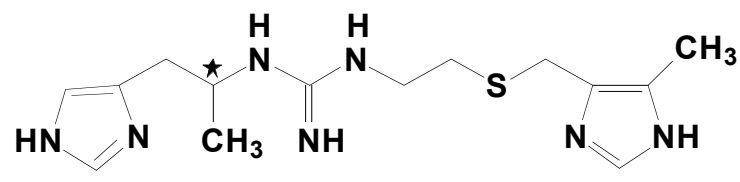

Sopromidine (*: R chirality)

Fig. (6). Chemical structures of some histamine H2-receptor-agonists.

was proved to be a highly potent stimulant of cAMP accumulation in various cells, and H2R-dependent impacts of histamine were predominantly mediated through cAMP [14, 174], particularly those of central nervous system (CNS) origin [23]. Thus, H2R-mediated impacts on cAMP accumulation have been well documented and had been demonstrated in brain slices, gastric mucosa, fat cells, cardiac myocytes, vascular smooth muscle, basophils and neutrophils [23, 172, 197-199]. In addition, H2R-mediated cAMP accumulation had been observed in Chinese hamster ovary (CHO) cells transfected with the rat, canine, or human $\mathrm{H} 2 \mathrm{R}$ cDNA [167, 190, 193, 200]. In both brain and cardiac muscle membranes, the direct stimulation of adenylyl cyclase activity in cell free preparations had been detected [201, 202].

However, Hill [89] had suggested that the caution is required regarding the interpretation of receptor characterization studies using histamine-stimulated adenylyl cyclase activity alone. A most striking feature of studies of H2Rstimulated adenylyl cyclase activity in membrane preparations was the potent antagonism demonstrated with certain neuroleptics and antidepressants [204]. In intact cellular systems, most of the neuroleptics and antidepressants were approximately 2 orders of magnitude weaker as antagonists of histamine-stimulated cAMP accumulation [203, 205]. One highly potential explanation of these variations resides within the buffer systems used for the cell-free adenylyl cyclase assays, and some differences in potency of some antidepressants and neuroleptics have been demonstrated when membrane binding of $\mathrm{H} 2 \mathrm{Rs}$ has been evaluated using [125I]iodoaminopotentidine (Table 1). However, the variations observed in the $\mathrm{Ki}$ values deduced from studies of ligand binding in different buffers are not as large as the variations in $\mathrm{K}_{\mathrm{B}}$ values obtained from functional studies. For example, in the case of amitriptyline, no difference was observed in binding affinity in Krebs and Tris buffers [206]. In

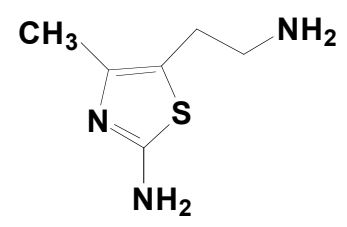

Amthamine

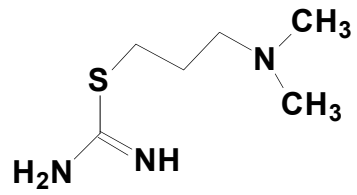

Dimaprit

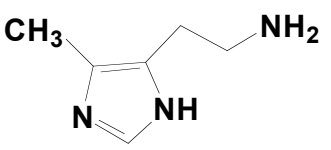

4-Methylhistamine addition to Gs-coupling to adenylyl cyclase, H2Rs are coupled to other signaling systems also. For example, H2R stimulation has been demonstrated to enhance the intracellular free concentration of calcium $\left(\mathrm{Ca}^{2+}\right)$ ions in gastric parietal cells $[207,208]$. In some cell systems, $\mathrm{G} \alpha_{\mathrm{q}}$ coupling to PLC and intracellular $\mathrm{Ca}^{2+}$ had been demonstrated (Table 2). In HL-60 cells, a similar calcium $\left(\mathrm{Ca}^{2+}\right)$ response to $\mathrm{H} 2 \mathrm{R}$ stimulation had been demonstrated [209], and similar case was observed in hepatoma-derived cells transfected with the canine H2Rs cDNA [210]. Therefore, the influence on $\left[\mathrm{Ca}^{2+}\right] \mathrm{i}$ was accompanied by both an increase in inositol trisphosphate accumulation and a stimulation of cAMP accumulation in these latter cells [210]. It was interesting to note that in these cells the H2R-stimulated calcium and inositol trisphosphate responses were both inhibited by cholera toxin treatment, whereas cholera toxin produced the expected increase in cAMP levels [208, 210]. H2Rs release $\mathrm{Ca}^{2+}$ from intracellular calcium stores in single parietal cells [211] and no effect of H2R agonists was observed on intracellular calcium levels or inositol phosphate accumulation in CHO cells transfected with the H2R of human [144]. Thus, the effect of $\mathrm{H} 2 \mathrm{R}$ stimulation on intracellular $\mathrm{Ca}^{2+}$ signaling may be highly cell-specific.

The stimulation of $\mathrm{H} 2 \mathrm{R}$ produces both inhibition of $\mathrm{P} 2 \mathrm{u}-$ receptor-mediated arachidonic acid release and an increase in cAMP accumulation in $\mathrm{CHO}$ cells transfected with the rat H2R [171]. However, Traiffort et al. [171] had demonstrated that the effect on phospholipase A2 activity (i.e., arachidonic acid release) was not mimicked by forskolin, PGE1, or 8bromo-cAMP, suggesting a mechanism of activation that is independent of cAMP-mediated protein kinase A activity. However, inhibitory effects of H2R stimulation were observed on phospholipase A2 activity in CHO cells transfected with the human H2R [200]. Thus, these cAMPindependent effects might depend on the level of receptor expression or subtle differences between clonal cell lines. 


\section{Histamine H3-Receptor}

\section{Cellular Distribution and Functional Characterization}

The function of histamine as neurotransmitter has been proved with the discovery of the H3R. It was mainly involved in brain functions, also the peripheral effect of histamine on mast cells via H3Rs, which mainly involves the nervous system, and might be connected to a local neuronmast cell interaction [212]. Its involvement in cognition, sleep-wake status, energy homeostatic regulation and inflammation had attracted many pharmaceutical researches for numerous, so far unmet, therapeutic approaches in different peripheral, but mainly central diseases [213, 214]. A recent study had reported that it is presynaptically located as autoreceptor controlling the synthesis and release of histamine [215]. It was observed that $\mathrm{H} 3$-autoreceptor activation stimulates the negative feedback mechanism that reduces central histaminergic activity [216]. H3R's heterogeneity in binding and its functional studies has well been documented, and suggested more than one H3R subtype. This assumption had been confirmed by demonstration of several H3R variants, generated from the complex H3R gene by alternative splicing. The three functional isoforms have been found in the rat, and they all vary in length of the $3^{\text {rd }}$ intracellular loop, their distinct central nervous system (CNS) localization, and differential coupling to adenylate cyclase and MAPK signaling. Similar results in case of humans were obtained [217-219].

Thus, numerous isoforms are found in different species and different tissues leading to the assumption that signaling fine-tuning may be controlled via receptor oligomerization or formation of isoforms [220].

$\mathrm{H} 3 \mathrm{R}$ is anatomically localized primarily to the CNS with prominent expression in basal ganglia, cortex hippocampus and striatal area. In the periphery, H3R can be found with low density in gastrointestinal, bronchial and cardiovascular system [221]. The high apparent affinity of $\mathrm{R}-(\alpha)$ methylhistamine for the H3R has enabled the use of this compound as a radiolabeled probe (Table 1) [222]. In rat cerebral cortical membranes, this compound (R- $(\alpha)$ methylhistamine) has been used to identify a single binding site, and which in phosphate buffer has the important pharmacological characteristics of the H3R [222, 223]. In rat brain membranes, $[3 \mathrm{H}] \mathrm{R}-(\alpha)$-methylhistamine binds with high affinity $\left(\mathrm{K}_{\mathrm{D}} 50.3 \mathrm{nM}\right)$, although its binding capacity is low ( $30 \mathrm{fmol} / \mathrm{mg}$ protein) [222]. It was significantly notable that the autoradiographic studies with $[3 \mathrm{H}] \mathrm{R}-(\alpha)-$ methylhistamine have described the presence of specific thioperamide-inhibitable binding in several rat brain regions, especially cerebral cortex, striatum, hippocampus, olfactory nucleus, and the bed nuclei of the stria terminalis, which receive ascending histaminergic projections from the magnocellular nuclei of the posterior hypothalamus [222, 224]. In human brain and the brain of nonhuman primates, the H3Rs have also been visualized [225]. H3R binding has also been characterized using $[3 \mathrm{H}] \mathrm{R}-(\alpha)$-methylhistamine in guinea pig lung [222], guinea pig cerebral cortical membranes [226], guinea pig intestine and guinea pig pancreas [227]. Na-methylhistamine as a radiolabeled probe had proved successful for the H3R (Table 1). The relative agonist activity of $\mathrm{N} \alpha$-methylhistamine (with respect to histamine) was significantly similar for all three histamine receptor (HRs) subtypes, but the binding affinity of histamine and $\mathrm{N} \alpha$-methylhistamine for the H3R was several orders of magnitude higher than for either H1- or H2-receptors [23, 131]. $\mathrm{N \alpha}$-methylhistamine can identify high-affinity H3R sites in both rat [228, 230] and guinea pig [227] brain. The binding of H3-receptor-agonists to H3Rs in brain tissues was found to be regulated by guanine nucleotides, implying its relation to heterotrimeric G-proteins [222, 223, 228, 229]. Also the binding of H3R agonists appears to be more sensitive to several cations. For example magnesium $\left(\mathrm{Mg}^{2+}\right)$ and sodium $\left(\mathrm{Na}^{+}\right)$ions inhibit [3H]R-( $\left.\alpha\right)$-methylhistamine binding in guinea pig and rat brain [226], and the presence of calcium $\left(\mathrm{Ca}^{2+}\right)$ ions has been shown to reveal heterogeneity of agonist binding [223]. It is important to note that the inhibitory effect of sodium $\left(\mathrm{Na}^{2+}\right)$ ions on agonist binding means higher $\mathrm{B}_{\max }$ values that were usually obtained in sodium-free Tris buffers compared with the $\mathrm{Na} / \mathrm{K}$ phosphate buffers [228]. The multiple histamine $\mathrm{H} 3 \mathrm{R}$ subtypes exist in rat brain (termed $\mathrm{H}_{3 \mathrm{~A}}$ and $\mathrm{H}_{3 \mathrm{~B}}$ ) on the basis of $\left[{ }^{3} \mathrm{H}\right] \mathrm{N}^{\alpha}$ methylhistamine binding in rat cerebral cortical membranes in $50 \mathrm{mM}$ Tris buffer (Table 1) [230]. Based on these conditions, the selective histamine $\mathrm{H} 3$-antagonist thioperamide can discriminate two affinity-binding states [230]. However, Heterogeneity of thioperamide binding was sodium $\left(\mathrm{Na}^{2+}\right)$ ions concentration dependent or depends on guanine nucleotides within the incubation medium [228]. Thus, in the presence of $100 \mathrm{mM}$ sodium chloride, thioperamide binding conforms to a single binding isotherm [228], and H3R can exist in different conformations for which thioperamide, but not agonists or other H3R-antagonists (clobenpropit) can discriminate. This suggests that the equilibrium between these conformations is altered by guanine nucleotides or sodium $\left(\mathrm{Na}^{2+}\right)$ ions [228]. If this speculation is correct, it is likely that the different binding sites represented resting, active, or G-protein-coupled conformations of the H3R. Furthermore, if thioperamide preferentially binds to uncoupled receptors, then this compound should exhibit negative efficacy in functional assays. Radiolabeled H3R antagonists [125I]iodophenpropit, has been used to label histamine H3Rs in rat brain membranes (Table 1) [231]. The inhibition curves for iodophenpropit and thioperamide were consistent with interaction with a single binding site, but H3R agonists were found to be able to discriminate both high- [4 $\mathrm{nM}$ for R- $(\alpha)$ methylhistamine] and low- $[0.2 \mathrm{mM}$ for R- $(\alpha)$-methylhistamine] affinity binding sites [231]. [ $\left.{ }^{3} \mathrm{H}\right] \mathrm{GR} 16820$ and $\left[{ }^{125} \mathrm{I}\right]$ iodoproxyfan have been proved useful as high-affinity radiolabeled H3R-antagonists [232, 233]. In rat striatum, in the IUPHAR classification of histamine receptors 267 presence of guanine nucleotides such as guanosine 59O- (3thiotriphosphate) (GTPgS), 40\% of the binding sites exhibited a 40-fold lower affinity for H3-agonists, providing further evidence for a potential linkage of H3Rs to G-proteins. In rat brain membranes, $\left[{ }^{3} \mathrm{H}\right]$ thioperamide and $\left[{ }^{3} \mathrm{H}\right] 5-$ methylthioperamide, both have been used to label H3R [234]. However, $\left[{ }^{3} \mathrm{H}\right]$ thioperamide was shown to bind additionally to low affinity, high-capacity, non H3R sites [234]. The localization of H3Rs had come out from functional studies, primarily involving inhibition of neurotransmitter release. The H3R was first characterized as an auto receptor regulating histamine synthesis and release from rat cerebral hippocampus, cortex, and striatum [222, 235]. In human 
cerebral cortex, the H3R-mediated inhibition of histamine release has also been demonstrated [235]. Differences in the distribution of H3R binding sites and the levels of histidine decarboxylase (an index of histaminergic nerve terminals) suggested at an early stage that H3Rs were not confined to histamine-containing neurons within the mammalian CNS $[222,236]$. It has been documented by the observations that H3Rs can regulate neurotransmitter release in mammalian brain as serotonergic, noradrenergic, cholinergic, and dopaminergic [237-240]. H3R activation inhibits the firing of the histamine-neurons in the posterior hypothalamus by a mechanism different from auto-receptor functions found on other aminergic nuclei, and presumably a block of $\mathrm{Ca}^{2+}$ current [241]. H3Rs were found to regulate the release of sympathetic neurotransmitters in guinea pig mesenteric artery [242], human saphenous vein [243], guinea pig atria [244, 245], and human heart [246].

An important inhibitory effect of H3R activation on release of neuropeptides (tachykinins or calcitonin generelated peptide) from sensory $\mathrm{C}$ fibers has been investigated from airways [247], meninges [248], skin [249], and heart [250]. The modulation of acetylcholine, capsaicin, and substance $\mathrm{P}$ effects by H3Rs in isolated perfused rabbit lungs has also been reported [251]. There was evidence that H3R activation can inhibit the release of neurotransmitters from nonadrenergic- noncholinergic nerves in guinea pig bronchioles [252] and ileum [253]. In guinea pig ileum, the H3Rantagonists betahistine and phenylbutanoylhistamine were much less potent as inhibitors of H3R-mediated effects on nonadrenergic-noncholinergic transmission than they were as antagonists of histamine release in rat cerebral cortex [253].

A similar low potency has been investigated for betahistine and phenylbutanoyl histamine antagonists for antagonism of H3R-mediated $\left[{ }^{3} \mathrm{H}\right]$ acetylcholine release from rat entorhinal cortex [239], and antagonism of H3R-mediated 5hydroxytryptamine release from porcine enterochromaffin cells [254]. These investigations provide possible support for the existence of distinct H3R subtypes and it had been shown that phenylbutanoylhistamine can inhibit $\left[{ }^{3} \mathrm{H}\right]$ acetylcholine release from rat entorhinal cortex slices, and synaptosomes by a nonhistamine receptor mechanism [255]. Therefore, the potency of phenylbutanoylhistamine as H3R-antagonist in those preparations can be highly underestimated because of the additional nonspecific activities of the drug [255]. The inhibitory effect of H3-receptor stimulation on 5-HT release from porcine enterochromaffin cells in strips of small intestine [254] provides evidence for H3-receptors regulating secretory mechanisms in non-neuronal cells. Hence, it can be concluded that H3R may be present in gastric mast cells or enterochromaffin cells and exert an inhibitory effect on histamine release and gastric acid secretion. In conscious dogs, H3R activation had been observed to inhibit gastric acid secretion [256], and in isolated rabbit fundic mucosal cells. An autoregulation of histamine synthesis by H3R had also been investigated [257]. It had been demonstrated that H3R relaxes rabbit middle cerebral artery by an endotheliumdependent pathway involving both nitric oxide and prostanoid release $[258,259]$. H3-receptor stimulation can activate adrenocorticotropic hormone release from the pituitary cell line AtT-20 [260]. Therefore, H3R provides constitutive properties, which means part of the receptor population spontaneously undergoes allosteric transition leading to a conformation, to which $\mathrm{G}$ protein can bind [261, 262], and also H3R-knock out mice manifest an obese phenotype (characterized through increased body weight, food intake, adiposity, and reduced energy expenditure). Recently, it has been observed that H3R express insulin and leptin resistance as well as a diminution of the energy homeostasis-associated genes UCP1 and UCP3 [263]. The chemical structure of specific H3R-antagonists and -agonists are shown in Figs. (7, 8).

\section{Structural Biology of Receptor}

The H3-receptor is also G protein-coupled (GPCR) and had been cloned [22]. Its gene consists of 4 exons spanning $5.5 \mathrm{~kb}$ on chromosome 20 (20q13.33) in humans (Table 2). Structural studies of H3R are very limited and there are only few reports on its purification studies. By using $\left[{ }^{3} \mathrm{H}\right]$ histamine as a radioligand, the solubilization of a H3R protein from bovine whole brain has been reported and then Size-exclusion chromatography has revealed an apparent molecular mass of $220 \mathrm{kDa}$ [229]. However, because the solubilized receptor retained its guanine nucleotide sensitivity and it is likely that the molecular mass of $220 \mathrm{kDa}$ represents a complex of receptor, G-protein, and digitonin [229]. Cherifi et al. [264] have reported the solubilization (with Triton X-100) and purification of the H3-receptor protein from the human gastric tumoral cell line HGT-1. After gel filtration and sepharose-thioperamide affinity chromatography, protein has been purified with a molecular mass of approximately $70 \mathrm{kDa}$ (see Table 2).

\section{Signaling Mechanisms}

The signal mechanisms used by the H3R remain largely subject to hypothesis, but there is increasing evidence to suggest that this receptor belongs to the G-protein-coupled receptors (Gi/o) (Table 2), and its activation leads to inhibition of cAMP formation, accumulation of $\mathrm{Ca}^{2+}$ and stimulation of mitogen-activated protein kinase (MAPK) pathway [212], see Fig. (4). This evidence had been obtained from ligand-binding studies that involve the modulation by guanine nucleotides of H3R-agonist binding [223, 226, 228-230] and H3R-agonist inhibition of H3R-antagonist binding [231, $233,265]$. The direct evidence for a functional H3R-Gprotein linkage came from studies of $\left[{ }^{35} \mathrm{~S}\right] \mathrm{GTPgS}$ binding to rat cerebral cortical membranes [266]. In rat cerebral cortical membranes, the presence of H1R- and H2R-antagonists $(0.1$ $\mathrm{mM}$ mepyramine and $10 \mathrm{mM}$ titotidine), and both $\mathrm{R}-(\alpha)$ methylhistamine and $\mathrm{N}-(\alpha)$-methylhistamine generated a concentration dependent stimulation of [35S]GTPgS binding $\left(\mathrm{EC}_{50}=0.4\right.$ and $\left.0.2 \mathrm{nM}\right)$ [266]. Notably, this response was inhibited via pretreatment of membranes with pertussis toxin, and implying a direct coupling to a Gi or Go protein [266]. The evidence of pertussis toxin-sensitive G-proteins in the response to H3R stimulation came from studies of H3R signaling in human and guinea pig heart [244, 246]. H3Ractivation appeared to lead to an inhibition of N-type $\mathrm{Ca}^{2+}$ channels responsible for voltage dependent release of noradrenaline in human and guinea pig heart [244, 246], but several investigations have failed to demonstrate an inhibition of adenylyl cyclase activity in different tissues and cells $[264,267]$ which might suggest that H3Rs couple to Go proteins. 
<smiles>S=C(NC1CCCCC1)N1CCC(c2c[nH]cn2)CC1</smiles>

Thioperamide<smiles>N=C(NCCc1ccc(I)cc1)SCCCc1c[nH]cn1</smiles>

Iodophenpropit

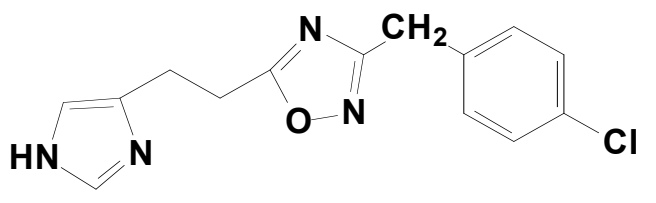

GR 174737

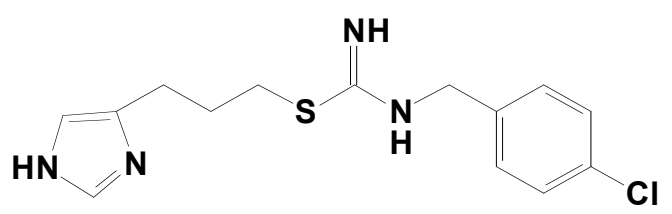

Clobenpropit

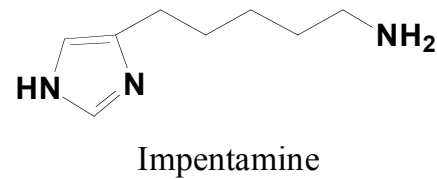

Fig. (7). Chemical structures of some histamine H3-receptor-antagonists.

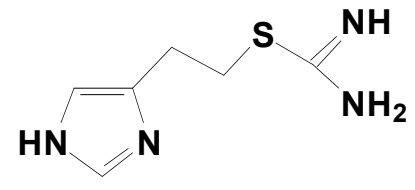

Imetit

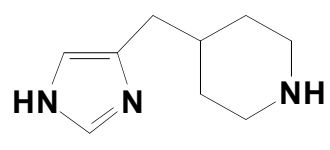

Immepip

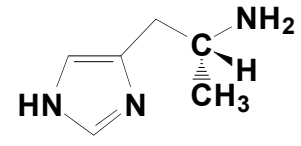

(R)- $\alpha$-Methylhistamine

Fig. (8). Chemical structures of some histamine H3-receptor-agonists.

\section{Histamine H4-Receptor}

\section{Cellular Distribution and Functional Characterization}

The discovery of the H4-receptor adds a new chapter to the histamine story. The H4R is preferentially expressed in intestinal tissue, spleen, thymus, medullary cells, bone marrow and peripheral hematopoietic cells, including eosinophils, basophils, mast cells, T lymphocytes, leukocytes and dendritic cells. However, moderate positive signals have also been detected in brain, spleen, thymus, small intestine, colon, heart, liver and lung. Although first expression studies demonstrated the absence of H4Rs in the central nervous system (CNS), but in situ hybridization studies suggested evidence for their human brain localization in low density. The relatively restricted expression of the H4R provides an important role in inflammation, hematopoiesis and immunity by the regulation of H4R expression via stimuli such as IFN, TNF- $\alpha$ and IL-6, IL-10, and IL-13. Basophils and mast cells express H4R-mRNA. The H4R mediates chemotaxis of mast cells and eosinophils as well as control cytokine release from dendritic cells and T cells. It was demonstrated that the H4R is participated, along with the $\mathrm{H} 2 \mathrm{R}$, in the control of IL-16 release from human lymphocytes. It had also been hypothesized that H4R selective antagonist might be useful in helping to treat anti-inflammatory potency in models of asthma, arthritis, colitis and pruritis. Antagonists, such as JNJ 7777120 , have also been shown to be effective in various model of inflammation. Up to now, very little is known about the biological functions of H4R. There are few reports in the literature, providing evidence for chemotactic activity in mast cells and eosinophils or control of IL-16 production by $\mathrm{CD}^{+}$lymphocytes. It suggests an important role of H4R in the regulation of immune function and offers novel therapeutic potentials for histamine receptor ligands in allergic and inflammatory diseases [268-280]. A recent study showed the role of H4R in mast cell, eosinophil, and T cell function, as well as the effects of its antagonist, JNJ 7777120, in a mouse peritonitis model pointing to a more general role for H4R in inflammation. Selective H4R antagonists like JNJ 7777120 shows potential role in treatment of inflammation in humans. In many diseases such as allergic rhinitis, asthma, and rheumatoid arthritis, conditions where eosinophils and mast cells are involved, H4R antagonists have therapeutic utility [281]. The discovery of H4R and its emerging role in inflammation had spurred new interest for the functions of histamine in inflammation, allergy and autoimmune diseases. Early results in animal models suggest that H4R antagonists may have utility in treating various conditions in humans, in particular, in diseases in which histamine is known to be present and in which H1R antagonists are not clinically effective [282]. Obviously, a better functional characterization of H4R benefits from the exploitation of new, specific tools, such as the recently developed potent and selective nonimidazol H4R antagonist [281]. It can be expected that the role of H4R will be more important in autoimmune disorders, allergic conditions and nociceptive responses in the 


\section{H4-receptor antagonists}

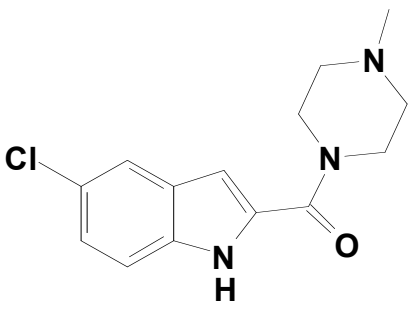

JNJ 7777120

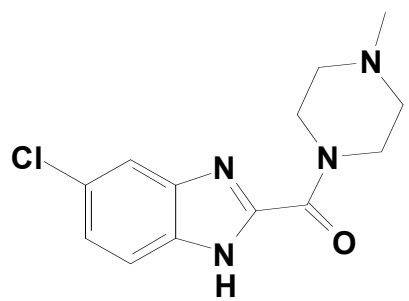

JNJ 10191584<smiles>S=C(NC1CCCCC1)N1CCC(c2c[nH]cn2)CC1</smiles>

Thioperamide (partial H4R-antagonist)

H4-receptor agonists

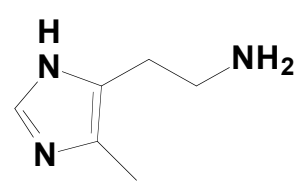

4-Methylhistamine

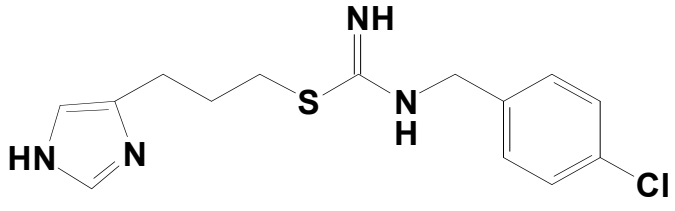

Clobenpropit (partial H4R-agonist)

Fig. (9). Chemical structures of specific H4-receptor-antagonists and -agonists.

near future. The chemical structure of specific H4Rantagonists and -agonists are shown in Fig. (9).

\section{Structural biology of Receptor}

The human H4-receptor gene was mapped to chromosome 18q11.2 which encodes a 390 amino acid and also related to seven transmembrane G-protein coupled receptor. It shares $37-43 \%$ homology (58\% in transmembrane regions) with the H3-receptor and a similar genomic structure. The H4R gene spans more than $21 \mathrm{kbp}$ and contains three exons, separated by two large introns ( $>7 \mathrm{~kb}$ ) (Table 1) with large interspecies variations from $65-72 \%$ homology in sequences. Analysis of the $5^{\prime}$ flanking region did not reveal the canonical TATA or CAAT-boxes. The promoter region contains several putative regulatory elements involved in proinflammatory cytokine signaling pathways. H4Rs are coupled to Gi/o, which initiates various transduction pathways such as inhibition of forskolin-induced cAMP formation, enhanced calcium influx and MAPK activation. In accordance with the homology between the two receptors, several H3R-agonists and antagonists were recognized by the H4R, although with different affinities. It has been observed that H3R-agonist R$\alpha$-methyl histamine acts on H4R with several hundred times less potency. Similar effect has been seen with thioperamide, the classical H3R antagonist which also behave like a H4R antagonist (Table 1), though with a much lower affinity and clobenpropit, also a H3R antagonist, which exerts agonistic activity on H4R [Table 1; 21, 273, 274, 283-286].

Albeit histamine binding to H4R is very similar to that reported for the other histamine receptors (it shows the im- portance of the Asp 94 residue in transmembrane region (TM) 3 and the Glu 182 residue in the TM 5) however, some differences exist and these were exploited to design specific tools. Mouse, rat and guinea pig H4Rs have been cloned and characterized and were found to be only 68,69 , and $65 \%$ homologous respectively to their human counterpart. These studies have revealed substantial pharmacological variations between species, with higher affinity of histamine for human and guinea pig receptors than for their rat and mouse equivalents [287].

\section{Signaling Mechanisms}

The signal mechanisms used by the H4R remain highly subject to the G-protein-coupled receptors $(\mathrm{Gi} / \mathrm{o})$, and its activation leads to an inhibition of adenylyl cyclase and downstream of cAMP responsive elements (CRE) as well as activation of mitogen-activated protein kinase (MAPK) and phospholipase $\mathrm{C}$ with $\mathrm{Ca}^{2+}$ mobilization (Table 2); see Fig. (4).

\section{HISTAMINE: NON-CLASSICAL BINDING SITES}

\section{A. Cytochrome P450}

The human cytochrome P450 (CYP450) superfamily comprises 57 genes encoding heme-containing enzymes, which are found in the liver as well as in extrahepatic tissues (adrenals, and peripheral blood leukocytes), where they can be stimulated by various stimuli [288, 289] (Fig. 10). They are not only involved in metabolism of large number of foreign substances, but also play an important role in diverse physiological processes [generation, transformation or inac- 


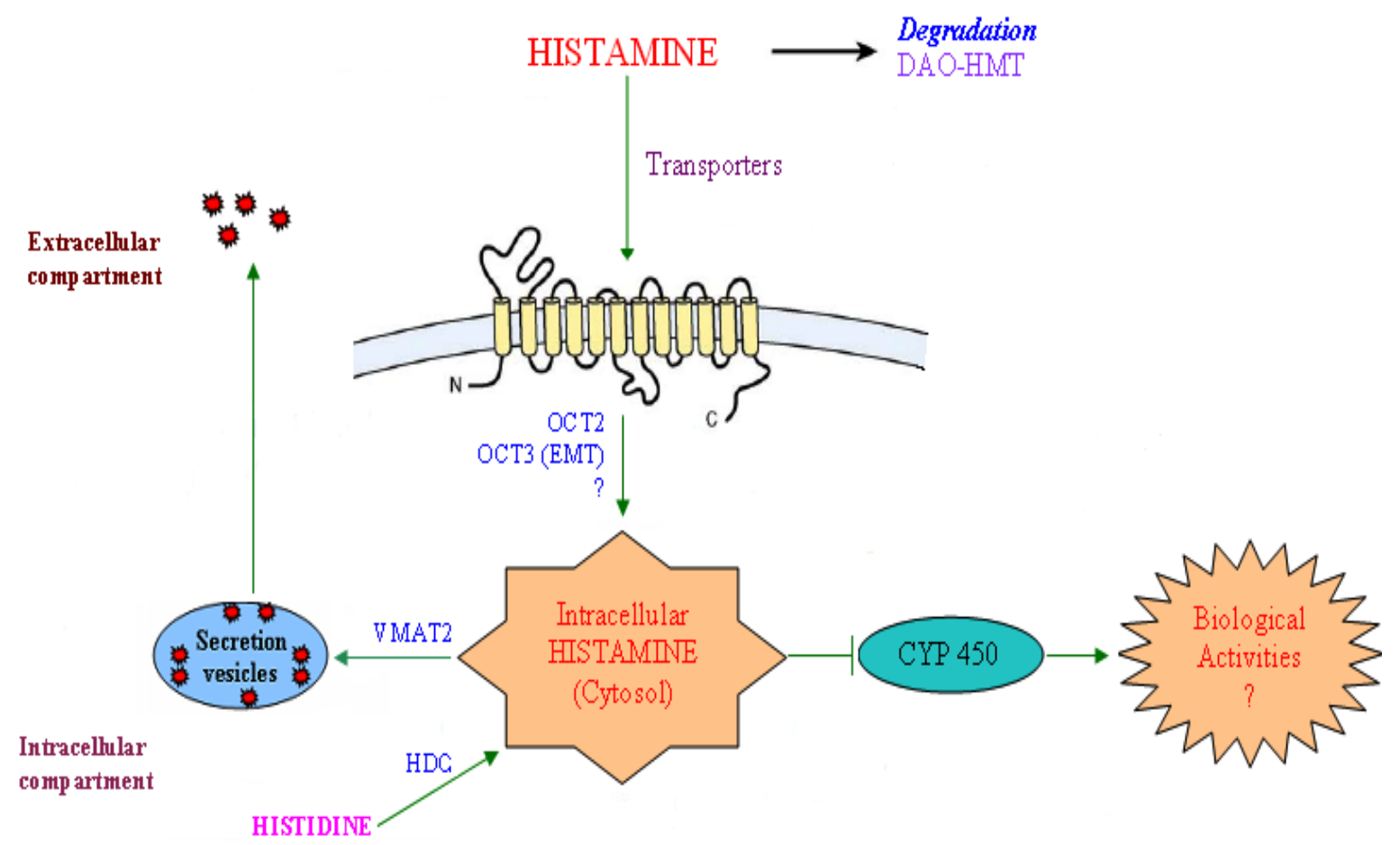

Fig. (10). The non-classical histamine binding sites and their main signaling pathways such as DAO: diamine oxidase; HMT: histamine methyl transferase; OCT: organic cation transporter; HDC: histidine decarboxylase; CYP 450: cytochrome P450; VMAT: vesicular monoamine transporter.

tivation of endogenous ligands (steroids and lipids)], which are involved in cell regulation [290].

Binding of histamine to CYP450 had been shown by Branders, who proposed a second messenger role for intracellular histamine via this binding site. This hypothesis was mainly based on a finding that $\mathrm{N}, \mathrm{N}$ diethyl-2-(4(phenylmethyl)phenoxy) ethanamine (DPPE), an arylalkylamine analogue of tamoxifen inhibits the binding of histamine to CYP450 [291]. DPPE allosterically modify histamine binding to the heme moiety of CYP450 enzymes and inhibited platelet aggregation, as well as lymphocyte and hematopoietic progenitor proliferation [292, 293]. The effect of DPPE on histamine binding was found to be highly complicated and depends on the nature of the P450 enzymes. Thus, it inhibits the action of histamine on CYP2D6 and CYP1A1, which enhances its effect on CYP3A4 and does not affect CYP2B6 [294]. The heme moiety of CYP450 binds to several histamine antagonists [295, 296], particularly H3R antagonists (thioperamide, clobenproprit and ciproxyfan) [297]. This property explains some effects of these antagonists, when used at high doses. Notably, histamine interacts with CYP450 and it has been demonstrated that CYP2E1 and CYP3A were upregulated in histidine decarboxylase (HDC)-deficient mice [298].

\section{B. Transporters of Histamine}

Histamine (2-(1H-imidazol-4-yl) ethanamine) is synthesized in the cytosol and requires a specific transport into secretory vesicules where it is sequestered. Vesicular monoamine transporters (VMATs) are proteins, which accomplish this specific task for several neurotransmitters [299] (Fig. 10). The two subtypes of monoamine transporters are VMAT1 and VMAT2 (that have been cloned and character- ized) but VMAT2 can transport histamine. Vesicular monoamine transporter 2 (VMAT2) had been cloned from rat and human brain, bovine adrenal medulla and a basophilic leukemia cell line. When histamine biosynthesis was enhanced then its expression was found to be up regulated by several stimuli. The increased VMAT2 expression in IL-3dependent cell lines was enhanced with enhanced histamine synthesis in response to calcium $\left(\mathrm{Ca}^{2+}\right)$ ionophore [300]. VMAT2 is responsible for the transport of histamine into secretory granules of enterochromaffin-like (ECL) cells. The gene expression of VMAT2 was found to be modulated via cytokines, either positively (TGFa) or negatively (IL-1 and TNF- $\alpha$ ) [301]. VMAT2-deleted granules do not release histamine upon activation, even though granule cell fusion does still occur [302]. The bone marrow-derived mast cells from histidine decarboxylase (HDC)-deleted mice are completely devoid of endogenous histamine but can take up the mediator from histamine-supplemented medium and store it in secretory granules. Hence, two transporters are essential to:

1. insure the passage across the plasma membrane, and

2. cross the vesicular membrane.

First transporter has not been identified yet, but the second transporter seems to be vesicular monoamine transporter 2 (VMAT2). The non-neuronal monoamine transporters that actively remove monoamines from extracellular space have been described as organic cation transporter 1 (OCT1), OCT2, and extraneuronal monoamine transporter (EMT). EMT was also designated as OCT3. The expression of OCT1 was found to be restricted to liver, kidney and intestine, OCT2 in brain and kidney, while EMT showed a broad tissue distribution. It has been established that OCT1 cannot transport histamine, conversely to OCT2 and EMT for which 
it is a good substrate [303]. Thus, EMT appeared to be a good candidate as histamine transporter in mast cells and basophils, accounting for their capacity to take up the mediator from the environment.

\section{IMMUNE REGULATION BY HISTAMINE IN IM- MUNOMODULATION AND ALLERGIC INFLAM- MATION}

Histamine exerts a very important immunomodulatory effect via H1-, H2-, H3-, and H4-receptors [1, 20, 128, 188, 189, 270, 304; Table 3]. According to the cell differentiation stage and microenvironment influences, the receptors expression changes. Histamine shows proinflammatory or antiinflammatory effects, depending on the predominance of the type of histamine receptor (H1R, H2R, H3R \& H4R) and on the experimental system studied. Histamine had proinflammatory activity through the H1R, and is involved in the development of various aspects of antigen-specific immune response including the maturation of dendritic cells (DCs) and the modulation of the balance of type 1 helper (Th1) T cells and type 2 helper (Th2) T cells. Histamine blocks humoral immune responses by means of a specific mechanism in which it induce an increase in the proliferation of Th1 cells and in the production of interferon $\gamma$ (IFN- $\gamma$ ). Histamine also stimulates the release of proinflammatory cytokines and lysosomal enzymes from human macrophages and shows the capacity to influence the activity of immune cells including mast cells, basophils, eosinophils, fibroblasts, lymphocytes, neutrophils, epithelial and endothelial cells. The role of histamine in autoimmunity and malignant disease through the H1R is well documented [20, 128]. Histamine also plays a pivotal role in allergic inflammation which is a complex network of cellular events and involves redundant mediators and signals. Histamine is released from the granules of mast cells and basophils (FceRI cells) along with several mediators such as tryptase, leukotrienes, prostaglandins, and other newly generated mediators. Histamine was found in relatively large $(\mu \mathrm{g})$ quantities per 1 million cells, in contrast to leukotrienes and other mediators (which are present in picograms), after allergen challenge in sensitized persons. Most of the potent effects of histamine in allergic inflammation occur through H1Rs [1, 13, 20; Table 3], while hypotension, flushing, headache, and tachycardia occur both by the H1- and H2-receptors in the vasculature [305]. Whereas, nasal congestion and cutaneous itch occurs both by the H1- and H3- receptors [306, 307]. Histamine also acts as a contributor to the late allergic response by generating a stimulatory signal for the production of cytokines, the expression of cell adhesion molecules and class II antigens.

\section{EFFECT OF HISTAMINE IN IMMUNE CELLS WITH RESPECT TO ALLERGIC DISEASES}

Histamine's classical effects, expressed at the organ level, have been documented and were highly emphasized in allergies and autoimmune diseases. Histamine directly or indirectly influences the activity of various inflammatory/effector/immunologic cell types involved in the pathogenesis of several diseases. Indeed, several studies have suggested that histamine receptors (HRs) are expressed on mast cell and basophils; lymphocytes; neutrophils; monocytes, macrophages and dendritic cells (DCs); eosinophils; epithe- lial cells; endothelial cells, and therefore modulate the function of these cells in immune system.

\section{A. Mast Cells and Basophils}

Recent studies shed light on the potent role of histamine in mast cells and basophils, both types of cells can themselves be modulated by histamine as they express H1-, H2and H4-receptors [271, 308, 309]. The peritoneal and skin mast cells exhibited aberrant granules with very low electron density, in HDC-deficient mice, which indicated the drastic decrease in the granule contents including granule proteases and sulfated proteoglycans [310]. The critical roles of histamine in cutaneous and systemic anaphylaxis have been suggested by using the HDC-deleted mice $[311,312]$ and it remained a possibility that diminished granule constituents, such as proteases, make contribution to the relief of anaphylaxis in the mutant mice. How histamine regulates allergic responses by maturation of tissue mast cells requires to comprehend detailed studies on the effect of absence of histamine on mast cell function. Impact of histamine was also demonstrated in the migration of mast cells which was mediated exclusively through the H4R [271]. It has been shown that histamine acting through H4Rs can stimulate chemotaxis of murine mast cells in vitro [271] and lead to changes in tissue localization in vivo [281]. A hematopoietic organ, bone marrow, contains certain types of cells which can produce histamine in response to IL-3 [30, 313]. The role of IL3 -sensitized histamine synthesis in bone marrow remains to be clarified [39], however, a study suggested a unique circuit of newly synthesized histamine and its implication in basophil precursors [314]. It has been documented that bidirectional transport of histamine is facilitated largely through organic cation transporter 3 (OCT3) in the plasma membranes of the FceRI', c-kit ${ }^{-}$bone marrow cells. It had been demonstrated that intracellularly stimulated histamine in the organic cation transporter 3 (OCT3)-deleted cells has suppressive impacts on expression of HDC, IL-4, and IL-6. This suggests not only the feedback inhibition of histamine synthesis but also the suppression of Th2 cytokine production through immature basophils [303, 315]. In addition, histamine receptor binding studies with specific receptor antagonists have suggested that basophils express predominantly $\mathrm{H} 2 \mathrm{R}$, and these were involved in the regulation of $\mathrm{IgE}-$ stimulated histamine release, as demonstrated through increased histamine release in the presence of anti-IgE and cimetidine (a H2R antagonist) but not in the presence of antiIgE and thioperamide (a H3R antagonist) [316-318]. H2Rs in mast cells show various effects such as inhibition of histamine release and modulation of cytokine production [319]. It has been suggested that H3R functions on mast cells but many of these properties may be attributed to the H4R as the ligands used were not specifically selective. H3R expression was not detected in some types of mast cells [271].

\section{B. Lymphocytes}

The expression of histamine receptors (HRs) on the cell surface of immunocompetent cells, including lymphocytes (B-cells and T-cells) and their effects mediated by receptors (HRs) have been published in several studies and significantly reviewed [320] (Fig. 11). It has been concluded that both histamine receptors $(\mathrm{H} 1$ and $\mathrm{H} 2)$ are present on the 
Table 3. Immunopharmacological Profiles of Histamine Receptor Subtypes

\begin{tabular}{|c|c|c|c|c|}
\hline Characteristics & Histamine H1R & Histamine H2R & Histamine H3R & Histamine H4R \\
\hline${ }^{\mathrm{a}}$ General function & $\begin{array}{l}\text { Increased pruritus, pain, } \\
\text { vasodilation, vascular per- } \\
\text { meability, hypotension; flush- } \\
\text { ing, headache, tachycardia, } \\
\text { bronchoconstriction, stimula- } \\
\text { tion of airways, vagal stimu- } \\
\text { lation of airway vagal recep- } \\
\text { tors; decreased atrio- } \\
\text { ventricular-node conduction } \\
\text { time. }\end{array}$ & $\begin{array}{l}\text { Increased gastric acid secre- } \\
\text { tion, vascular permeability, } \\
\text { hypotension, flushing, head- } \\
\text { ache, tachycardia, chro- } \\
\text { notropic and inotropic activ- } \\
\text { ity, bronchodilatation, mu- } \\
\text { cus production (airway). }\end{array}$ & $\begin{array}{l}\text { Prevents excessive } \\
\text { bronchoconstriction; } \\
\text { mediates pruritus (no } \\
\text { mast-cell involvement). }\end{array}$ & $\begin{array}{l}\text { Differentiation of mye- } \\
\text { loblasts and promyelo- } \\
\text { cytes. }\end{array}$ \\
\hline $\begin{array}{l}{ }^{a} \text { Function in immune } \\
\text { modulation and allergic } \\
\text { inflammation }\end{array}$ & $\begin{array}{l}\text { Increases release of histamine } \\
\text { and other mediators; in- } \\
\text { creases cellular adhesion } \\
\text { molecule expression and } \\
\text { chemotaxis of eosinophils } \\
\text { and neutrophils; increases } \\
\text { antigen-presenting cell capac- } \\
\text { ity, co-stimulatory activity on } \\
\text { B cells; increases cellular } \\
\text { immunity (Th1), IFN- } \gamma \text {, } \\
\text { autoimmunity. Decreases } \\
\text { humoral immunity and IgE } \\
\text { production. }\end{array}$ & $\begin{array}{l}\text { Decreased eosinophil and } \\
\text { neutrophil chemotaxis; } \\
\text { induction of interleukin-10, } \\
\text { suppression of interleukin- } \\
12 \text { by dendritic cells; } \\
\text { development of Th2 or } \\
\text { tolerance inducing dendritic } \\
\text { cells; induction of humoral } \\
\text { immunity; suppression of } \\
\text { Th2 cells and cytokines; } \\
\text { indirect role in allergy, } \\
\text { autoimmunity, malignant } \\
\text { disease, and graft rejection. }\end{array}$ & $\begin{array}{l}\text { Probably involved in control } \\
\text { of neurogenic inflammation } \\
\text { through local neuron-mast } \\
\text { cell feedback loops; proin- } \\
\text { flammatory activity; in- } \\
\text { creased APC (antigen- } \\
\text { presenting cell) capacity. }\end{array}$ & $\begin{array}{l}\text { Increased } \mathrm{Ca}^{2+} \text { flux in } \\
\text { human eosinophils; } \\
\text { increased eosinophil } \\
\text { chemotaxis; increases } \\
\text { IL-16 production (H2- } \\
\text { receptor also involved). }\end{array}$ \\
\hline${ }^{\mathrm{b}}$ Physiological relevance & $\begin{array}{l}\text { Cycle of sleeping and wak- } \\
\text { ing, food intake, thermal } \\
\text { regulation, emotions and } \\
\text { aggressive behavior, locomo- } \\
\text { tion, memory, and learning, } \\
\text { contraction of smooth mus- } \\
\text { cles. }\end{array}$ & $\begin{array}{l}\text { Neuroendocrine, gastric acid } \\
\text { secretion. }\end{array}$ & $\begin{array}{l}\text { Presynaptic heteroreceptor; } \\
\text { decreased histamine, dopa- } \\
\text { mine, serotonin, noradrena- } \\
\text { line and acetylcholine release, } \\
\text { sleep, food intake. }\end{array}$ & Chemotaxis. \\
\hline $\begin{array}{l}{ }^{\mathrm{b}} \text { Pathophysiological rele- } \\
\text { vance }\end{array}$ & Allergic reaction. & Gastric ulcer. & $\begin{array}{l}\text { Cognitive impairment, sei- } \\
\text { zure, metabolic syndrome? }\end{array}$ & $\begin{array}{l}\text { Inflammation, immune } \\
\text { reaction }\end{array}$ \\
\hline${ }^{\mathrm{a}, \mathrm{b}}$ Antagonists & $\begin{array}{l}\text { Clinically usable } \\
\text { (Mepyramine, chlor- } \\
\text { pheniramine, astemizole, } \\
\text { terfenadine, loratidine, } \\
\text { triprolidine, diphenhy } \\
\text { dramine, cetirizine, desl- } \\
\text { oratidine, fexofenadine) }\end{array}$ & $\begin{array}{l}\text { Clinically usable (Ci- } \\
\text { metidine, zolantidine, } \\
\text { tiotidine, femotidine, } \\
\text { nizatidine, and ranitidine) }\end{array}$ & $\begin{array}{l}\text { Clobenpropit, Iodophenpro- } \\
\text { pit, } \\
\text { Thioperamide }\end{array}$ & $\begin{array}{l}\text { JNJ 7777120, } \\
\text { JNJ } 10191584\end{array}$ \\
\hline
\end{tabular}

lymphocytes but there is only few data available on the functional significance of the H1R and the distribution of H2R on lymphocyte subsets in general, signaling through the H1R was associated with enhancement and signaling through the $\mathrm{H} 2 \mathrm{R}$ with inhibition of lymphocyte responses. It has been suggested by several studies that histamine and its derivatives can inhibit the immune response by enhancing the activity of $\mathrm{T}$ suppressor cells through $\mathrm{H} 2 \mathrm{R}$ and natural suppressor cells via H1R [321, 322]. The impacts of histamine on T helper lymphocytes are differential and complex; see in Fig. (11). T lymphocytes, mainly $T$ helper lymphocytes, play a significant role in the pathogenesis of atopic asthma. Helper $\mathrm{T}$ lymphocytes can be divided into two subsets ( $\mathrm{T}$ helper type 1 cells (Th1) and Th2) based on their cytokine profile and distinct functions and both the subsets play distinctive roles in the development, initiation, and regulation of the immune response. Th1 cells were found to be responsive in delayed type hypersensitivity (DTH) and cytotoxic response, while Th2 cells were involved in allergic disease via activating B-lymphocytes and regulating antibody (IgG and IgE) secretion; see in Fig. (11). Th1 cells secrete important cytokines as interleukin (IL)-2, IFN- $\gamma$, IL-3, and granulocyte monocyte colony stimulating factor (GM-CSF), while Th2 cells secrete cytokines such as IL-3, IL-4, IL-5, IL-10, IL-13, and GM-CSF. Histamine downregulates the proliferation of Th1 cells (which control cytotoxic response and delayedtype hypersensitivity) and upregulates the proliferation of Th2 cells (which regulate allergic disease and asthma) [323].

Histamine also regulates the development of an allergic state by enhancing the secretion of Th2 cytokines such as IL4, IL-5, IL-10 and IL-13 and by inhibiting the production of Th1 cytokines IL- 2 and IFN- $\gamma$ and monokine IL-12 [324330]. It had been demonstrated in several studies that histamine dose-dependently upregulate the secretion of Th2 cytokines (IL-5, IL-10, and IL-13) and down regulate the secretion of Th1 cytokines (IL-2 and IFN- $\gamma$ ) in cloned murine T helper cells [327-329]. It has also been demonstrated that Th1 and Th2 cells express distinct surface histamine receptor (HR) patterns (Th1 cells that express predominantly H1R and Th2 cells express H2R). Histamine increases Th1-type responses by triggering $\mathrm{H} 1 \mathrm{R}$ and negatively regulates both Th1 and Th2-type responses by $\mathrm{H} 2 \mathrm{R}$ as suggested by enhanced release of tumour necrosis factor (TNF)- $\alpha$ and de- 


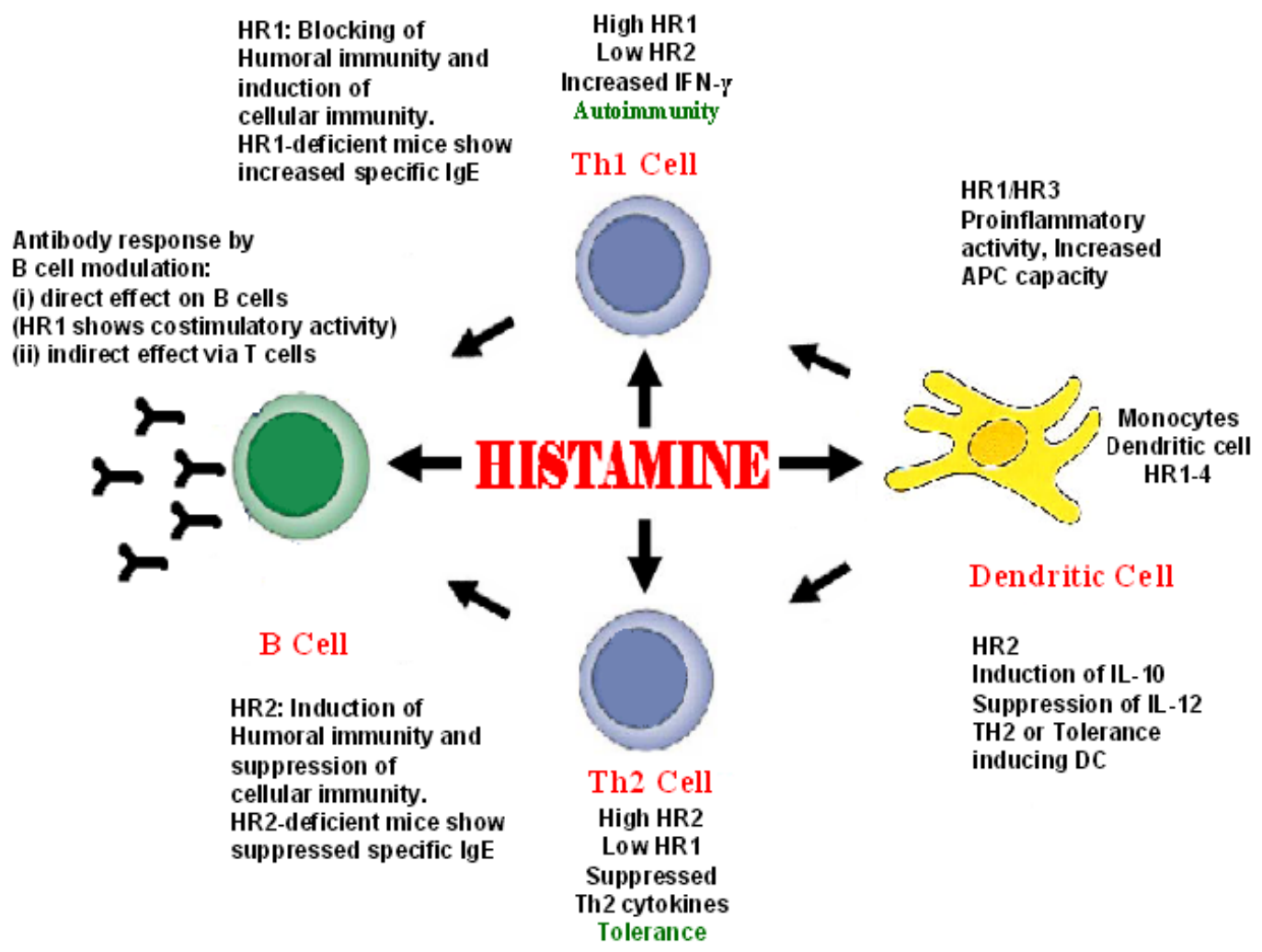

Fig. (11). Histamine regulates monocytes, dendritic cells, $\mathrm{T}$ cells and B cells in lymphatic organs and subepithelial tissues in allergic inflammation. Monocytes and dendritic cells express all four known histamine receptors (HR1, HR2, H3R and HR4). HR1 and HR2 induce proinflammatory activity and enhanced antigen presenting cell capacity, whereas HR2 plays an important suppressive role on monocytes and monocyte-derived dendritic cells (MDDC).

creased release of interleukin (IL)-4 and IL-13, respectively [331]. The differential expression of these cells to histamine is a result of the type of intracellular signals generated via histamine activation. Notably, H1R signaling involves calcium-dependent phospholipase stimulation and generation of IP3, while H2R signaling involves adenylate cyclase stimulation and cAMP formation.

The receptor binding study of human peripheral blood lymphocytes has suggested that histamine trifluoromethyltoludine (HTMT) derivative lead to a two-phase enhancement in intracellular calcium $\left(\mathrm{Ca}^{2+}\right)$ and an increase in inositol phosphate (IP3) production. The increase in calcium $\left(\mathrm{Ca}^{2+}\right)$ was thoroughly antagonized through high concentrations of histamine but not by the classical histamine H1-, H2- or H3- receptor antagonists [332]. These observations demonstrate that HTMT have a specific binding site on lymphocytes, which is different for three classic histamine receptors. Several functional studies demonstrated that histamine primarily modulates $\mathrm{T}$-suppressor activity including delayed type hypersensitivity (DTH), cytotoxic Tlymphocyte-mediated target cell killing, cell-mediated lympholysis, and natural killer activity by H2R signaling [333]. Although, some studies suggest that activation of the H2Rs indirectly increases the allergic cascade. Suppressor T-cells were found to be more responsive to histamine than $\mathrm{T}$ helper cells or cytotoxic T cells [334]. Likewise, the response to histamine in $\mathrm{T}$ helper cells and cytotoxic T-cells was highly enhanced after mitogenic stimulation [334]. It is more important to note that in humans, histamine suppresses the pro- liferation of mixed T lymphocytes via H2R [335, 336]. Further, it had been confirmed that histamine inhibited lipopolysaccharide (LPS)-stimulated IFN- $\gamma$-gene expression from human peripheral blood mononuclear cells (PBMC) [337]. IFN- $\gamma$ cytokine releases human CD4+T-cell clones, which are classified as either Th0, Th1 or Th2 based on their cytokines (IL-4 and IFN- $\gamma$ ) secretion patterns [338]. Notably, histamine-induced inhibition of IFN- $\gamma$ secretion was seen in Th1 clones but not Th2 clones and the effect was reversed by $\mathrm{H} 2 \mathrm{R}$ and not $\mathrm{H} 1-$ or $\mathrm{H} 3$-receptor antagonists. Histamine has been demonstrated to directly enhance the synthesis of the proinflammatory cytokines (IL-1b and IL-6) through lymphocytes, anti-CD23- and anti-CD28-stimulated release of IL-4 and IL-5 (but not IL-2) or IFN from T lymphocytes can be inhibited by terfenadine treatment [320]. Similarly, several other studies have suggested that histamine leads to synthesis and release of a lymphocyte chemo-attractant factor (LCF) from H2R bearing lymphocytes and also results in release of two different types of lymphocyte migration inhibitory factors (LyMIFs) from only a subset of H2R bearing lymphocytes [339, 340].

\section{Neutrophils}

Neutrophils have been demonstrated to express H1R and H2R [341, 342], and it had been suggested that the impacts of histamine on neutrophils are inhibitory via $\mathrm{H} 2 \mathrm{R}$. In vitro studies showed the autologous serum-sensitized chemotaxis of neutrophils both in normal, atopic subjects which is abolished by histamine in a dose-dependent manner, and this inhibition was more effective in atopic individuals [343]. It 
is more important to note that incubation of neutrophils from these individuals with cimetidine, but not promethazine, causes reversal of the histamine-sensitized inhibition of neutrophil chemotaxis. In vivo study has demonstrated that the histamine administration by either infusion and subcutaneous injection or inhalation diminished neutrophil chemotaxis in healthy volunteers [344]. Several studies have suggested that histamine inhibits the activation of neutrophils as demonstrated by inhibition of fMet-Leu-Phe induced superoxide $\left(\mathrm{O}^{2-}\right)$ formation, degranulation and membrane potential changes acting by H2R signaling [345, 346].

\section{Monocytes, Macrophases and Dendritic Cells}

The presence of histamine receptors (H1R and H2R) on human monocytes and macrophages [347, 348] indicates that in allergic disease histamine also modulate the activity of these cells. Differentiation of monocytes into macrophages causes switching over from H2R to H1R [347]. Several other recent studies have suggested (investigations which were performed with exogenously added histamine) that it has a potential role in modulating maturation and function of monocytes, and dendritic cells. Activated monocytes and dendritic cells have a significant potential role in release of histamine, which acts in autocrine and paracrine fashion and modifies dendritic cell markers. Histamine was found to inhibit the production of TNF- $\alpha$ and IL-12, and to augment the production of IL-10 in response to Toll-like receptor ligands by acting on the H2R, in human monocytes [24, 89, 349, 350 ], while, in human monocyte-derived dendritic cells similar inhibition of IL-12 and enhancement of IL-10 production was investigated. Recently, H4R involvement in suppression of IL-12 was observed [351]. In the P. acnes-primed and LPS-stimulated hepatitis model, endogenous histamine production via macrophages and Kupffer cells was reported to play a protective role through acting on the H2R [352]. This study was performed with attention to endogenous histamine synthesis in macrophages and Kupffer cells. Furthermore, it has been documented that dendritic cells (DC) are especially antigen-presenting cells, which mature from monocytic and lymphoid precursors and leads to acquisition of dendritic cell (DC) 1 and DC2 phenotypes that drives the development of Th1 and Th2 cells, respectively. Histamine potentially participates in functions and activity of DC precursors as well as their immature and mature forms. It is important to note that immature and mature dendritic cells (DCs) express all four histamine receptors [270, 353, 354] see in Fig. (11) for more details. Furthermore, in the differentiation process of DC1 from monocytes, H1R and H3R act as positive stimulants that enhance antigen-presentation capacity and proinflammatory cytokine production and also Th1 priming activity. $\mathrm{H} 2 \mathrm{R}$ acts as a suppressive molecule and enhances IL-10 production, and stimulates IL-10 producing T-lymphocytes (Th2 cells) for antigen-presentation [355]. The suppressive impact of histamine by H2R seems through the regulation of ICAM1 and B7.1 expression facilitating the reduction of innate immune responses activated by LPS [356]. Indeed, histamine stimulates intracellular $\mathrm{Ca}^{2+}$ flux, chemotaxis, and actin polymerization in immature dendritic cells due to activation of H1R and H3R subtypes. Notably, in maturation of dendritic cells (DCs) results in loss of these responses. However, histamine dose dependently augments intracellular cAMP levels and stimulates IL-10 secretion in maturing dendritic cells, while inhibiting production of IL-12 through H2R [355]. Human monocyte-derived dendritic cells express both histamine receptors (H1R and H2R) and can stimulate CD86 expression via histamine, while human epidermal Langerhans cells express neither H1R nor H2R due to effect of transforming growth factor (TGF)- $\beta$ [357].

\section{E. Eosinophils}

Eosinophils express both histamine $\mathrm{H} 1$ - and H2receptors. The effect of histamine on eosinophils is stimulatory at lower concentrations. It had been suggested that preincubation of eosinophils with $10^{-5} \mathrm{M}$ or higher concentrations of histamine suppressed the chemotactic response of eosinophils to endotoxin-activated serum (C5a) while preincubation of eosinophils with a lower concentration of $10^{-6} \mathrm{M}$ histamine had the inverse effect, enhancing the C5aactivated eosinophil chemotaxis. Furthermore, H2R- and H1R-antagonists, respectively, inhibited these impacts. The expression of a novel H3R mediates the direct eosinophil chemotactic response towards histamine [358]. It has also been observed that this receptor seems to have similar antagonist binding activities to those reported for the H3R observed in the CNS, although it does not bind R- $\alpha-$ methylhistamine or $\mathrm{N}-\alpha$-methylhistamine with similar potency as histamine suggesting differences between the activities and function of H3Rs expressed in CNS and on the eosinophil. Histamine acting via the H1R also augments eosinophil $\mathrm{C} 3 \mathrm{~b}$ receptor expression [359], and it was considered as an important mechanism that was found to be involved in the amplification of complement-dependent parasite killing. However, 0.1-50 mM histamine was demonstrated to block eosinophil degranulation, as shown by diminished release of C5a-mediated eosinophil peroxidase [360]. It has been suggested that selective H2R agonists produced an impact similar to that shown by histamine and that cimetidine (H2Rantagonist) reversed this inhibitory impact of histamine. Furthermore, in contrast, treatment with neither mepyramine (H1R-antagonist) nor thioperamide (H3R-antagonist) significantly inhibited the C5a-induced release of eosinophil peroxidase from eosinophils suggesting the significant role of H2R in same respect. An important relation between histamine and eosinophil in allergic disease has been documented in vivo in patients with allergic rhinitis undergoing segmental allergen challenge, and followed by airway sampling via bronchoalveolar lavage (BAL) after $5 \mathrm{~min}$ and $48 \mathrm{~h}$ [361]. While, in response to in vitro antigen challenge, maximal blood histamine release was determined in each patient before segmental bronchoprovocation. The number of eosinophils in BAL samples collected after $48 \mathrm{~h}$ were significantly enhanced and correlated with the maximal basophil histamine release noted for each individual suggesting a direct causal relationship between basophilic mediator release and airway eosinophilia.

\section{F. Epithelial Cells}

The implications of histamine have been observed in cultured human bronchial epithelial cells that demonstrate functionally active $\mathrm{H} 1 \mathrm{R}$ and $\mathrm{H} 2 \mathrm{R}$ as demonstrated by histamine-induced generation of cGMP for H1R and cAMP for $\mathrm{H} 2 \mathrm{R}$ and blockage of cGMP release by treatment with pyrilamine and cAMP release by treatment with titotidine [362]. Recently, the expression of H1-receptor on cultured human 
ocular and nasal epithelial cells indicates that histamine may potently influence the property of these cells $[363,364]$. It has been demonstrated that nasal and bronchial epithelial cells synthesizes and release distinct biologically active mediators including cell adhesion molecules, endothelin, cytokines, arachidonic acid metabolites, major histocompatibility complex class (MHC) II antigens, neuropeptide degrading enzymes and nitric oxide that influence the migration, activation and also function of both structural and inflammatory cells involved in the pathophysiology of allergic rhinitis and asthma [365, 366]. Notably, the implications of histamine on mediator release from human bronchial epithelial cells demonstrated that H1R modulation with $2 \mathrm{mM}$ histamine led to induction of cytoplasmic phospholipase A2 mRNA, activation of the transcription factor NF-k $\beta$, production of leukotriene $\mathrm{B} 4$, and expression of IL-8 [367]. It has been shown that histamine-induced enhancement in leukotriene B4 was inhibited by incubation of the cells with specific 5lipoxygenase activating protein inhibitors and Zileuton and expression of IL-8 was blocked by diphenhydramine, and 5lipoxygenase activating protein inhibitors and Zileuton indicating an important network of histamine-modulated inflammatory mechanisms within the airways. Similarly, histamine induced the release of IL-6, IL-8 and GM-CSF from human corneal and conjunctival epithelial cells in a dosedependent manner at physiologically or pathologically relevant concentrations and several H1R-antagonists, but not H2R-antagonist (ranitidine) or H3R-antagonist (thioperamide) blocked this cytokine release [368]. Indeed, the role of epithelial cells as modulators of inflammation, mainly in allergic diseases has been an important subject of much discussion for future prospects.

\section{G. Endothelial Cells}

The contribution of endothelial cells to the pathophysiology of allergic disorder has mainly been investigated. The significant effect of histamine on vascular permeability has well been demonstrated and is a consequence of H1R signaling that results in the contraction of F-actin fibres of the endothelial cytoskeleton and formation of gaps in the post capillary venules and extravasation of macromolecules [369]. The functionally potent H1R and/or H2R is expressed on human endothelial cells present in distinct tissues (the airway mucosa, eye, skin, brain and umbilical vein) [370]. Human umbilical vein endothelial cells have been the most investigated in mechanistic studies, because of comparatively easier and greater access to these cells. Currently, in a recent study it has been suggested that histamine itself regulates the expression of histamine receptor (HR) subtypes on endothelial cells and influences the overall significant role in inflammatory response in allergic disease [371]. It has been documented that the levels of mRNA for both the receptors (H1R and $\mathrm{H} 2 \mathrm{R}$ ) were down regulated by histamine, of which the effect on H2R-mRNA was rapid and long lasting, compared with a less pronounced, transient and shorter lasting impact on the H1R-mRNA. Furthermore, the H2R-mRNA was exclusively down regulated as a result of H1R protein activation. Histamine-induced receptor signaling on the endothelial cells directly modulates inflammatory changes in these cells. Therefore, treatment of human umbilical vein endothelial cell cultures with $10^{-4} \mathrm{M}$ or $10^{-5} \mathrm{M}$ histamine resulted in the release of lipophilic neutrophil chemoattractant activity from endothelial cells, an effect inhibited by cimetidine but not by diphenhydramine [372]. Histamine or H1R- or H2R-agonist stimulated adhesion of neutrophils to endothelial cells, participated in activation of phospholipase $\mathrm{C}$, guanylate cyclase and nitric oxide synthase isozymes, since inhibition of these enzymes with specific inhibitors decreases this adhesion [372]. The impact of histamine was found to be mediated by both $\mathrm{H} 1$-receptor and $\mathrm{H} 2$-receptor signaling and modulation of P-selectin on endothelial cells in the mesentery. Thus, histamine receptors are involved in significant implications in the field of histamine research in endothelial cells.

\section{IMPLICATION OF HISTAMINE ON CYTOKI- NES PRODUCTION}

It has been documented that histamine stimulates cytokine synthesis in allergic inflammation via two main different mechanisms:

(a) Direct effects of histamine on cytokine synthesis and

(b) Modulation of cytokine production stimulated by immunologic stimuli.

Histamine differentially modulates IL- 4 and IFN- $\gamma$ release from T cells [338], inhibits TNF- $\alpha$ [373] and IL-12 synthesis via human monocytes [374] while it directly modulates IL-10 [330] and IL-18 production from human monocytes [375]. In addition, it inhibits IFN- $\gamma$, TNF- $\alpha$, and IL-12 and enhances IL-10 synthesis in LPS- or mitogen-activated, peripheral blood mononuclear cells $[374,376]$, and increases IL-1 stimulated synthesis of IL-6 by monocytes [377]. These complex impacts of histamine were found to be mediated through the activation of H1R [378], H2R [374], and H3R on immune cell cytokine synthesis [330]. Recently, cloned H4R has been characterized as functionally active to modulate cytokines [274, 284, 285]. Several investigators have observed that low concentrations of histamine [i.e., found in the bronchoalveolar lavage (BAL) fluid of patients with bronchial asthma or at other sites of allergic inflammation] [352, 379], modulates human lung macrophages. The rationale for studying human lung macrophage was the high prevalence of macrophages in the human lung parenchyma and in the BAL fluid [380]. An important study has been done on macrophages, which were purified (approximately 98\%) from the lung parenchyma of thoracic surgery. Patients were incubated $(1$ to $18 \mathrm{~h})$ with low doses of histamine $\left(10^{-9}\right.$ to $10^{-7}$ $\mathrm{mol} / \mathrm{L}$ ) that was compared to those released in vivo in distinct pathophysiology. It has been observed that histamine stimulated the de novo synthesis of IL-6 from macrophages [304], and these impacts were reproduced via the H1R agonist (6-[2-(4-imidazolyl)ethylamino]-N-(4-trifluoromethylphenyl) heptane carboxamide) but not by the H2-receptor agonist (dimaprit) suggesting that those were H1R mediated events [304]. Thus, these results are in line with the general investigation that H1R modulation is related with intracellular $\mathrm{Ca}^{2+}$ influx and demonstrated that this signal transduction pathway is active in human macrophages [381]. The H1Rmediated activation of macrophages was documented by demonstrating that histamine-induced IL-6 release was blocked in a concentration-dependent fashion by enhancing concentrations of the selective H1R-antagonist (fexofenadine) [304]. While the H2R-antagonist (ranitidine) had no effect on IL-6 release or $\mathrm{Ca}^{2+}$ signal produced by histamine. A more valuable research in this field has provided the sig- 
nificant evidence that low concentrations of histamine promote exocytosis and IL-6 synthesis by inducing H1Rs and activating intracellular $\mathrm{Ca}^{2+}$ signaling in macrophages. This investigation enhances the intriguing possibility that, via activating macrophage functions, histamine might be implicated in the long-term control of inflammation.

\section{SIGNIFICANCE OF HISTAMINE IN AUTOIM- MUNITY AND IN ALLERGIC DISEASES}

It is highly significant in field of immunomodulation that endogenous levels of histamine influence the repertoire of autoantibodies. Histamine has been observed to influence several aspects of the immune response, including antibody production $[12,13,189]$. It has been characterized that the repertoire of natural autoantibodies in histidine decarboxylase (HDC) diminished mice [33] was unable to produce histamine. HDC-diminished and wild type mice differed in the patterns of reactivity of their immunoglobulin-M (IgM) and immunoglobulin-G (IgG) natural autoantibodies [382]. The natural autoantibodies in HDC diminished sera manifested a larger repertoire of $\operatorname{IgM}$ autoantibodies than did the wild type sera [382]. The self-antigens bound by IgM from HDC diminished mice includes structural proteins, enzymes related with cellular metabolism, double-stranded DNA and single stranded DNA, and tissue-specific antigens like insulin [382]. It was noted that relatively fewer differences in the natural autoantibodies repertoire of $\mathrm{IgG}$ autoantibodies of the mice, notably, the HDC diminished sera reacted with glutamic acid decarboxylase (GAD) [382], an antigen related with autoimmune diabetes [383]. It has been documented that GAD-specific antibodies in HDC diminished mice reflect an enhanced susceptibility to develop autoimmune diabetes. Therefore, this demonstrates that factors not directly associated to antigenic activation such as endogenous levels of histamine can influence the natural autoantibodies repertoire [382]. Thus, disorders of immune system characterized by altered levels of endogenous histamine, such as allergies, might be reflected as specific alterations in the repertoire of natural autoantibodies.

\section{A. Urticaria and Angioedema}

Urticaria is the medical word for itchy wheals or hives (pale red swellings of skin "wheals" that occur in groups on any part of the skin) and angioedema known as deep mucocutaneous swelling often occur together with urticaria. Urticaria is classified, based on its temporal evolution, as acute (less than 6 weeks) or chronic (more that 6 weeks). Acute urticaria is related with sensitivity to foods, latex, and certain drugs and is often immunoglobulin-E (IgE)-mediated. Chronic urticaria includes the physical urticarias and urticarial vasculitis but allergic causes of chronic urticaria were rarely identified. Some cases of chronic urticaria have been associated with circulating $\operatorname{IgG}$ autoantibodies against FceRI $\alpha$ [384] and autoantibodies against IgE [385]. The frequency of autoantibodies to FceRI $\alpha$ in chronic urticaria has been estimated 30-50\%. These autoantibodies to FceRI $\alpha$ found to be functional i.e. they can cause histamine release from basophils under in vitro condition, however, evidences increasingly suggests that such autoantibodies were also functional in vivo. Other evidences have suggested that the serum from many patients with chronic urticaria causes an immediate autologous wheal and flare response (i.e. a posi- tive autologous serum skin test) and many of such patients have evidence of circulating functional IgG autoantibodies to the high affinity $\operatorname{IgE}$ receptor (FceRI $\alpha$ ). The current mainstream thought is that in such patients the IgG autoantibodies causes the visible urticarial skin lesions. It has been documented that in chronic urticaria the autoantibodies causing histamine release were predominantly $\operatorname{IgG} 1$ and $\operatorname{IgG} 3$. Thus, the presence of these autoantibodies characterizes the socalled chronic autoimmune urticaria. A cause-and-effect relation between levels of autoantibodies, histaminereleasing factors, and the clinical manifestations of chronic urticaria has still a part of research. However, severe cases often suggest that autoantibodies or circulating histaminereleasing factors do have an important role [386]. Hereditary angioedema is a rare autosomal dominant disorder caused by the absence of the inhibitor of the first component of complement.

\section{B. Allergic Rhinitis}

Allergic rhinitis has been characterized by itching, sneezing, rhinorrhea, and nasal obstruction. Perennial allergic rhinitis can be distinguished from non-allergic, noninfectious forms of rhinitis [idiopathic (vasomotor) rhinitis, non-allergic rhinitis with eosinophilia syndrome, hormonal rhinitis, drug-stimulated rhinitis, and food-induced rhinitis]. The treatment of allergic diseases (allergic rhinitis) consists of allergen avoidance, anti allergic medication, and immunotherapy for specific allergens which is known as desensitization or hyposensitization. Recently, the drugs commonly used to treat allergic rhinitis are antihistamines (histamine antagonists) and anticholinergic agents for the relief of symptoms and corticosteroids to suppress allergic inflammation. H1R-antagonists (loratadine, cetirizine, and fexofenadine) are less sedating and more pharmacologically selective than earlier antihistamines. Some H1R-antagonists (cetirizine) block allergen-sensitized infiltration of tissue by eosinophils, an influence that may be independent of their impacts on H1R [387].

\section{Atopic Dermatitis}

Atopic dermatitis (AD) or atopic eczema is a chronic relapsing pruritic skin disease with a high incidence in the first year of life. AD can persist into childhood, symptoms usually remit by puberty. $\mathrm{AD}$ is characterized by two phases: $1^{\text {st }}$ phase with acute lesions predominated by Th2 cytokines (IL-4, IL-5 and IL-13), $2^{\text {nd }}$ phase that is associated with eczematous chronic atopic dermatitis lesions by Th1 cytokine (INF- $\gamma$ and IL-12). Atopic dermatitis can also be present in adults and affects more than $10 \%$ of the total population, with $80-90 \%$ of those affected being children under 5 years of age in Western population [388, 389]. Atopic dermatitis is often regarded as a cutaneous form of atopy; as a result, 50$80 \%$ of children with AD will develop asthma or allergic rhinitis by 5 years of age later in life and the high serous concentration of $\operatorname{IgE}$ [390]. This temporal progression of atopic symptoms from atopic dermatitis to allergic sensitization of the skin, food allergy, hay fever (allergic rhinitis) and later airway hyperresponsivness and airway inflammation or asthma, has been named the "allergic march" [391, 392].

In $\mathrm{AD}$, the skin becomes extremely itchy. Scratching leads to redness, swelling, cracking, "weeping" clear fluid, and finally crusting and scaling. It is frequently perceived as 
a minor dermatological disorder. However, the high prevalence of this condition carries financial and social cost not only for the community, regarding medical and hospital cost but also for the patient and the patient's family [393]. In AD, inflammation results from interactions of immune cells $[\mathrm{T}$ cells (Th1 and Th2), dendritic cells (langerhans dendritic cells and inflammatory dendritic epidermal cells), mast cells and eosinophils] and kerotinocytes. The complex picture of the AD lesion is aggravated by environmental and genetic factors that increase the difficulty of understanding the mechanisms behind this complex pathology [388].

\section{ROLE OF HISTAMINE IN MALIGNANCIES}

Malignant melanoma is a well known life-threatening tumor (with a high rate of metastasis and strong malignant potential). Recently, the immune response against melanoma was compromised through multiple escape mechanisms of the tumor, which have been uncovered partially via thorough immunological and molecular analyses. These analyses were documented by gene-expression profiling. It has been suggested that melanoma-derived histamine should be included as a significant factor participated in bi-directional interactions between the tumor tissue and infiltrating immune cells. Notably, the presence and activity of histamine has been demonstrated to be relevant by directly stimulating or suppressing growth of the melanoma (i.e. depending on the local histamine receptor balance) and indirectly shifting the local $\mathrm{T}$-cell polarization towards a predominance of Th2 cells [394].

\section{RELATION OF HISTAMINE-CYTOKINE DURING HEMATOPOIESIS}

Many researchers have reported that exogenous histamine promote the entry of colony-forming units-spleen (CFU-S) into cell cycle and showed that this mediator stimulated granulocyte precursors, when added during in vitro cultures $[395,396]$. Recently, it has been demonstrated that a similar positive effect on hematopoietic progenitors was induced by endogenous histamine. Histamine is synthesized in response to hematopoietic growth factors (IL-3, GM-CSF and IL-1) generated during the immune response. It was probably not needed for maintaining bone marrow homeostasis, but involved in inducible hematopoiesis, and satisfies the enhanced requirements of an efficient host defense. There were several reports in support of a positive effect of histamine on granulopoiesis, but side effects of some histamine receptor ligands have also been described. Rare cases of agranulocytosis have been observed in response to H2receptor antagonist (cimetidine) and H4R antagonist (clozapine). It should be confirmed and re-evaluated by several reports, as regards the significant role of various histamine receptors; those expressions are most abundant in bone marrow [14].

\section{FUTURE PROSPECTS}

Histamine receptors have been important drug targets for many years. Their physiological and pathological relevance and distribution in various tissues are being documented, while the exact role of histamine receptors in immunomodulation is still unclear. The previous studies have shown immunomodulatory role of $\mathrm{H} 1$ - and $\mathrm{H} 2$-receptors and their po- tent role on lymphocytes (T-cells and B-cells), but all these reports have studied the antibody concentrations at a single time period taking single blood samples from experimental animals $[105,188,189,397]$. Our recent findings in immunoregulatory processes, demonstrated that total antibody, total IgM and total IgG generation profile in pheniramine (H1R-antagonist)-treated group is completely suppressed as compared to ranitidine (H2R-antagonist)- treated and control group, while total antibody and total IgM in ranitidine (H2R antagonist)-treated group is suppressed initially and enhanced in a later phase in comparison to control group, and IgG profile remained suppressed in comparison to control group. Thus, our results demonstrate B-cell proliferation in response to anti-IgM is increased in H2R-antagonist treated rabbits and is diminished in H1R-antagonist treated rabbits, and that H1R-antagonist treated rabbits display diminished antibody production against a $\mathrm{T}$ cell-dependent antigenSRBC as compared with H2R-antagonist treated and control rabbits [398].

The scope of histamine research has been implicated in immune responses of both the Th1 and Th2 lymphocytes. The newly discovered H4-receptor plays an important role in inflammation and has opened a new way for the functions of histamine in inflammation, allergy and autoimmune diseases. The data on the role of H3- and H4-receptors in immune regulation are limited. Due to lack of immunomodulatory researches on $\mathrm{H} 3$ - and H4-receptors, we planned ongoing studies to find out immunomodulatory role via several specific antagonists and agonists.

The antagonists for H1- and H2-receptors have been introduced into market for a long time and it is assumed that within the next few years the H3- and H4-receptor antagonists will be freely available in market. As we planned our ongoing researches on role of histamine receptors in immunomodulation, Tocris Bioscience, Tocris Cookson Ltd. (United Kingdom) has donated highly potent and specific histaminergic product as quotation code: "Donation 24.08.07" including products HTMT dimaleate [6-[2-(4imidazolyl)ethylamino]-N-(4-trifluoromethylphenyl)heptanecarboxamide dimaleate], Amthamine dihydrobromide [2amino-5-(2-aminoethyl)-4-methylthiazole dihydrobromide], (R)-(-)- $\alpha$-methylhistamine dihydrobromide [(R)-(-)- $\alpha-$ methyl-1H-imidazole-4-ethanamine], Imetit dihydrobromide [5-[2-(imidazol-4-yl)ethyl]isothiourea dihydrobromide], Clobenpropit dihydrobromide [N-(4-Chlorobenzyl)-S-[3(4(5)-imidazolyl)propyl]isothio urea dihydrobromide], Iodophenpropit dihydrobromide [N-[2-(4-iodophenyl)ethyl]-S-[3(4(5)-imidazolyl)propyl]isothiourea dihydrobromide] (see chemical structures in Fig. (12)). In future, we are planning to conduct researches on immunomodulation by H4-receptor agonist (4-Methylhistamine dihydrochloride) and antagonist (JNJ 10191584 maleate).

Thus, the recent data on the novel functions of histamine receptors (H1-, H2-, H3- and H4) have opened an interesting new chapter in immune regulation and immunomodulation in the history of histamine research and should lead to deeper relevance, and understanding treatments of pathological processes those regulating several essential events in allergies and autoimmune diseases. 
<smiles>CC(CCCCC(=O)Nc1ccc(C(F)(F)F)cc1)NCCc1c[nH]cn1</smiles>

$.2 \mathrm{C}_{4} \mathrm{H}_{4} \mathrm{O}_{4}$

H1R-agonist (HTMT dimaleate)

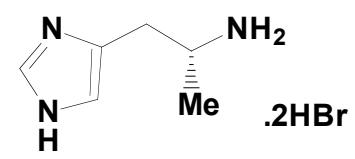

H3R-agonist ((R)-(-)- $\alpha$-Methylhistamine dihydrobromide)

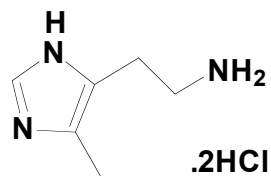

H4R-agonist (4-Methylhistamine dihydrochloride)

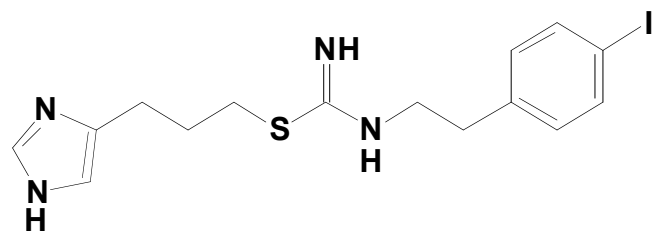

$.2 \mathrm{HBr}$

H3R-antagonist (Iodophenpropit dihydrobromide)<smiles>Cc1nc(N)sc1CCN</smiles>

H2R-agonist (Amthamine dihydrobromide)<smiles>N=C(N)SCCc1c[nH]cn1</smiles>

H3R \& H4R-agonist (Imetit dihydrobromide)

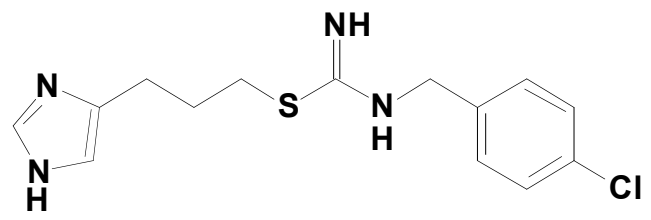

$.2 \mathrm{HBr}$

H3R-antagonist \& H4R-partial agonist (Clobenpropit dihydrobromide)

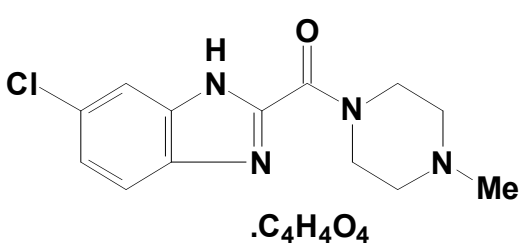

H4R-antagonist (JNJ 10191584)

Fig. (12). Histamine receptors agonists and antagonists kindly donated by Tocris Biosciences, Tocris Cookson Ltd., U.K.

\section{ACKNOWLEDGEMENTS}

M. Shahid is grateful to Department of Science \& Technology, Ministry of Science \& Technology, Government of India for awarding "Young Scientist Project Award" (FT/SR-L-111/2006) and Trivendra Tripathi acknowledges University Grants Commission [UGC letter DON F. 1933/2006 (CU) dated 01-02-2007], New Delhi, India for providing UGC Fellowship. The authors wish to thank Tocris Bioscience, Tocris Cookson Ltd. (United Kingdom) for kindly donating highly potent and specific histamine receptors-agonists as quotation code: "Donation 24.08.07".

\section{REFERENCES}

[1] MacGlashan D, Jr. Histamine: a mediator of inflammation. J Allergy Clin Immunol 2003; 112: S53-S9.

[2] Barger G, Dale HH. The presence in ergot and physiological activity of B-iminazoylethylamine. J Physiol Paris 1910; 40: 38-40.

[3] Best CH, Dale HH, Dudley HW, Thorpe WV. The nature of the vasodilator constituents of certain tissues. J Physiol Paris 1927; 62: 397-8.

[4] Dale HH. Some chemical factors in the control of the circulation: lecture 3. Lancet 1929; 1: 167-223.

[5] Steinhoff M, Griffiths C, Church M, Lugar TA. Histamine, in Rook's textbook of dermatology. In: Burns T, Breathnach S, Cox N, Griffiths C, Eds. Oxford (United Kingdom), Blackwell Science 2004; pp. 9.50-2.

[6] Riley JF, West GB. Histamine in tissue mast cells. J Physiol 1952; 117: 72-3.
[7] Ishizaka T, De Bernardo R, Tomioka H, Lichtenstein LM, Ishizaka $\mathrm{K}$. Identification of basophil granulocytes as a site of allergic histamine release. J Immunol 1972; 108: 1000-8.

[8] Parsons ME, Ganellin CR. Histamine and its receptors. Br J Pharmacol 2006; 147: S127-S35.

[9] Bouvet D, Staub AM. Action protectrice des ethers phenoliques au cours de l'intoxication histaminique. Comp Rend Soc Biol 1937; 124: 547-9.

[10] Halpern BN. Les anti histaminiques de synthese: essays de chimiothetapie des etats allergiques. Arch Int Pharmacodyn Ther 1942; 68: 339-408.

[11] IUPHAR Receptor database-Histamine receptor; [Assessed Feb 2008]. Available from: http: //www.iuphardb.org/GPCR/chapter Menu forward? chapter ID $=1287$

[12] Jutel M, Watanabe T, Akdis M, Blaser K, Akdis CA. Immune regulation by histamine. Curr Opin Immunol 2002; 14: 735-40.

[13] Schneider E, Rolli-Derkinderen M, Arock M, Dy M. Trends in histamine research: new functions during immune responses and hematopoiesis. Trends Immunol 2002; 23: 255-63.

[14] Dy M, Schneider E. Histamine-cytokine connection in immunity and hematopoiesis. Cytokine Growth Factor Rev 2004; 15: 393410.

[15] Higuchi M, Yanai K, Okamura N, et al. Histamine H (1) receptors in patients with Alzheimer's disease assessed by positron emission tomography. Neuroscience 2000; 1999: 721-9.

[16] Yokoyama $\mathrm{H}$. The role of central histaminergic neurin system as an anticonvulsive mechanism in developing brain. Brain Dev 2001; 23: 542-7.

[17] Haas H, Panula P. The role of histamine and the tuberomamillary nucleus in the nervous system. Nat Rev Neurosci 2003; 4: 121-30. 
[18] Fumagalli F, Baiardini I, Pasquali M, et al. Antihistamines: do they work? Further well-controlled trials involving larger samples are needed. Allergy 2004; 59: 74-7.

[19] Cooper DG, Young RC, Durant GJ, Ganellin CR. Histamine receptors, in comprehensive medicinal chemistry. In: Hansch C, Emmett JC, Eds. Oxford, Pergamon Press 1990; pp. 323-421.

[20] Akdis CA, Blaser K. Histamine in the immune regulation of allergic inflammation. J Allergy Clin Immunol 2003; 112: 15-22.

[21] Oda T, Morikawa N, Saito Y, Masuho Y, Matsumoto S. Molecular cloning and characterization of a novel type of histamine receptor preferentially expressed in leukocytes. J Biol Chem 2000; 275: 36781-6.

[22] Lovenberg TW, Roland BL, Wilson SJ, et al. Cloning and functional expression of the human histamine $\mathrm{H} 3$ receptor. Mol Pharmacol 1999; 55: 1101-7.

[23] Hill SJ, Ganellin CR, Timmerman H, et al. International Union of pharmacology. XIII. Classification of histamine receptors. Pharmacol Rev 1997; 49(3): 253-78.

[24] Szeberényi JB, Pállinger E, Zsinkó M, et al. Inhibition of effect of endogenously synthesized histamine disturbs in vitro human dendritic cell differentiation. Immunol Lett 2001; 76: 175-82.

[25] Ghosh AK, Hirasawa N, Ohtsu H, Watanabe T, Ohuchi K. Defective angiogenesis in the inflammatory granulation tissue in histidine decarboxylase-deficient mice but not in mast cell-deficient mice. J Exp Med 2002; 195: 973-82.

[26] Yokoyama M, Yokoyama A, Mori S, et al. Inducible histamine protects mice from P. acnes- primed and LPS- induced hepatitis through H2- receptor stimulation. Gastroenterology 2004; 127 : 892-902.

[27] Shiraishi M, Hirasawa N, Oikawa S, Kobayashi Y, Ohuchi K. Analysis of histamine-producing cells at the late phase of allergic inflammation in rats. Immunology 2000; 99: 600-6.

[28] Tanaka S, Deai K, Konomi A, et al. Expression of L-histidine decarboxylase in granules of elicited mouse polymorphonuclear leukocytes. Eur J Immunol 2004; 34: 1472-82.

[29] Taguchi Y, Tsuyama K, Watanabe T, Wada H, Kitamura Y. Increase in histidine decarboxylase activity in skin of genetically mast-cell deficient $\mathrm{W} / \mathrm{Wv}$ mice after application of Phorbol myristate 13-acetate: evidence for the presence of histamineproducing cells without basophilic granules. Proc Natl Acad Sci USA 1982; 79: 6837-41.

[30] Schneider E, Pollard H, Lepault F, Guy-Grand D, Minkowski M, Dy M. Histamine-producing cell-stimulating activity. Interleukin 3 and granulocyte-macrophage colony-stimulating factor induce de novo synthesis of histidine decarboxylase in hemopoietic progenitor cells. J Immunol 1987; 139: 3710-7.

[31] Yoshimoto T, Tsutsui H, Tominaga K, et al. IL-18, although antiallergic when administered with IL-12, stimulates IL-4 and histamine release by basophils. Proc Natl Acad Sci USA 1999; 96: 13962-6.

[32] Dy M, Lebel B, Kamoun P, Hamburger J. Histamine production during the anti-allograft response: demonstration of a new lymphokine enhancing histamine synthesis. J Exp Med 1981; 153: 293309

[33] Ohtsu H, Tanaka S, Terui $\mathrm{T}$, et al. Mice lacking histidine decarboxylase exhibit abnormal mast cells. FEBS Lett 2001; 502: 53-6.

[34] Kawakami T, Kitaura J. Mast cell survival and activation by IgE in the absence of antigen: a consideration of the biological mechanisms and relevance. J Immunol 2005; 175: 4167-73.

[35] Tanaka S, Takasu Y, Mikura S, Satoh N, Ichikawa A. Antigenindependent induction of histamine synthesis by immunoglobulin $\mathrm{E}$ in mouse bone marrow derived mast cells. J Exp Med 2002; 196: 229-35.

[36] Kohno M, Yamasaki S, Tybulewicz VL, Saito T. Rapid and large amount of autocrine IL-3 production is responsible for mast cell survival by IgE in the absence of antigen. Blood 2005; 105: 205965.

[37] Tanaka S, Mikura S, Hashimoto E, Sugimoto Y, Ichikawa A. $\mathrm{Ca}^{2+}$ influx- mediared histamine synthesis and IL-6 release in mast cells activated by monomeric IgE. Eur J Immunol 2005; 35: 460-8.

[38] Liu Y, Furuta K, Teshima R, et al. Critical role of PKC $\beta I$ In activation of mast cells by monomeric IgE. J Biol Chem 2005; 280: 38976-81.

[39] Tanaka S, Ichikawa A. Recent advances in molecular pharmacology of the histamine systems: immune regulatory roles of histamine produced by leukocytes. J Pharmacol Sci 2006; 101: 19-23.
[40] Yatsunami K, Ohtsu H, Tsuchikawa M, et al. Structure of the Lhidtidine decarboxylase gene. J Biol Chem 1994; 269: 1554-9.

[41] Nakagawa S, Okaya Y, Yatsunami K, et al. Identification of multiple regulatory elements of human L-Histidine decarboxylase gene. J Biochem 1997; 121: 935-40.

[42] Höcker M, Rosenberg I, Xavier R, et al. Oxidative stress activates the human histidine decarboxylase promoter in AGS gastric cancer cells. J Biol Chem 1998; 273: 23046-54.

[43] Raychowdhury R, Fleming JV, Mclaughlin JT, Bulitta CJ, Wang TC. Identification and characterization of a third gastrin response element (GAS-RE3) in the human histidine decarboxylase gene promoter. Biochem Biophys Res Commun 2002; 297: 1089-95.

[44] Watson F, Kiernan RS, Dimaline R. GATA proteins are potential negative regulators of HDC gene expression in the gastric epithelium. Biochem Biophys Acta 2002; 1576: 198-202.

[45] Kuramasu A, Saito H, Suzuki S, Watanabe T, Ohtsu H. Mast cell/basophil-specefic transcriptional regulation of human L-histidine decarboxylase gene by $\mathrm{CpG}$ methylation in the promoter region. $\mathrm{J}$ Biol Chem 1998; 273: 31607-14.

[46] Maeda K, Taniguchi H, Ohno I, et al. Induction of L-histidine decarboxylase in a human mast cell line, HMC-1. Exp Hematol 1998; 26: 325-31.

[47] Oh CK, Filler SE, Cho SH. Eukaryotic translation initiation factor 6 enhances histamine and IL-2 production in mast cells. J Immunol 2001; 166: 3606-11.

[48] Dy M, Pacilio M, Arnould A, et al. Modulation of histidine decarboxylase activity and cytokine synthesis in human leukemic cell lines: relationship with basophilic and/ or megakaryocytiv differentiation. Exp Hematol 1999; 27: 1295-305.

[49] Zhao CM, Chen D, Yamada H, et al. Rat stomach ECL cells: mode of activation of histidine decarboxylase. Regul Pept 2003; 114: 21 7.

[50] Rolli-Derkinderen M, Machavoine F, Baraban JM, Grolleau A, Beretta L, Dy M. ERK and p38 inhibit the expression of 4E-BP1 repressor of translation through induction of Egr-1. J Biol Chem 2003; 278: 18859-67.

[51] Fleming JV, Wang TC. The production of 53-55 $\mathrm{kDa}$ isoforms is not required for rat L-histidine decarboxylase activity. J Biol Chem 2003; 278: 686-94

[52] Fleming JV, Wang TC. Amino acid carboxy-terminal PEST domains mediate gastrin stabilization of rat L- histidine decarboxylase isoforms. Mol Cell Biol 2000; 20: 4932-47.

[53] Colucci R, Fleming JV, Xavier R, Wang TC. L-Histidine decarboxylase decreases its own transcription through down regulation of ERK activity. Am J Physiol 2001; 281: G1081-G91.

[54] Masahito O, Kohei Y, Yoh-Ichi S, et al. Recent advances in molecular pharmacology of the histamine system: organic cation transporter as a histamine tranporter and histamine metabolism. J Pharmacol Sci 2006; 101: 24-30.

[55] Maintz L, Novak N. Histamine and histamine intolerance. Am J Clin Nutr 2007; 85: 1185-93.

[56] Sekizawa $\mathrm{K}$, Nakazawa $\mathrm{H}$, Ohrui $\mathrm{T}$, et al. Histamine $N$ methyltransferase modulates histamine and antigen-induced bronchoconstriction in guinea pigs in vivo. Am Rev Respir Dis 1993; 147: 92-6.

[57] Barnes PJ, Cuss FM, Palmer JB. The effect of airway epithelium on smooth muscle contractility in bovine trachea. Br J Pharmacol 1985; 86: 685-91.

[58] Flavahan NA, Aarhus LL, Rimele TJ, Vanhoutte PM. Respiratory epithelium inhibits bronchial smooth muscle tone. J Appl Physiol 1985; 58: 834-8.

[59] Knight DA, Adcock JA, Phillips MJ, Thompson PJ. The effect of epithelium removal on human bronchial smooth muscle responsiveness to acetylcholine and histamine. Pulm Pharmacol 1990; 3: 198-202.

[60] Nakazawa H, Sekizawa K, Morkkawa M, et al. Viral respiratory infection causes airway hyperresponsiveness and decreases histamine $N$-methyltransferase activity in guinea pigs. Am J Respir Crit Care Med 1994; 149: 1180-5.

[61] Ash ASF, Schild HO. Receptors mediating some actions of histamine. Br J Pharmacol 1966; 27: 427-39.

[62] Hill SJ, Young JM, Marrian DM. Specific binding of 3Hmepyramine to histamine $\mathrm{H} 1$-receptors in intestinal smooth muscle. Nature (Lond.) 1977; 270: 361-3.

[63] Leurs R, Smit MJ, Timmerman H. Molecular pharmacological aspects of histamine receptors. Pharmacol Ther 1995; 66: 413-63. 
[64] Smit MJ, Hoffmann M, Timmerman H, Leurs R. Molecular properties and signaling pathways of the histamine H1 receptor. Clin Exp Allergy 1999; 29: 19-28.

[65] Togias A. H1-receptors: localization and role in airway physiology and in immune functions. J Allergy Clin Immunol 2003; 112: S60S8.

[66] Chang RSL, Tran VT, Snyder SH. Characteristics of histamine H1receptors in peripheral tissues labelled with $3 \mathrm{H}$-mepyramine. J Pharmacol Exp Ther 1979, 209: 437-42.

[67] Hill SJ, Young JM. Histamine H1-receptors in the brain of the guinea-pig and the rat: differences in ligand binding properties and regional distribution. Br J Pharmacol 1980; 68: 687-96.

[68] Arias-Montano JA, Young JM. Characteristics of histamine H1receptors on HeLa cells. Eur J Pharmacol Mol Pharmacol Sect 1993; 245: 291-5.

[69] Dickenson JM, Hill SJ. Characteristics of 3H-mepyramine binding in DDT1 MF2 cells: evidence for high binding to a functional histamine H1 receptor. Eur J Pharmacol Mol Pharmacol Sect 1994; 268: $257-62$

[70] Leurs R, Smit MJ, Meeder R, Ter Laak AM, Timmerman H. Lysine200 located in the fifth transmembrane domain of the histamine H1-receptor interacts with histamine but not with all H1 agonists. Biochem Biophys Res Commun 1995; 214: 110-7.

[71] Fukui H, Mizuguchi H, Lui YQ, et al. Purification of $3 \mathrm{H}-$ mepyramine receptor from rat liver and its amino acid sequence homology with debrisoquine-4-hydroxylase cytochrome P-450. Eur J Pharmacol 1990; 183: 1727-38.

[72] Liu Y, Furuta K, Teshima R, et al. Re-examination of $3 \mathrm{H}-$ mepyramine binding assay for histamine H1-receptor using quinine. Biochem Biophys Res Commun 1992; 189: 378-84.

[73] Dickenson JM, Hill SJ. Histamine H1-receptor-mediated calcium influx in DDT1 MF-2 cells. Biochem J 1992; 284: 425-31.

[74] White TE, Dickenson JM, Hill SJ. Histamine H1-receptormediated inositol phospholipid hydrolysis in DDT1 MF2 cells: agonist and antagonist properties. Br J Pharmacol 1993; 108: 196-203.

[75] Peroutka SJ, Snyder SH. 3H-Mianserin: differential labelling of serotonin2 and histamine1 receptors in rat brain. J Pharmacol Exp Ther 1981; 216: 142-8.

[76] Kamba S, Richelson E. Histamine H1-receptors in human brain labeled with [3H] doxepin. Brain Res 1984; 304: 1-7

[77] Taylor JE, Richelson E. High-affinity binding of [3H]doxepin to histamine H1-receptors in rat brain: possible identification of a subclass of histamine H1-receptors. Eur J Pharmacol 1982; 78: 279-85.

[78] Bouthenet ML, Ruat M, Salẻs N, Schwartz JC. A detailed mapping of histamine $\mathrm{H1}$-receptors in guinea pig central nervous system established by autoradiography with [125i]iodobolpyramine. Neuroscience 1988; 26: 553-600.

[79] Ruat M, Korner M, Garbarg M, et al. Characterization of histamine H1-receptor binding peptides in guinea-pig brain using [125i]iodoazidophenpyramine, an irreversible specific photoaffinity probe. Proc Natl Acad Sci USA 1988; 85: 2743-7.

[80] Treherne JM, Young JM. Digitonin-solubilised histamine H1receptors bind to polyethylenimine-treated glass-fibre filters. J Pharm Pharmacol 1988; 40: 730-3.

[81] Körner M, Bouthenet ML, Ganellin CR, et al. [125i]Iodobolpyramine, a highly selective probe for histamine H1-receptors in guinea pig brain. Eur J Pharmacol 1986; 120: 151-60.

[82] Palacios JM, Wamsley JK, Kuhar MJ. The distribution of histamine H1-receptors in the rat brain: an autoradiographic study. Neuroscience 1981; 6: 15-37.

[83] Palacios JM, Wamsley JK, Kuhar MJ. GABA benzodiazepine and histamine H1-receptors in the guinea pig cerebellum: effects of kainic acid injections studied by autoradiographic methods. Brain Res 1981; 214: 155-62.

[84] Villemagne VL, Dannals RF, Sánchez-Roa PM, et al. Imaging histamine $\mathrm{H} 1$ receptors in the living human brain with carbon-11pyrilamine. J Nucl Med 1991; 32: 308-11.

[85] Yanai K, Ryu JH, Watanabe T, et al. Histamine H1-receptor occupancy in human brains after single oral doses of histamine $\mathrm{H} 1$ antagonists measured by positron emission tomography. Br J Pharmacol 1995; 116: 1649-55.

[86] Barger G, Dale HH. Chemical structure and sympathomimetic action of amines. J Physiol (Lond) 1910; 41: 19-59.

[87] Dale HH, Laidlaw PP. The physiological action of bimidazolylethylamine. J Physiol (Lond) 1910; 41: 318-44.
[88] Black JW, Duncan WAM, Durant CJ, Ganellin CR, Parsons EM. Definition and antagonism of histamine H2-receptors. Nature (Lond) 1972; 236: 385-90.

[89] Hill SJ. Distribution, properties and functional characteristics of three classes of histamine receptor. Pharmacol Rev 1990; 42: 4583.

[90] Bolton TB, Clark JP, Kitamura K, Lang RJ. Evidence that histamine and carbachol may open the same ion channels in longitudinal smooth muscle of guinea-pig ileum. J Physiol (Lond) 1981; 320: 363-79.

[91] Bolton TB, Lim SP. Properties of calcium stores and transient outward currents in single smooth muscle cells of rabbit intestine. J Physiol (Lond) 1989; 409: 385-401.

[92] Donaldson J, Hill SJ. Histamine-induced hydrolysis of polyphosphoinositides in guinea-pig ileum and brain. Eur J Pharmacol 1986; 124: $255-65$

[93] Matsumoto J, Kanaide H, Nishimura J, Shogakiuchi Y, Kobayashi S, Nakamura M. Histamine activates H1-receptors to induce cytosolic free calcium transients in cultured vascular smooth muscle cells from rat aorta. Biochem Biophys Res Commun 1986; 135: $172-77$

[94] Kotlikoff MI, Murray RK, Reynolds EE. Histamine-induced calcium release and phorbol antagonism in cultured airway smooth muscle cells. Am J Physiol 1987; 253: C561-C6.

[95] Hall IP, Hill SJ. b2-adrenoceptor stimulation inhibits histaminestimulated inositol phospholipid hydrolysis in bovine tracheal smooth muscle. Br J Pharmacol 1988; 95: 1204-12.

[96] Panettieri RA, Murray RK, Depalo LR, Yadvish PA, Kotlikoff MI A human airway smooth muscle cell line that retains physiological responsiveness. Am J Physiol 1989; 256: C329-C35.

[97] Meyrick B, Brigham KI. Increased permeability associated with dilation of endothelial cell junctions caused by histamine in intimal explants from bovine pulmonary artery. Exp Lung Res 1983; 6: 1125.

[98] Svensjo E, Grega GJ. Evidence for endothelial cell-mediated regulation of macromolecular permeability by postcapillary venules. Fed Proc 1986; 45: 89-95.

[99] McIntyre TM, Zimmerman GA, Satoh K, Prescott SM. Cultured endothelial cells synthesize both platelet-activating factor and prostacyclin in response to histamine, bradykinin and adenosine triphosphate. J Clin Invest 1985; 76: 271-80.

[100] Carter TD, Hallam TJ, Cusack NJ, Pearson JD. Regulation of P2ypurinoceptor-mediated prostacyclin release from human endothelial cells by cytoplasmic calcium concentration. Br J Pharmacol 1988; 95: 1181-90.

[101] Hamilton KK, Sims PJ. Changes in cytosolic Ca21 associated with von Willebrand factor release in human endothelial cells exposed to histamine: study of microcarrier cell monolayers using the fluorescent probe indo-1. J Clin Invest 1987; 79: 600-8

[102] Van de Voorde J, Leusen I. Role of the endothelium in the vasodilator response of rat thoracic aorta to histamine. Eur J Pharmacol 1993; 87: 113-20.

[103] Villemain FM, Bach JF, Chatenoud LM. Characterization of histamine $\mathrm{H} 1$ binding sites on human $\mathrm{T}$ lymphocytes by means of 125Iiodobolpyramine. J Immunol 1990; 144: 1449-54.

[104] Kitamura Y, Arima T, Kitayama Y, Nomura Y. Regulation of [Ca21]i rise activated by doxepin-sensitive H1-histamine receptors in jurkat cells, cloned human T lymphocytes. Gen Pharmacol 1996; 27: 289-91.

[105] Bryce PJ, Mathias CB, Harrison KL, Watanabe T, Geha RS, Oettgen $\mathrm{HC}$. The $\mathrm{H} 1$ histamine receptor regulates allergic lung responses. J Clin Invest 2006; 116: 1624-32.

[106] Robinson RL. Histamine-induced catecholamine secretion from the cat adrenal medulla is mediated primarily by the H1-receptor. (Abstract) Fed Proc 1982; 41: 1060.

[107] Noble EP, Bommer M, Liebisch D, Herz A. H1-histaminergic activation of catecholamine release by chromaffin cells. Biochem Pharmacol 1988; 37: 221-8

[108] Livett BG, Marley PD. Effects of opioid peptides and morphine on histamine-induced catecholamine secretion from cultured, bovine adrenal chromaffin cells. Br J Pharmacol 1986; 89: 327-34.

[109] Bunn SJ, Sim ATR, Herd LM, Austin LM, Dunkling PR. Tyrosinehydroxylase phosphorylation in bovine adrenal chromaffin cells: the role of intracellular $\mathrm{Ca} 21$ in the histamine H1-receptorstimulated phosphorylation of Ser (8), Ser (19), Ser (31) and Ser (40). J Neurochem 1995; 64: 1370-8. 
[110] Bommer M, Liebisch D, Kley N, Herz A, Noble E. Histamine affects release and biosynthesis of opioid peptides primarily via H1-receptors in bovine chromaffin cells. J Neurochem 1987; 49: $1688-96$.

[111] Wan DCC, Marley PD, Livett BG. Histamine activates proenkephalin A mRNA but not phenylethanolamine-Nmethyltransferase mRNA expression in cultured bovine adrenal chromaffin cells. Eur J Pharmacol Mol Pharmacol Sect 1989; 172: 117-29.

[112] Guo ZG, Levi R, Graver LM, Robertson DA, Gay WA, Jr. Inotropic effects of histamine in human myocardium: differentiation between positive and negative components. J Cardiovasc Pharmacol 1984; 6: 1210-5.

[113] Genovese A, Gross SS, Sakuma I, Levi R. Adenosine promotes histamine H1-mediated negative chronotropic and inotropic effects on human atrial myocardium. J Pharmacol Exp Ther 1988; 247: 844-9.

[114] Hattori Y, Nakaya H, Tohse N, Kanno M. Effects of Ca21 channel antagonists and ryanodine on $\mathrm{H} 1$-receptor mediated electromechanical response to histamine in guinea-pig left atria. NaunynSchmiedeberg's Arch Pharmacol 1988; 337: 323-30.

[115] Hattori Y, Sakuma I, Kanno M. Differential effects of histamine mediated $\mathrm{H} 1$ - and $\mathrm{H} 2$-receptors on contractility, spontaneous rate and cyclic nucleotides in the rabbit heart. Eur J Pharmacol 1988; 153: 221-9.

[116] Schwartz JC, Arrang JM, Garbarg M, Ppllard H, Ruat M. Histaminergic transmission in the mammalian brain. Physiol Rev 1991; 71: 1-51.

[117] Yanai K, Ryu JH, Watanabe T, Iwata R, Ido T. Receptor autoradiography with $11 \mathrm{C}$ and [3H]-labelled ligands visualized by imaging plates. Neuroreport 1992; 3: 961-4.

[118] Ruat M, Schwartz JC. Photoaffinity labeling and electrophoretic identification of the H1-receptor: comparison of several brain regions and animal species. J Neurochem 1989; 53: 335-9.

[119] Traiffort E, Leurs R, Arrang JM, et al. Guinea-pig histamine H1receptor: I-gene cloning, characterization and tissue expression revealed by in situ hybridization. J Neurochem 1994; 62: 507-18.

[120] Haas HL. Histamine hyperpolarizes hippocampal neurones in vitro. Neurosci Lett 1981; 22: 75-8.

[121] Jahn K, Haas HL, Hatt H. Histamine activated currents in the olfactory bulb. Naunyn-Schmiedeberg's Arch Pharmacol 1995; 352: 386-93.

[122] Christian EP, Undem BJ, Weinreich D. Endogenous histamine excites neurones in the guinea pig superior cervical ganglion in vitro. J Physiol 1989; 409: 297-312.

[123] Khateb A, Serafin M, Muehlethaler M. Histamine excites pedunculopontine neurones in guinea pig brainstem slices. Neurosci Lett 1990; 112: 257-62.

[124] McCormick DA, Williamson A. Modulation of neuronal firing mode in cat and guinea pig LGNd by histamine: possible cellular mechanism of histaminergic control of arousal. J Neurosci 1991; 11:3188-99.

[125] Reiner PB, Kamondi A. Mechanism of antihistamine induced sedation in the human brain: H1-receptor activation reduces background leakage potassium current. Neuroscience 1994; 59: 579-88.

[126] Sharma A, Hamelin BA. Classic histamine H1 receptor antagonists: a critical review of their metabolic and pharmacokinetic fate from a bird's eye view. Curr Drug Metab 2003; 4: 105-29.

[127] Elz S, Kramer K, Pertz HH, et al. Histaprodifens: synthesis, pharmacological in vitro evaluation and molecular modeling of a new class of highly active and selective histamine (H1) receptor agonists. J Med Chem 2000; 43: 1071-84.

[128] Ma RZ, Gao J, Meeker ND, et al. Identification of Bphs, an autoimmune disease locus, as histamine receptor H1. Science 2002; 297: 620-3.

[129] Ruat M, Bouthenet ML, Schwartz JC, Ganellin CR. Histamine H1receptor in heart: unique electrophoretic mobility and autoradiographic localization. J Neurochem 1990; 55: 379-85.

[130] Yamashita M, Fukui H, Sugama K, et al. Expression cloning of a cDNA encoding the bovine histamine H1-receptor. Proc Natl Acad Sci USA 1991; 88: 11515-9.

[131] Ruat M, Traiffort E, Bouthenet ML, et al. Reversible and irreversible labeling and autoradiographic localization of the cerebral histamine $\mathrm{H} 2$ receptor using [125i]-iodinated probes. Proc Natl Acad Sci USA 1990; 87: 1658-62.
[132] Fujimoto K, Horio Y, Sugama K, Ito S, Liu YQ, Fukui H. Genomic cloning of the rat histamine $\mathrm{H} 1$ receptor. Biochem Biophys Res Commun 1993; 190: 294-301.

[133] Horio Y, Mori Y, Higuchi I, Fujimoto K, Ito S, Fukui H. Molecular cloning of the guinea-pig histamine H1-receptor gene. J Biochem 1993; 114: 408-14.

[134] Inove I, Taniuchi I, Kitamura D, et al. Characteristics of the mouse genomic histamine H1-receptor gene. Genomics 1996; 36: 178-81.

[135] De Backer MD, Gommeren W, Moereels H, et al. Genomic cloning, heterologous expression and pharmacological characterization of a human histamine H1-receptor. Biochem Biophys Res Commun 1993; 197: 1601-8.

[136] Smit MJ, Leurs R, Alevijnse AE, et al. Inverse agonism of histamine H2-antagonists accounts for up-regulation of spontaneously active histamine receptors. Proc Natl Acad Sci USA 1996; 93: 6802-7.

[137] Toll L, Snyder SH. Solubilization and characterization of histamine H1 receptors in brain. J Biol Chem 1982; 257: 13593-601.

[138] Treherne JM, Young JM. Temperature dependence of the kinetics of the binding of 3H-(1)-N-methyl-4-methyl diphenhydramine to the histamine H1-receptor: comparison with the kinetics of $3 \mathrm{H}-$ mepyramine. Br J Pharmacol 1988; 94: 811-22.

[139] Peakman MC, Hill SJ. Endogenous expression of histamine H1receptors functionally coupled to phosphoinositide hydrolysis in C6 glioma cells: regulation by cyclic AMP. Br J Pharmacol 1994; 113 : 1554-60.

[140] Birdsall NJM. Cloning and structure: function of the H2 histamine receptor. Trends Pharmacol Sci 1991; 12: 9-10.

[141] Timmerman H. Cloning of the H1 histamine receptor. Trends Pharmacol Sci 1992; 13: 6-7.

[142] Ohta K, Hayashi H, Mizuguchi H, Kagamiyama H, Fujimoto K, Fukui H. Site-directed mutagenesis of the histamine H1-receptor: roles of aspartic acid107, asparagine198 and threonine194. Biochem Biophys Res Commun 1994; 203: 1096-101.

[143] Moguilevsky N, Varsalona F, Guillaume JP, et al. Pharmacological and functional characterization of the wild-type and site-directed mutants of the human H1-histamine receptor stably expressed in CHO cells. J Recept Signal Transduction Res 1995; 15: 91-102.

[144] Leurs R, Smit MJ, Tensen CP, Ter Laak AM, Timmerman H. Sitedirected mutagenesis of the histamine $\mathrm{H} 1$-receptor reveals a selective interaction of asparagine 207 with subclasses of H1-receptor agonists. Biochem Biophys Res Commun 1994; 201: 295-301.

[145] Leurs R, Smit MJ, Timmerman H. Molecular pharmacological aspects of histamine receptors. Pharmacol Ther 1995; 66: 413-63.

[146] De Backer MD, Loonen I, Verhasselt P, Neefs JM, Luyten WHMML. Structure of the human histamine H1 receptor gene. Biochem J 1998; 335: 663-70.

[147] Bakker RA, Timmerman H, Leurs R. Histamine receptors: specific ligands, receptor biochemistry, and signal transduction. Clin Allergy Immunol 2002; 17: 27-64.

[148] Bakker RA, Schoonus SBJ, Smit MJ, Timmerman H, Leurs R. Histamine H1-receptor activation of nuclear factor-kB: roles for $\mathrm{G}$ gamma- and $\mathrm{G}$ alpha/11 subunits in constitutive and agonistmediated signaling. Mol Pharmacol 2001; 60: 1133-42.

[149] Hill SJ, Donaldson J. The H1-receptor and inositol phospholipids hydrolysis, in the histamine receptor. In: Schwartz JC, Haas HL, Eds. Wiley-Liss, New York 1992, pp. 109-128.

[150] Leurs R, Smit MJ, Menge WMBP, Timmerman H. Pharmacological characterization of the human histamine H2-receptor stably expressed in Chinese hamster ovary cells. Br J Pharmacol 1994; 112: 847-54.

[151] Megson AC, Dickenson JM, Townsend-Nicholson A, Hill SJ. Synergy between the inositol phosphate responses to transfected human adenosine A1-receptors and constitutive P2-purinoceptors in CHO-K1 cells. Br J Pharmacol 1995; 115: 1415-24.

[152] Claro E, Garcia A, Picacosta F. Histamine-stimulated phosphoinositide hydrolysis in developing rat brain. Mol Pharmacol 1987; 32: 384-90.

[153] Bailey SJ, Lippe IT, Holzer P. Effect of the tachykinin antagonist [D-Pro4, D-Trp7,9,10] substance P-(4-11) on tachykinin- and histamine-induced inositol phosphate generation in intestinal smooth muscle. Naunyn- Schmiedeberg's Arch Pharmacol 1987; 335: 296300 .

[154] Seifert R, Hagelüken A, Hoer A, et al. The H1- receptor agonist 2(3-chlorophenyl) histamine activates Gi proteins in HL-60 cells 
through a mechanism that is independent of known histamine receptor subtypes. Mol Pharmacol 1994; 45: 578-86.

[155] Schmidt HHHW, Zernikow B, Baeblich S, Bohme E. Basal and stimulated formation and release of L-arginine-derived nitrogen oxides from cultured endothelial cells. J Pharmacol Exp Ther 1990; 254: 591-97.

[156] Leurs R, Brozius MM, Jansen W, Bast A, Timmerman H. Histamine H1-receptor mediated cyclic GMP production in guinea-pig lung tissue is an L-arginine-dependent process. Biochem Pharmacol 1991; 42: 271-7.

[157] Yuan Y, Granger HJ, Zawieja DC, Defily DV, Chilian WM. Histamine increases venular permeability via a phospholipase C-NO synthase- guanylate cyclase cascade. Am J Physiol 1993; 264 : H1734-H9.

[158] Hattori Y, Nakaya H, Endou M, Kanno M. Inotropic, electrophysiological and biochemical responses in rabbit papillary muscles: evidence for co-existence of H1- and H2-receptors. J Pharmacol Exp Ther 1990; 253: 250-6.

[159] Muriyama T, Kajiyama Y, Nomura Y. Histamine-stimulated and GTP-binding protein-mediated phospholipase A2 activation in rabbit platelets. J Biol Chem 1990; 265: 4290-5.

[160] Donaldson J, Brown AM, Hill SJ. Temporal changes in the calcium dependence of the histamine H1-receptor-stimulation of the cyclic AMP accumulation in guinea-pig cerebral cortex. Br J Pharmacol 1989; 98: 1365-75.

[161] Garbarg M, Schwartz JC. Synergism between histamine H1- and $\mathrm{H} 2$-receptors in the cyclic AMP response in guinea-pig brain slices: effect of phorbol esters and calcium. Mol Pharmacol 1988; 33: 3843.

[162] Marley PD, Thompson KA, Jachno K, Johnston MJ. Histamineinduced increases in cyclic AMP levels in bovine adrenal medullary cells. Br J Pharmacol 1991; 104: 839-46.

[163] Sanderson EM, Iredale PA, Hill SJ. Role of Ca21 ions in the stimulation of cAMP accumulation by histamine in CHO-K1 cells transfected with the bovine H1-receptor. (Abstract) Br J Pharmacol 1996; $117: 7 \mathrm{P}$

[164] Del Valle J, Gantz I. Novel insights into histamine H2 receptor biology. Am J Physiol 1997; 273: 987-96.

[165] Gajtkowski GA, Norris DB, Rising TJ, Wood TP. Specific binding of $[3 \mathrm{H}]$-tiotidine to histamine H2-receptors in guinea pig cerebral cortex. Nature (Lond) 1983; 304: 65-7.

[166] Sterk GJ, Van Der Schaar MWG, Rademaker B, Timmerman H. Histamine H2-receptor binding on guinea-pig cerebral cortex. Agents Actions 1986; 18: 231-4.

[167] Gantz I, Munzert G, Tashiro T, Schäffer M, Wang L, Yamada T. Molecular cloning of the human histamine $\mathrm{H} 2$ receptor. Biochem Biophys Res Commun 1991; 178: 1386-92.

[168] Maayani S, Hough LB, Weinstein H, Green JP. Response of the histamine H2-receptor in the brain to antidepressant drugs, in Typical and Atypical Antidepressants: Molecular Mechanisms. In: Costa E, Racagni G, Eds. Raven Press, New York 1982; pp. 13367.

[169] Hirschfeld J, Buschauer A, Elz S, et al. Iodoaminopotentidine and related compounds: a new class of ligands with high affinity and selectivity for the histamine H2 receptor. J Med Chem 1992; 35 : 2231-8.

[170] Traiffort E, Pollard H, Moreau J, et al. Pharmacological characterization and autoradiographic localization of histamine H2-receptors in human brain identified with 125I-iodoaminopotentidine. J Neurochem 1992; 59: 290-99.

[171] Traiffort E, Ruat M, Arrang JM, Leurs R, Piomelli D, Schwartz JC. Expression of a cloned rat histamine $\mathrm{H} 2$ receptor mediating inhibition of arachidonate release and activation of cAMP accumulation. Proc Natl Acad Sci USA 1992; 89: 2649-53.

[172] Al-Gadi M, Hill SJ. Characterization of histamine receptors mediating the stimulation of cyclic AMP accumulation in rabbit cerebral cortical slices. Br J Pharmacol 1985; 85: 877-88.

[173] Al-Gadi M, Hill SJ. The role of calcium in the cyclic AMP response to histamine in rabbit cerebral cortical slices. Br J Pharmacol 1987; 91: 213-22.

[174] Johnson CL. Histamine receptors and cyclic nucleotides, in Pharmacology of Histamine Receptors. In: Ganellin R, Parsons M, Eds. Wright \& Bristol, England 1982; pp. 146-216.

[175] Black JW, Shankley NP. The isolated stomach preparation of the iuphar classification of histamine receptors 271 mouse: a physio- logical unit for pharmacological analysis. Br J Pharmacol 1985; 86: 571-79.

[176] Soll AH, Berglindh TPhysiology of isolated gastric glands and parietal cells: receptors and effectors regulating function, in physiology of the gastrointestinal tract. In: Johnson LR, Ed. Raven, New York 1987, pp. 883-909

[177] Hescheler J, Tang M, Jastorff B, Trauteein W. On the mechanism of histamine induced enhancement of the cardiac Ca21 current. Pflü gers Arch 1987; 410: 23-9.

[178] Levi RC, Alloatti G. Histamine modulates calcium current in guineapig ventricular myocytes. J Pharmacol Exp Ther 1988; 246: 377-83.

[179] Gross PM, Harper AM, Teasdale GM. Cerebral circulation and histamine: 1-participation of vascular $\mathrm{H} 1$ - and $\mathrm{H} 2$-receptors in vasodilatory responses to carotid arterial infusion. J Cereb Blood Flow Metab 1981; 1: 97-108.

[180] Eyre P, Chand N. Histamine receptor mechanism of the lung, in Pharmacology of Histamine Receptors. In: Ganellin CR, Parsons ME, Eds. Wright \& Bristol, England 1982; pp. 298-322.

[181] Edvinsson L, Gross PM, Mohamed A. Characterization of histamine receptors in cat cerebral arteries in vitro and in situ. J Pharmacol Exp Ther 1983; 225: 168-75.

[182] Foreman JC, Norris DB, Rising TJ, Webber SE. The binding of $3 \mathrm{H}$-tiotidine to homogenates of guinea-pig lung parenchyma. $\mathrm{Br} \mathrm{J}$ Pharmacol 1985; 86: 475-82.

[183] Ottosson A, Jansen I, Edvinsson L. Pharmacological characterization of histamine receptors in human temporal artery. Br $\mathrm{J}$ Clin Pharmacol 1989; 27: 139-45.

[184] Ting S, Dunsky EH, Zweiman B. Histamine suppression of eosinophilotaxis and histamine release in vivo. J Allergy Clin Immunol 1980; 65: 196-7.

[185] Plaut M, Lichtenstein LM. Histamine and immune responses, in The Pharmacology of Histamine Receptors. In: Ganellin CR, Parsons ME, Eds. Wright \& Bristol, England 1982; pp. 392-435.

[186] Melmon KL, Rocklin RE, Rosenkranz RP. Autacoids as modulators of the inflammatory and immune response. Am J Med 1981; 71: 100-6.

[187] Melmon KL, Khan MM. Histamine and its lymphocyte-selective derivatives as immune modulators. Trends Pharmacol Sci 1987; 8: 437-41.

[188] Banu Y, Watanabe T. Augmentation of antigen receptor-mediated responses by histamine H1 receptor signaling. J Exp Med 1999; 189: 673-82.

[189] Jutel M, Watanabe T, Klunker S, et al. Histamine regulates T-cell and antibody responses by differential expression of $\mathrm{H} 1$ and $\mathrm{H} 2$ receptors. Nature 2001; 413: 420-25.

[190] Gantz I, Schäffer M, Del Valle J, et al. Molecular cloning of a gene encoding the histamine $\mathrm{H} 2$ receptor. Proc Natl Acad Sci USA 1991; 88: 429-33.

[191] Ruat M, Traiffort E, Arrang JM, Leurs R, Schwartz JC. Cloning and tissue expression of a rat histamine $\mathrm{H} 2$-receptor gene. Biochem Biophys Res Commun 1991; 179: 1470-8.

[192] Traiffort E, Vizuete ML, Tadivellacombe J, Souile E, Schwartz JC, Ruat $\mathrm{M}$. The guinea-pig histamine $\mathrm{H} 2$ receptor-gene cloning, tissue expression and chromosomal localization of its human counterpart. Biochem Biophys Res Commun 1995; 211: 570-7.

[193] Fukushima Y, Oka Y, Saitoh T, et al. Structural and functional analysis of the canine histamine H2-receptor by site-directed mutagenesis: N-glycosylation is not vital for its action. Biochem $\mathrm{J}$ 1995; 310: 553-8.

[194] Kobayashi T, Inove I, Jenkins NA, Gilbert DJ, Copeland NG, Watanabe T. Cloning, RNA expression and chromosomal location of a mouse histamine H2-receptor gene. Genomics 1996; 37: 3904.

[195] Gantz I, Delvalle J, Wang LD, et al. Molecular basis for the interaction of histamine with the histamine-H2 receptor. J Biol Chem 1992; 267: 20840-3.

[196] Delvalle J, Gantz I, Wang LD, et al. Construction of a novel bifunctional biogenic amine receptor via 2 point mutations of the $\mathrm{H} 2$ histamine receptor. Mol Med 1995; 1: 280-6.

[197] Batzri S, Harmon JW, Thompson WF. Interaction of histamine with gastric mucosal cells: effect of histamine $\mathrm{H} 2$-antagonists on binding and biological response. Mol Pharmacol 1982; 22: 41-7.

[198] Gespach C, Abita JP. Human polymorphonuclear neutrophils. Pharmacological characterisation of histamine receptors mediating the elevation of cyclic AMP. Mol Pharmacol 1982; 21: 78-85. 
[199] Keller MB, Grund VR, Johnson CL. Impromidine stimulated adenylate cyclase activity in canine fat cell ghosts. (Abstract) Pharmacologist 1981; 23: 186.

[200] Leurs R, Traiffort E, Arrang JM, Tardird-Lacombe J, Ruat M, Schwartz JC. Guinea-pig histamine H1 receptor: II-stable expression in Chinese hamster ovary cells reveals the interaction with three major signal transduction pathways. J Neurochem 1994; 62: 519-27.

[201] Newton MV, Hough LB, Azimitia EC. Histamine-sensitive adenylate cyclase in monkey brain. Brain Res 1982; 239: 639-43.

[202] Olianas M, Oliver AP, Neff NH. Correlation between histamineinduced neuronal excitability and activation of adenylate cyclase in guinea pig hippocampus. Neuropharmacology 1984; 23: 1071-4.

[203] Kitbunnadaj R. Histamine receptors and their ligands. Naresuan Univ J 2005; 13: 41-53.

[204] Green JP. Histamine receptors in brain. Handb Psychopharmacol 1983; 17: 385-420.

[205] Kamba S, Richelson E. Antidepressants are weak competitive antagonists of histamine H2-receptors in dissociated brain tissue. Eur J Pharmacol 1983; 94: 313-8.

[206] Traiffort E, Ruat M, Schwartz JC. Interactions of mianserin, amitriptyline and haloperidol with guinea-pig cerebral histamine H2-receptors studied with 125I-iodoamino-potentidine. Eur J Pharmacol Mol Pharmacol Sect 1991; 207: 143-8.

[207] Chew CS, Petropoulos AC. Thapsigargin potentiates histaminestimulated $\mathrm{HCl}$ secretion in gastric parietal cells but does not mimic cholinergic responses. Cell Regul 1991; 2: 27-39.

[208] Delvalle J, Tsunoda Y, Williams JA, Yamada T. Regulation of [Ca21]i by secretagogue stimulation of canine gastric parietal cells. Am J Physiol 1992; 262: G420-G6.

[209] Seifert R, Hoer A, Schwaner I, Buschauer A. Histamine increases cytosolic Ca21 in HL-60 promyelocytes predominantly via $\mathrm{H} 2$ receptors with an unique agonist/antagonist profile and induces functional differentiation. Mol Pharmacol 1992; 42: 235-41.

[210] Delvalle J, Wang L, Gantz I, Yamada T. Characterization of H2 histamine receptor: linkage to both adenylate cyclase and $\left[\mathrm{Ca}^{2+}\right]$ signaling systems. Am J Physiol 1992; 263: G967-G72.

[211] Negulescu PA, Machen TE. Intracellular Ca regulation during secretagogue stimulation of the parietal cell. Am J Physiol 1988; 254: C130-C40.

[212] Dimitriadou V, Rouleau A, Dam Trung Tuong M, et al. Functional relationship between mast cells and C-sensitive nerve fibres evidenced by $\mathrm{H} 3$-receptor modulation in rat lung and spleen. Clin Sci 1994; 87: 151-63.

[213] Hancock AA, Brune ME. Assessment of pharmacology and potential antiobesity properties of $\mathrm{H}_{3}$ receptor antagonists/inverse agonists. Exp Opin Invest Drugs 2005; 14: 223-41.

[214] Passani MB, Lin JS, Hancock A, Crochet S, Blandina P. The histamine $\mathrm{H}_{3}$ receptor as a nocel therapeutic target for cognitive and sleep disorders. Trends Pharmacol Sci 2004; 25: 618-25.

[215] Leurs R, Bakker RA, Timmerman H, de Esch IJ. The histamine $\mathrm{H}_{3}$ receptor: from gene cloning to $\mathrm{H} 3$ receptor drug. Nat Rev Drug Disc 2005; 4: 107-20.

[216] Teuscher C, Subramanian M, Noubade R, et al. Central histamine H3 receptor signaling negatively regulates susceptibility to autoimmune inflammatory disease of the CNS. Proc Natl Acad Sci USA 2007; 104: 10146-51.

[217] Drutel G, Peitsaro N, Karlstedt K, et al. Identification of rat H3 receptor isoforms with different brain expression and signaling properties. Mol Pharmacol 2001; 59: 1-8.

[218] Cogé F, Guénin SP, Audinot V, et al. Genomic organization and characterization of splice variants of the human histamine H3 receptor. Biochem J 2001; 355: 279-88.

[219] Wellendorph P, Goodman MW, Burstein ES, Nash NR, Brann MR, Weiner DM. Molecular cloning and pharmacology of functionally distinct isoforms of the human histamine $\mathrm{H}(3)$ receptor. Neuropharmacology 2002; 42: 929-40.

[220] Bongers G, Bakker RA, Leurs R. Molecular aspects of the histamine $\mathrm{H}_{3}$ receptor. Bio Pharmacol 2007; 73: 1195-204.

[221] Stark H. Histamine Receptors. Biotrends Rev 2007; 1: 2-9. [accessed Feb. 2008]. Available from: http: //www.biotrend.com

[222] Arrang JM, Garbarg M, Lancelot JC, et al. Highly potent and selective ligands for histamine. H3-receptors. Nature (Lond.) 1987; 327: 117-23.

[223] Arrang JM, Roy J, Morgat JL, Schunack W, Schwartz JC. Histamine $H 3$-receptor binding sites in rat brain membranes: modula- tions by guanine nucleotides and divalent cations. Eur J Pharmacol 1990; 188: 219-27.

[224] Pollard H, Moreau J, Arrang JM, Schwartz JC. A detailed autoradiographic mapping of histamine $H 3$-receptors in rat brain. Neuroscience 1993; 52: 169-89.

[225] Martinez-Mir MI, Pollard H, Moreau J, et al. Three histamine receptors $(\mathrm{H} 1, \mathrm{H} 2$ and $\mathrm{H} 3$ ) visualized in the brain of human and non-human primates. Brain Res 1990; 526: 322-7.

[226] Kilpatrick GJ, Michel AD. Characterisation of the binding of the histamine $H 3$-receptor agonist $[3 \mathrm{H}]{ }^{\circledR}-\alpha$-methyhistamine to homogenates of rat and guinea-pig cortex. Agents Actions 1991; 33: 69-75.

[227] Korte A, Myers J, Shih NY, Egan RW, Clark MA. Characterization and tissue distribution of $H 3$-receptors in guinea-pigs by $\mathrm{N \alpha}$ methylhistamine. Biochem Biophys Res Commun 1990; 168: 97986.

[228] Clark EA, Hill SJ. Differential effect of sodium ions and guanine nucleotides on the binding of thioperamide and clobenpropit to histamine $H 3$-receptors in rat cerebral cortical membranes. Br J Pharmacol 1995; 114: 357-62.

[229] Zweig A, Siegel MI, Egan RW, Clark MA, Shorr RGL, West RE. Characterization of a digitonin-solubilised bovine brain H3histamine receptor coupled to a guanine nucleotide-binding protein. J Neurochem 1992; 59: 1661-6.

[230] West RE, Jr, Zweig A, Shih NY, Siegel MI, Egan RW, Clark MA. Identification of two H3-histamine receptor subtypes. Mol Pharmacol 1990; 38: 610-3.

[231] Jansen FP, Rademaker B, Bast A, Timmerman H. The first radiolabeled histamine $H 3$ receptor antagonist, [125i]iodophenpropit: saturable and reversible binding to rat cortex membranes. Eur J Pharmacol 1992; 217: 203-5.

[232] Brown JD, O'Shaughnessy CT, Kilpatrick GJ, et al. Characterisation of the specific binding of the histamine $H 3$-receptor antagonist radioligand 3HGR16820. Br J Pharmacol 1994; 114: 344.

[233] Ligneau X, Garbarg M, Vizuete ML, et al. 125I-Iodoproxyfan, a new antagonist to label and visualize cerebal histamine H3receptors. J Pharmacol Exp Ther 1994; 271: 452-9.

[234] Alves-Rodrigues A, Leurs R, Tin-Seng WU, Prell GD, Foged C, Timmerman $\mathrm{H}$. 3H-Thioperamide as a radioligand for the histamine $H 3$ - receptor in rat cerebral cortex. Br J Pharmacol 1996; 118 2045-52.

[235] Arrang JM, Devaux B, Chodkiewicz JP, Schwartz JC. H3-receptors control histamine release in human brain. J Neurochem 1988; 51 : 105-8.

[236] Van der Werf JF, Timmerman H. The histamine H3-receptor: a general presynaptic histaminergic regulatory mechanism? Trends Pharmacol Sci 1989; 10: 159-62.

[237] Schlicker E, Fink K, Hinterhaner M, Göthert M. Inhibition of noradrenaline release in the rat brain cortex via presynaptic $H 3$ receptors. Naunyn-Schmiedeberg's Arch Pharmacol 1989; 340: 6338.

[238] Schlicker E, Behling A, Lummen G, Malinowska B, Göthert M Mutual interaction of histamine $H 3$-receptors and a2-adrenoceptors on noradrenergic terminals in mouse and rat brain cortex. NaunynSchmiedeberg's Arch Pharmacol 1992; 345: 639-6.

[239] Clapham J, Kilpatrick GJ. Histamine $H 3$ receptors modulate the release of $[3 \mathrm{H}]$-acetylcholine from slices of rat entorhinal cortex: evidence for the possible existence of $\mathrm{H3}$ receptor subtypes. $\mathrm{Br} \mathrm{J}$ Pharmacol 1992; 107: 919-23.

[240] Schlicker E, Fink K, Detzner M, Göthert M. Histamine inhibits dopamine release in the mouse striatum via presynaptic H3receptors. J Neural Transm 1993; 93: 1-10.

[241] Haas HL. Electrophysiology of histamine receptors, in The Histamine Receptor: Receptor Biochemistry and Methodology. In: Schwartz JC, Haas HL, Eds. Wiley-Liss, New York 1992; pp. 16177.

[242] Ishikawa S, Sperelakis N. A novel class (H3) of histamine receptors on perivascular nerve terminals. Nature (Lond) 1987; 327 158-160.

[243] Molderings GJ, Weibenborn G, Schlicker E, Likungu J, Göthert M Inhibition of noradrenaline release from the sympathetic nerves of the human saphenous vein by presynaptic histamine H3-receptors. Naunyn-Schmiedeberg's Arch Pharmacol 1992; 346: 46-50.

[244] Endou M, Poli E, Levi R. Histamine H3-receptor signalling in the heart: possible involvement of $\mathrm{Gi} / \mathrm{Go}$ proteins and N-type $\mathrm{Ca} 21$ channels. J Pharmacol Exp Ther 1994; 269: 221-9. 
[245] Imamura M, Poli E, Omoniyi AT, Levi R. Unmasking of activated histamine $H 3$-receptors in myocardial ischemia: their role as regulators of exocytotic norepinephrine release. J Pharmacol Exp Ther 1994; 271: 1259-66.

[246] Imamura M, Seyedi N, Lander HM, Levi R. Functional identification of histamine H3-receptors in the human heart. Circ Res 1995; 77: 206-10.

[247] Ichinose M, Belvisi MG, Barnes PJ. Histamine H3-receptors inhibit neurogenic microvascular leakage in airways. J Appl Physiol 1990; 68: 21-5

[248] Matsubara T, Moskowitz MA, Huang Z. UK 14,304, R(-)- $\alpha-$ methylhistamine, and Sms 201-995 block plasma protein leakage within dura mater by prejunctional mechanisms. Eur J Pharmacol 1992; 225: 145-50.

[249] Ohkubo T, Shibata M. ATP-sensitive K1 channels mediate regulation of substance $\mathrm{P}$ release via the prejunctional histamine $\mathrm{H} 3$ receptor. Eur J Pharmacol 1995; 277: 45-9.

[250] Imamura M, Smith NCE, Garbarg M, Levi R. Histamine H3- receptor-mediated inhibition of calcitonin gene-related peptide release from cardiac $\mathrm{C}$ fibers: a regulatory negative feedback loop. Circ Res 1996; 78: 863-9.

[251] Delaunois A, Gustin P, Garbarg M, Ansay M. Modulation of acetylcholine, capsaicin and substance $\mathrm{P}$ effects by histamine $\mathrm{H} 3 \mathrm{re}$ ceptors in isolated perfused rabbit lungs. Eur J Pharmacol 1995; 277: 243-50.

[252] Burgaud JL, Oudart N. NG-Nitro-L-arginine methyl ester inhibits the effect of an H3-histaminergic receptor agonist on Nanc contraction in guinea- pig perfused bronchioles. J Pharm Pharmacol 1994; 46: $153-5$.

[253] Taylor SJ, Kilpatrick GJ. Characterization of histamine- $H 3$ receptors controlling non-adrenergic non-cholinergic contractions of the guinea pig isolated ileum. Br J Pharmacol 1992; 105: 667-74

[254] Schworer H, Reimann A, Ramadori G, Rackẻ K. Characterization of histamine $H 3$-receptors inhibiting 5-HT release from porcine enterochromaffin cells: further evidence for $H 3$-receptor heterogeneity. Naunyn- Schmiedeberg's Arch Pharmacol 1994; 350: 375-9.

[255] Arrang JM, Drutel G, Schwartz JC. Characterization of histamine $H 3$-receptors regulating acetylcholine release in rat entorhinal cortex. Br J Pharmacol 1995; 114: 1518-22.

[256] Soldani G, Mengozzi G, Intorre L, De Giorgi G, Coruzzi G, Bertaccini G. Histamine $H 3$-receptor-mediated inhibition of gastric acid secretion in conscious dogs. Naunyn-Schmiedeberg's Arch Pharmacol 1993; 347: 61-5.

[257] Hollande F, Bali JP, Magous R. Autoregulation of histamine synthesis through $\mathrm{H3}$ receptors in isolated fundic mucosal cells. Am J Physiol 1993; 265: G1039-G44.

[258] Ea Kim L, Oudart N. A highly potent and selective $H 3$ agonist relaxes rabbit middle cerebral artery, in vitro. Eur J Pharmacol 1988; 150: 393-6.

[259] Ea Kim L, Javellaud J, Oudart N. Endothelium-dependent relaxation of rabbit middle cerebral artery to a histamine H3-agonist is reduced by inhibitors of nitric oxide and prostacyclin synthesis. $\mathrm{Br}$ J Pharmacol 1992; 105: 103-6.

[260] Clark MA, Korte A, Myers J, Egan RW. High affinity histamine H3 receptors regulate ACTH release by AtT-20 cells. Eur J Pharmacol 1992; 210: 31-5.

[261] Rouleau A, Ligneau X, Tardivel-Lacombe J, et al. Histamine H3receptor-mediated $[35 \mathrm{~S}] \mathrm{GTPg}[\mathrm{S}]$ binding: evidence for constitutive activity of the recombinant and native rat and human $\mathrm{H} 3$ receptors. Br J Pharmacol 2002; 135: 383-92.

[262] Morisset S, Rouleau A, Ligneau X, et al. High constitutive activity of native $\mathrm{H} 3$ receptors regulates histamine neurons in brain. Nature 2000; 408: 860-4.

[263] Takahashi K, Suwa H, Ishikawa T, Kotani H. Targeted disruption of $\mathrm{H} 3$ receptors results in changes in brain histamine tone leading to an obese phenotype. J Clin Invest 2002; 110: 1791-9.

[264] Cherifi Y, Pigeon C, Le Romancer M, Bado A, Reyl-Desmars F, Lewin MJM. Purification of histamine $H 3$ receptor negatively coupled to phosphoinositide turnover in the human gastric cell line HGT1. J Biol Chem 1992; 267: 25315-20.

[265] Jansen FP, Wu TS, Voss HP, et al. Characterization of the binding of the first selective radiolabeled histamine $H 3$-receptor antagonist, 125I-iodophenpropit, to rat brain. Br J Pharmacol 1994; 113: 35562.
[266] Clark EA, Hill SJ. Sensitivity of histamine $H 3$ receptor agoniststimulated [35S]-GTPgS binding to pertussis toxin. Eur J Pharmacol 1996; 296: 223-5.

[267] Schlicker E, Glaser T, Lümmen G, Neise A, Göthert M. Serotonin and histamine receptor-mediated inhibition of serotonin and noradrenaline release in rat brain cortex under nimodipine treatment. Neurochem Int 1991; 19: 437-44.

[268] Jablonowski JA, Carruthers NI, Thurmond RL. The histamine H4 receptor and potential therapeutic uses for $\mathrm{H} 4$ ligands. Mini-Rev Med Chem 2004; 4: 993-1000.

[269] Buckland KF, Williams TJ, Conroy DM. Histamine induced cytoskeletal changes in human eosinophils via the $\mathrm{H} 4$ receptor. $\mathrm{Br} \mathrm{J}$ Pharmacol 2003; 140: 1117-27.

[270] Gantner F, Sakai K, Tusche MW, Cruikshank WW, Center DM, Bacon KB. Histamine $\mathrm{H} 4$ and $\mathrm{H} 2$ receptors control histamineinduced interleukin-16 release from human $\mathrm{CD}^{8+} \mathrm{T}$ cells. J Pharmacol Exp 2002; 303: 300-7.

[271] Hofstra CL, Desai PJ, Thurmond RL, Fung-Leung WP. Histamine $\mathrm{H} 4$ receptor mediates chemotaxis and calcium mobilization of mast cells. J Pharmacol Exp Ther 2003; 305: 1212-21.

[272] O'Reilly M, Alpert R, Jenkinson S, et al. Identification of a histamine H4 receptor on human eosinophils. Role in eosinophil chemotaxis. J Recep Signal Transduct 2002; 22: 431-48.

[273] Nakamura T, Itadani H, Hidaka Y, Ohta M, Tanaka K. Molecular cloning and characterization of a new human histamine receptor, H4R. Biochem Biophys Res Commun 2000; 279: 615-20.

[274] Zhu Y, Michalovich D, Wu H, et al. Cloning, expression, and pharmacological characterization of a novel human histamine receptor. Mol Pharmacol 2001; 59: 434-41.

[275] Leurs R. Identification of rat H3 receptor isoforms with different brain expression and signaling properties. Mol Pharmacol 2001; 59: 1-8.

[276] Ling P, Ngo K, Nguyen S, et al. Histamine H4 receptor mediates eosinophils chemotaxis with cell shape change and adhesion upregulation. Br J Pharmacol 2004; 142: 161-7.

[277] Gutzmer R, Diestel C, Mommert S, et al. Histamine H4 receptor stimulation suppresses IL-12p70 production and mediates chemotaxis in human monocytes-derived dendritic cells. J Immunol 2005 174: 5224-32.

[278] Dijkstra D, Leurs R, Chazot P, et al. Histamine downregulates monocyte CCL2 production through the histamine H4 receptor. J Allergy Clin Immunol 2007; 120: 300-7.

[279] De Esch IJP, Thurmond RL, Jongejan A, Leurs R. The histamine $\mathrm{H} 4$ receptor as a new target for inflammation. Trends Pharmacol Sci 2005; 26: 462-9.

[280] Daugherty BL. Histamine H4 antagonism: a therapy for chronic allergy? Br J Pharmacol 2004; 142: 5-7.

[281] Thurmond RL, Desai PJ, Dunford PJ, et al. A potent and selective histamine $\mathrm{H} 4$ receptor antagonist with anti-inflammatory properties. J Pharmacol Exp Ther 2004; 309: 404-13.

[282] Thurmond RL, Gelfand EW, Dunford PJ. The role of histamine $\mathrm{H}_{1}$ and $\mathrm{H}_{4}$ receptors in allergic inflammation: the search for new antihistamines. Nat Rev Drug Discov 2008; 7: 41-53.

[283] Hough LB. Genomics meets histamine receptors: new subtypes, new receptors. Mol Pharmacol 2001; 59: 415-9.

[284] Liu C, Ma X-J, Jiang X, et al. Cloning and pharmacological characterization of a fourth histamine receptor (H4) expressed in bone marrow. Mol Pharmacol 2001; 59: 420-6.

[285] Nguyen T, Shapiro DA, George SR, et al. Discovery of a novel member of the histamine receptor family. Mol Pharmacol 2001; 59: 427-33.

[286] Cogé F, Guénin SP, Rique H, Boutin JA, Galizzi JP. Structure and expression of the human histamine H4-receptor gene. Biochem Biophys Res Commun 2001; 284: 301-9.

[287] Liu C, Wilson SJ, Kuel C, Lovenberg TW. Comparison of human, mouse, rat, and guinea pig histamine $\mathrm{H} 4$ receptors reveals substantial pharmacological species variation. J Pharmacol Exp Ther 2001; 299: 121-30.

[288] Morgan ET. Regulation of cytochrome P450 by inflammatory mediators: why and how. Drug Metab Dispos 2001; 29: 207-12.

[289] Mahnke A, Roos PH, Hanstein WG, Chabot GG. In vivo induction of cytochrome P450 CYP3A expression in rat leukocytes using various inducers. Biochem Pharmacol 1996; 51: 1579-82.

[290] Nebert DW, Russell DW. Clinical importance of the cytochrome P450. Lancet 2002; 360: 1155-62. 
[291] Brandes LJ, Queen GM, Labella FS. Displacement of histamine from liver cells and cell components by ligands for cytochrome P450. J Cell Biochem 2002; 85: 820-24.

[292] Labella FS, Brandes LJ. Interaction of histamine and other bioamines with cytochromes P450: implications for cell growth modulation and chemopotentiation by drugs. Semin Cancer Biol 2000; 10: 47-53.

[293] Bencsath M, Gidali J, Brandes LJ, Falus A. Murine and human hematopoietic colony formation: a possible regulatory role for intracellular histamine. Acta Biol Hung 2002; 53: 299-306.

[294] Brandes LJ, Queen GM, Labella FS. N,N-Diethyl-2-[4(phenylmethyl) phenoxy] ethanamide (DPPE), a chemopotentiating and cytoprotective agent in clinical trials: interaction with histamine at cytochrome P4503A4 and other isozymes that metabolize antineoplastic drugs. Cancer Chemother Pharmacol 2000; 45: 298304.

[295] Hamelin BA, Gouayad A, Drolet B, Gravel A, Turgeon J. In vitro characterization of cytochrome P450 2D6 inhibition by classic histamine H1 receptor antagonists. Drug Metab Dispos 1998; 26: 5369.

[296] Kishimoto W, Hiroi T, Sakai K, Fuane Y, Igarashi T. Metabolism of epinastine, a histamine $\mathrm{H} 1$ receptor antagonist, in human liver microsomes in comparison with that of terfenatine. Res Commun Chem Pathol Pharmacol 1997; 98: 273-92.

[297] Yang R, Hey JA, Aslanian R, Rizzo CA. Coordination of histamine $\mathrm{H} 3$ receptor antagonists with human adrenal cytochrome P450 enzymes. Pharmacology 2002; 66: 128-35.

[298] Tamasi V, Fulop AK, Egyi K, Monostory K, Falus A. Upregulation of cyp2e1 and cyp3a activities in histamine-deficient histidine decarboxylase gene targeted mice. Cell Biol Int 2003; 27: 1011-5.

[299] Erickson JD, Varoqui H. Molecular analysis of vesicular amine transporter function and targeting to secretory organelles. FASEB J 2000; 14: 2450-8.

[300] Watson F, Deavall DG, MacRo JA, Kiernan R, Dimaline R. Transcriptional activation of vesicular monoamine transporter 2 in the pre-B cell line Ea3.123. Biochem J 1999; 337: 193-9.

[301] Kazumori H, Ishihara S, Rumi MA, Ortega-Cava CF, Kadowaki Y, Kinoshita Y. Transforming growth factor alpha directly augments histidine decarboxylase and vesicular monoamine transporter 2 production in rat enterochromaffin-like cells. Am J Physiol Gastrointest Liver Physiol 2004; 286: 514.

[302] Travis ER, Wang YM, Michel DJ, Caron MG, Wightman RM. Differential quantal release of histamine and 50-hydroxytryptamine from mast cells of vesicular monoamine transporter 2 knockout mice. Proc Natl Acad Sci USA 2000; 97: 162-7.

[303] Gründemann D, Liebich G, Kiefer N, Köster S, Schömig E. Selective substrates for non-neuronal monoamine transporters. Mol Pharmacol 1999; 56: 1-10.

[304] Triggiani M, Gentile M, Secondo A, et al. Histamine induces exocytosis and IL-6 production from human lung macrophages through interaction with H1 receptors. J Immunol 2001; 166: 4083-91.

[305] Spitaler MM, Hammer A, Malli R, Graier WF. Functional analysis of histamine receptor subtypes involved in endotheliummediated relaxation of the human uterine artery. Clin Exp Pharmacol Physiol 2002; 29: 711-6.

[306] Sugimoto Y, Iba Y, Nakamura Y, Kayasuga R, Kamei C. Pruritusassociated response mediated by cutaneous $\mathrm{H} 3$ receptors. Clin Exp Allergy 2004; 34: 456-59.

[307] McLeod RL, Mingo GG, Herczku C, et al. Combined histamine H1 and $\mathrm{H} 3$ receptor blockade produces nasal decongestion in an experimental model of nasal congestion. Am J Rhinol 1999; 13: 3919.

[308] Lippert U, Artuc M, Grützkau A, et al. Human skin mast cells express $\mathrm{H} 2$ and H4, but not $\mathrm{H} 3$ receptors. J Invest Dermatol 2004; 123: 116-23.

[309] Godot V, Arock M, Garcia G, et al. H4 Histamine receptor mediates optimal migration of mast cell precursors to CXCL12. J Allergy Clin Immunol 2007; 120: 827-43.

[310] Ohtsu H, Tanaka S, Terui T, et al. Mice lacking histidine decarboxylase exhibit abnormal mast cells. FEBS Lett 2001; 502: 53-6.

[311] Ohtsu H, Kuramasu A, Tanaka S, et al. Plasma extravasation induced by dietary supplemented histamine in histamine-free mice. Eur J Immunol 2002; 32: 1698-708.

[312] Makabe-Kobayashi Y, Hori Y, Adachi T, et al. The control effect of histamine on body temperature and respiratory function in IgE- dependent systemic anaphylaxis. J Allergy Clin Immunol 2002; 110: 298-303.

[313] Schneider E, Lemoine FM, Breton-Gorius J, et al. IL-3-induced coexpression of histidine decarboxylase, IL-4, and IL- 6 mRNA by murine basophil precursors. Exp Hematol 1999; 27: 1010-8.

[314] Schneider E, Machavoine F, Pléau JM, et al. Organic cation transporter 3 modulates murine basophil functions by controlling intracellular histamine levels. J Exp Med 2005; 202: 387-93.

[315] Tanaka S, Deai K, Inagaki M, Ichikawa A. Uptake of histamine by mouse peritoneal macrophages and a macrophage cell line, RAW264.7. Am J Physiol Cell Physiol 2003; 285: C592-C8.

[316] Tedeschi A, Lorine M, Arquati M, Miadonna A. Regulation of histamine release from human basophil leukocytes role of $\mathrm{H} 1, \mathrm{H} 2$ and $\mathrm{H} 3$ receptors. Allergy 1991; 46: 626-31.

[317] Bull HA, Courtney PF, Bunker CB, Rustin MH, Pearce FL, Dowd PM. Basophil mediator release in atopic dermatitis. J Invest Dermatol 1993; 100: 305-9.

[318] Kleine-Tebbe J, Schramm J, Bolz M, Lipp R, Schunack W, Kunkel $\mathrm{G}$. Influence of histamine H3-anatgonists on human leukocytes. Agents Actions 1990; 30: 137-9.

[319] Lippert U, Moller A, Welker P, Artuc M, Henz BM. Inhibition of cytokine secretion from human leukemic mast cells and basophils by H1- and H2- receptor antagonists. Exp Dermatol 2000; 9: 11824.

[320] Sachs B, Hertl M, Merk HF. Histamine receptors on lymphocytes: distribution and functional significance. Skin Pharmacol Appl Skin Physiol 2000; 13: 313-23.

[321] Sansoni P, Silverman ED, Khan MM, Melmon KL, Engleman EG. Immunoregulatory $\mathrm{T}$ cells in man: histamine-induced suppressor $\mathrm{T}$ cells are derived from Leu 21 (T1) subpopulation distinct from that, which gives rise to cytotoxic T cells. J Clin Invest 1985; 75: 650-6.

[322] Khan MM, Marr-Leisy D, Verlander MS, et al. The effects of derivatives of histamine on natural suppressor cells. J Immunol 1986; 137: 308-14.

[323] Weltman JK. Update on histamine as a mediator of inflammation. Allergy Asthma Proc 2000; 3: 125-8.

[324] Elenkov I, Webster E, Papanicolaou DA, Fleisher TA, Chrousos GP, Wilder RL. Histamine potently suppresses human IL-12 and stimulates IL-10 production via H2 receptors. J Immunol 1998; 161: 2583-93.

[325] Arad G, Nussinovich R, Náamad M, Kaempfer R. Dual control of human interleukin-2 and interferon-gamma gene expression by histamine: activation and suppression. Cell Immunol 1996; 170: 14955 .

[326] Krouwels FH, Hol BEA, Lutter R, Bruinier B, Bast A. Histamine affects interleukin-4, interleukin-5, and interferon gamma by $\mathrm{T}$ cell clones from the airways and blood. Am J Respir Cell Mol Biol 1998; 18: 721-30.

[327] Osna N, Elliott K, Khan MM. Regulation of interleukin-10 secretion by histamine in Th2 cells and splenocytes. Int Immunopharmacol 2001; 1: 85-6.

[328] Osna N, Elliott K, Khan MM. The effects of histamine on interferon gamma production are dependent on the stimulatory signals. Int Immunopharmacol 2001; 1: 125-45.

[329] Elliott K, Osna N, Scofield M, Khan MM. Regulation of IL- 13 production by histamine in cloned murine T helper type 2 cells. Int Immunopharmacol 2001; 1: 1923-37.

[330] Sirois J, Menard G, Moses AS, Bissonnette EY. Importance of histamine in the cytokine network in the lung through $\mathrm{H} 2$ and $\mathrm{H} 3$ receptors: stimulation of IL-10 production. J Immunol 2000; 164 : 2964-70.

[331] Jutel M, Klunker S, Akdis M, et al. Histamine upregulates Th1 and downregulates Th2 responses due to different patterns of surface histamine 1 and 2 receptor expression. Int Arch Allergy Immunol 2001; 124: 190-2.

[332] Qui R, Melmon KL, Khan MM. Effects of histamine trifluoromethyl-toludine (HTMT) on intracellular calcium in human lymphocytes. J Pharmacol Exp Therap 1990; 253: 1245-52.

[333] Rocklin RE. Histamine and $\mathrm{H} 2$ Antagonists in Inflammation and Immunodeficiency. Marcel Dekker, New York 1990.

[334] Khan MM, Sansoni P, Engleman EG, Melmon KL. Pharmacological effects of autacoids on subsets of T cells: regulation of expression/ function of histamine-2 receptors by a subset of suppressor cells. J Clin Invest 1985; 75: 1578-83. 
[335] Khan MM, Melmon KL. Selected autacoids as modulators of lymphocyte function, in Handbook of experimental pharmacology, Springer-Verlag: Berlin, 1988, pp. 363-83.

[336] Khan MM, Melmon KL. Are autocoids more than theoretic modulators of immunity? Clin Immunol Rev 1985; 4: 1-30.

[337] Horváth BV, Szalai C, Mándi Y, et al. Histamine and histaminereceptor antagonists modify gene expression and biosynthesis of interferon gamma in peripheral human blood mononuclear cells and in CD19-depleted cell subsets. Immunol Lett 1999; 70: 95-9.

[338] Lagier B, Lebel B, Bousquet J, Pene J. Different modulation by histamine of IL-4 and interferon-gamma (IFN- $\gamma$ ) release according to the phenotype of human Th0, Th1 and Th2 clones. Clin Exp Immunol 1997; 108: 545-51.

[339] Center DM, Cruikshank WW, Berman JS, Beer DJ. Functional characteristics of histamine receptor-bearing mononuclear cells. I. Selective production of lymphocyte chemoattractant lymphokines with histamine as a ligand. J Immunol 1983; 131: 1854-9.

[340] Berman JS, Mcfadden RG, Cruikshank WW, Center DM, Beer DJ. Functional characteristics of histamine receptor-bearing mononuclear cells. II. Identification and characterization of two histamine induced lymphokines that inhibit lymphocyte migration. J Immunol 1984; 133: 1495-504.

[341] Westcott S, Kaliner M. Histamine H-1 binding site on human polymorphonuclear leukocytes. Inflammation 1983; 7: 291-300.

[342] Gespach C, Abita JP. Human polymorphonuclear neutrophils. Pharmacological characterisation of histamine receptors mediating the elevation of cyclic AMP. Mol Pharmacol 1982; 21: 78-85.

[343] Radermecker M, Maldague MP. Depression of neutrophil chemotaxis in atopic individuals: an $\mathrm{H} 2$ histamine receptor response. Int Arch allergy Appl Immunol 1981; 65: 144-52.

[344] Bury TB, Corhay JL, Radermecker MP. Histamine-induced inhibition of neutrophil chemotaxis and T-lymphocyte proliferation in man. Allergy 1992; 47: 624-9.

[345] Seligmann BE, Fletcher MP, Gallin JI. Histamine modulation of human neutrophil oxidative metabolism, locomotion, degranulation, and membrane potential changes. J Immunol 1983; 130: 19029.

[346] Burde R, Seifert R, Buschauer A, Schultz G. Histamine inhibits activation of human neutrophils and HL-60 leukemic cells via H2receptors. Naunyn-Schmiedebergs Arch Pharmacol 1983; 340: 671-8.

[347] Wang KY, Arima N, Higuchi S, et al. Switch of histamine receptor expression from $\mathrm{H} 2$ to $\mathrm{H} 1$ during differentiation of monocytes into macrophages. FEBS Lett 2000; 473: 345-8.

[348] Pynaert G, Grooten J, Vab Deventer SJ, Pepplenbosch MP. Cysteinyl leukotrienes mediate histamine hypersensitivity ex-vivo by increasing histamine receptor numbers. Mol Med 1999; 5: 685-92.

[349] Atkins PC, Schwartz LB, Adkinson NF, Von Allmen C, Valenzano $\mathrm{M}$, Zweiman B. In vivo antigen-induced cutaneous mediator release. Simultaneous comparisons of histamine, tryptase and prostaglandin D2 release and the effect of oral corticosteroid administration. J Allergy Clin Immunol 1990; 86: 360-70.

[350] Atkins PC, Von Allmen C, Valenzano M, Olson R, Shalit M, Zweiman B. Determinants of in vivo histamine release in cutaneous allergic reactions in humans. J Allergy Clin Immunol 1990; 86: 371-9.

[351] Marmy N, Mottas J, Durand J. Signal transduction in smooth muscle cells from human airways. Respir Physiol 1993; 91: 295-306.

[352] Jarjour NN, Calhoun WJ, Schwartz LB, Busse WW. Elevated bronchoalveolar lavage fluid histamine levels in allergic asthmatics are associated with increased airway obstruction. Am Rev Respir Dis 1991; 144: 83-7.

[353] Gutzmer R, Langer K, Lisewski M, et al. Expression and function of histamine receptors 1 and 2 on human monocyte-derived dendritic cells. J Allergy Clin Immunol 2002; 109: 524-31.

[354] Idzko M, La Sala A, Ferrari D, et al. Expression and function of histamine receptors in human monocyte-derived dendritic cells. J Allergy Clin Immunol 2002; 109: 839-46.

[355] Mazzoni A, Young HA, Spitzer JH, Visintin A, Segal DM. Histamine regulates cytokine production in maturing dendritic cells, resulting in altered T cell polarization. J Clin Invest 2001; 108: 186573.

[356] Morichika T, Takahashi HK, Iwagaki H, et al. Histamine inhibits lipopolysaccharide-induced tumor necrosis factor-alpha production in an intercellular adhesion molecule-1- and B7.1-dependent manner. J Pharmacol Exp Ther 2003; 304: 624-33.
[357] Ohtani T, Aiba S, Mizuashi M, Mollah ZU, Nakagawa S, Tagami $\mathrm{H}$. $\mathrm{H} 1$ and $\mathrm{H} 2$ histamine receptors are absent on Langerhans cells and present on dermal dendritic cells. J Invest Dermatol 2003; 121: 1073-9.

[358] Raible DG, Lenahan T, Fayvilevich Y, Kosinski R, Schulman ES. Pharmacological characterization of a novel histamine receptor on human eosinophils. Am J Respir Crit Care Med 1994; 149: 150611.

[359] Anwar AR, Kay AB. H1-receptor dependence of histamineinduced enhancement of human eosinophil $\mathrm{C} 3 \mathrm{~b}$ rosettes. Clin Exp Immunol 1980; 42: 196-9.

[360] Ezeamuzie CI, Philips E. Histamine H (2) receptors mediate the inhibitory effect of histamine on human eosinophil degranulation. Br J Pharmacol 2000; 131: 482-8.

[361] Jarjour NN, Sedgwick JB, Swensen CA, Busse WW. Late allergic airway response to segmental bronchopulmonary provocation in allergic subjects is related to blood basophil histamine release. J Allergy Clin Immunol 1997; 99: 87-93.

[362] Devalia JL, Davies RJ. Human nasal and bronchial epithelial cells in culture. An overview of their characteristics and function. Allergy Proc 1991; 12: 71-9.

[363] Sharif NA, Xu SX, Magnino PE, Pang IH. Human conjunctival epithelial cells express Histamine-1 receptors coupled to phosphoinositide turnover and intracellular calcium mobilisation. Role in ocular allergic and inflammatory diseases. Exp Eye Res 1996; 63: 169-78

[364] Hamano N, Terada N, Maesako K, et al. Expression of histamine receptors in nasal epithelial cells and endothelial cells-the effects of sex hormones. Int Arch Allergy Immunol 1998; 115: 220-7.

[365] Devalia JL, Wang JH, Davies RJ. Airway epithelial cells, in Cellular Mechanisms in Airway Inflammation. In: Page CP, Banner KH Spina D, Eds. Birkhäuser-Verlag, Basel 2000; pp. 245-62.

[366] Devalia JL, Rusznak C, Davies RJ. Epithelial cell dysfunction in rhinitis, in Asthma and Rhinitis. In: Busse WW, Holgate ST, Eds. Blackwell Science Ltd., London 2000, pp. 841-54.

[367] Aoki Y, Qiu D, Zhao GH, Kao PN. Leukotriene B4 mediates histamine induction of NF-kB and IL-8 in human bronchial epithelial cells. Am J Physiol-Lung Cell Mol Physiol 1998; 2746: L1030-L9.

[368] Yanni JM, Weimer LK, Sharif NA, Xu SX. Gamache DA, Spellman JM. Inhibition of histamine-induced human conjunctival epithelial cell responses by ocular allergy drugs. Arch Opthalmol 1999; 117: 643-7.

[369] Burke-Gaffney A, Hellewell PG. Contribution of endothelial cells to airway inflammation, in Cellular Mechanisms in Airway Inflammation. In: Page CP, Banner KH, Spina B, Eds. BirkhäuserVerlag, Basel 2000; pp. 223-244.

[370] Koizumi H, Ohkawara A. H2 histamine receptor-mediated increase in cultured human keratinocytes. J Dermatol Sci 1999; 21: 127-32.

[371] Schaefer U, Schmitz V, Schneider A, Neugebauer E. Histamineinduced homologous and heterologous regulation of histamine receptor subtype mRNA in cultured endothelial cells. Shock 1999; 12: 309-15.

[372] Farber HW, Weller PF, Rounds S, Beer DJ, Center DM. Generation of lipid neutrophil chemoattractant activity by histaminestimulated cultured endothelial cells. J Immunol 1986; 137: 291824.

[373] Vannier E, Miller LC, Dinarello CA. Histamine suppresses gene expression and synthesis of tumor necrosis factor alpha via histamine H2 receptors. J Exp Med 1991; 174: 281-4.

[374] Van der Pouw Kraan TC, Snijders A, Boeije LC, et al. Histamine inhibits the production of interleukin-12 through interaction with H2 receptors. J Clin Invest 1998; 102: 1866-73.

[375] Kohka H, Nishibori M, Iwagaki H, et al. Histamine is a potent inducer of IL-18 and IFN- $\gamma$ in human peripheral blood mononuclear cells. J Immunol 2000; 164: 6640-6.

[376] Carlsson R, Dohlsten M, Sjogren HO. Histamine modulates the production of interferon-gamma and interleukin-2 by mitogenactivated human mononuclear blood cells. Cell Immunol 1985; 96(1): 104-12.

[377] Vannier E, Dinarello CA. Histamine enhances interleukin (IL)-1induced IL-6 gene expression and protein synthesis via $\mathrm{H} 2$ receptors in peripheral blood mononuclear cells. J Biol Chem 1994; 269: 9952-6.

[378] Cameron W, Doyle K, Rocklin RE. Histamine type I (H1)-receptor radioligand binding studies on normal $\mathrm{T}$ cell subsets, $\mathrm{B}$ cells, and monocytes. J Immunol 1986; 136: 2116-20. 
[379] Liu MC, Bleecker ER, Lichtenstein LM, et al. Evidence for elevated levels of histamine, prostaglandin D2, and other bronchoconstricting prostaglandins in the airways of subjects with mild asthma. Am Rev Respir Dis 1990; 142: 126-32.

[380] Triggiani M, De Marino V, Sofia M, et al. Characterization of platelet-activating factor acetylhydrolase in human bronchoalveolar lavage. Am J Respir Crit Care Med 1997; 156: 94-100.

[381] Ganellin CR. Pharmacochemistry of H1- and H2-receptors. WileyLiss, New York 1992.

[382] Quintana FJ, Buzas E, Prohászka Z, et al. Modifying histamine production via knocking out of the histidine decarboxylase gene changes the repertoire of natural autoantibodies. J Autoimmun 2004; 22: 297.

[383] Tisch R, Yang XD, Singer SM, Liblau RS, Fugger L, McDevitt HO. Immune response to glutamic acid decarboxylase correlates with insulitis in non-obese diabetic mice. Nature 1993; 366: 72.

[384] Hide M, Francis DM, Grattan CEH, Hakimi J, Kochan JP, Greaves MW. Autoantibodies against the high-affinity $\operatorname{IgE}$ receptor as a cause of histamine release in chronic urticaria. N Engl J Med 1993; 328: 1599-604.

[385] Sabroe RA, Seed PT, Francis DM, Barr RM, Black AK, Greaves MW. Chronic idiopathic urticaria: comparison of the clinical features of patients with and without anti-FceRI or anti-IgE autoantibodies. J Am Acad Dermatol 1999; 40: 443-50.

[386] Grattan CEH, Francis DM, Slater NGP, Barlow RJ, Greaves MW. Plasmapheresis for severe, unremitting, chronic urticaria. Lancet 1992; 339: 1078-80.

[387] Slater JW, Zechnich AD, Haxby DG. Second-generation antihistamines: a comparative review. Drugs 1999; 57: 31-47.

[388] Sehra S, Barbé-Tuana FM, Holbreich M, Mousdicas N, Kaplan $\mathrm{MH}$, Travers JB. Clinical correlations of recent developments in the pathogenesis of atopic dermatitis. An Bras Dermatol 2008; 83(1): 57-73.
[389] Williams H, Robertson C, Stewart A, et al. Worldwide variations in the prevalence of symptoms of atopic eczema in the International Study of Asthma and Allergies in Childhood. J Allergy Clin Immunol 1999; 103 (Pt 1): 125-38.

[390] Di Tullio G. II Ruolo delle intolleranze alimentary nella etiopatogenesi della dermatite atopica. La Med Biol 2001; Oct-Dec: 103 10 .

[391] Gustafsson D, Sjoberg O, Foucard T. Development of allergies and asthma in infants and young children with atopic dermatitis-a prospective follow-up to 7 years of age. Allergy 2000; 55: 240-5.

[392] Spergel JM, Paller AS. Atopic dermatitis and the atopic march. J Allergy Clin Immunol 2003; 112(Suppl 6): S118-S27.

[393] Kemp AS. Cost of illness of atopic dermatitis in children: a societal perspective. Pharmacoeconomics 2003; 21: 105-13.

[394] Falus A, Hegyesi H, Lázár-Molnár E, Pós Z, László V, Darvas Z. Paracrine and autocrine interactions in melanoma: histamine is a relevant player in local regulation. Trends Immunol 2001; 22: 64852.

[395] Byron JW. Mechanism for histamine H2-receptor induced cellcycle changes in the bone marrow stem cell. Agents Actions 1977; 7: 209-13.

[396] Nakaya N, Tasaka K. The influence of histamine on precursor of granulocytic leukocytes in murine bone marrow. Life Sci 1999; 42: 999-1010.

[397] Moharana AK, Bhattacharya SK, Mediratta PK, Sharma KK. Possible role of histamine receptors in the central regulation of immune responses. Indian J Physiol Pharmacol 2000; 44: 153-60.

[398] Tripathi T, Shahid M, Siddiqui MU, Khan RA. Role and immunomodulatory profile of histamine receptors by $\mathrm{H} 1$ and $\mathrm{H} 2$ antagonists. Available from: Nature Precedings 2008. <http: //hdl.handle. net/10101/npre.2008.1547.1> (2008).

[399] Simons FER. Advances in H1-Antihistamines. N Engl J Med 2004; 351: 2203-17.

(c) Shahid et al.; Licensee Bentham Open.

This is an open access article licensed under the terms of the Creative Commons Attribution Non-Commercial License (http: //creativecommons.org/licenses/by$\mathrm{nc} / 3.0 /$ ) which permits unrestricted, non-commercial use, distribution and reproduction in any medium, provided the work is properly cited. 